\title{
ÆUSGS
}

Eusters

National Water-Quality Assessment Program

\section{Water Quality in the High Plains Aquifer, Colorado, Kansas, Nebraska, New Mexico, Oklahoma, South Dakota, Texas, and Wyoming, 1999-2004}

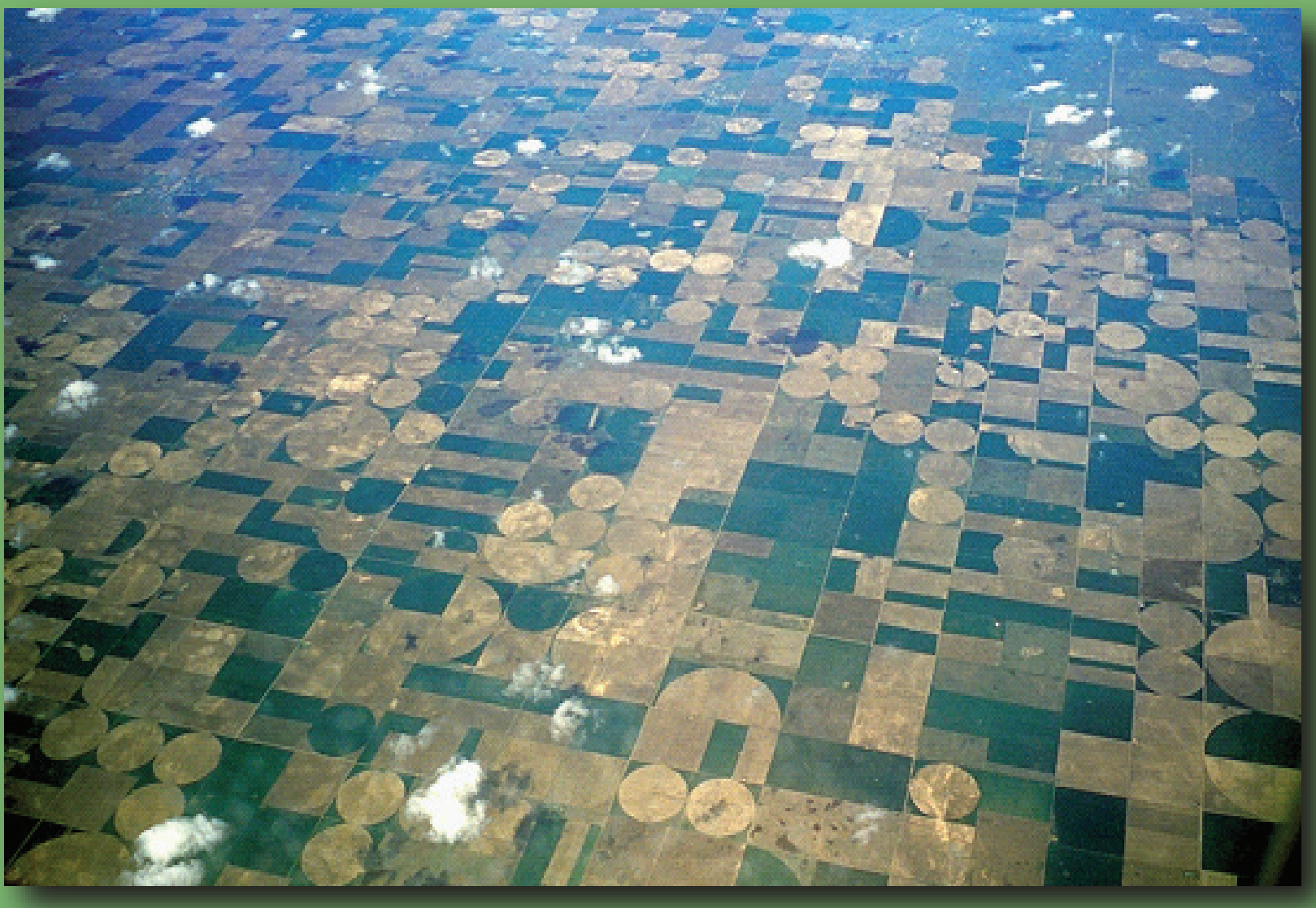

Circular 1337

U.S. Department of the Interior

U.S. Geological Survey 


\section{Points of Contact and Additional Information}

The companion Web site for NAWQA reports:

http://water.usgs.gov/nawqa/nawqa_sumr.htm/

High Plains Regional Groundwater Study contact and Web site:

USGS State Representative

U.S. Geological Survey

Colorado Water Science Center

Denver Federal Center, M.S. 415

Denver, CO 80225

http://co.water.usgs.gov/nawqa/hpgw/HPGW_home.html

National Water-Quality Assessment (NAWQA) Program:

Chief, NAWQA Program

U.S. Geological Survey

Water Resources Discipline

12201 Sunrise Valley Drive, M.S. 413

Reston, VA 20192

http://water.usgs.gov/nawqa/ 


\section{Water Quality in the High Plains Aquifer, Colorado, Kansas, Nebraska, New Mexico, Oklahoma, South Dakota, Texas, and Wyoming, 1999-2004}

By Jason J. Gurdak, Peter B. McMahon, Kevin Dennehy, and Sharon L. Qi

Circular 1337 


\title{
U.S. Department of the Interior \\ KEN SALAZAR, Secretary \\ U.S. Geological Survey \\ Suzette Kimball, Acting Director
}

\section{U.S. Geological Survey, Reston, Virginia: 2009}

\author{
For more information on the USGS — the Federal source for science about the Earth, its natural and living resources, \\ natural hazards, and the environment, visit http://www.usgs.gov or call 1-888-ASK-USGS \\ For an overview of USGS information products, including maps, imagery, and publications, \\ visit http://www.usgs.gov/pubprod \\ To order this and other USGS information products, visit http://store.usgs.gov
}

Any use of trade, product, or firm names is for descriptive purposes only and does not imply endorsement by the U.S. Government.

Although this report is in the public domain, permission must be secured from the individual copyright owners to reproduce any copyrighted materials contained within this report.

Suggested citation: Gurdak, J.J., McMahon, P.B., Dennehy, K.F., and Qi, S.L., 2009, Water quality in the High Plains aquifer, Colorado, Kansas, Nebraska, New Mexico, Oklahoma, South Dakota, Texas, and Wyoming, 1999-2004: U.S. Geological Survey Circular 1337, 63 p. 
"The rigorous scientific approach of the USGS NAWQA Program and the resulting improved understanding of groundwater quality in the High Plains aquifer will be invaluable for local and statewide management toward sustainable groundwater resources of this important aquifer system." 


\section{Foreword}

The U.S. Geological Survey (USGS) is committed to providing the Nation with credible scientific information that helps to enhance and protect the overall quality of life and that facilitates effective management of water, biological, energy, and mineral resources (http://www.usgs.gov/). Information on the Nation's water resources is critical to ensuring longterm availability of water that is safe for drinking and recreation and is suitable for industry, irrigation, and fish and wildlife. Population growth and increasing demands for water make the availability of that water, now measured in terms of quantity and quality, even more essential to the long-term sustainability of our communities and ecosystems.

The USGS implemented the National Water-Quality Assessment (NAWOA) Program in 1991 to support national, regional, State, and local information needs and decisions related to water-quality management and policy (http://water.usgs.gov/nawqa). The NAWQA Program is designed to answer: What is the condition of our Nation's streams and groundwater? How are conditions changing over time? How do natural features and human activities affect the quality of streams and groundwater, and where are those effects most pronounced? By combining information on water chemistry, physical characteristics, stream habitat, and aquatic life, the NAWQA Program aims to provide science-based insights for current and emerging water issues and priorities. From 1991-2001, the NAWQA Program completed interdisciplinary assessments and established a baseline understanding of water-quality conditions in 51 of the Nation's river basins and aquifers, referred to as Study Units (http://water.usgs.gov/nawqa/studyu.html).

In the second decade of the Program (2001-2012), a major focus is on regional assessments of water-quality conditions and trends. These regional assessments are based on major river basins and principal and other aquifers, which encompass larger regions of the country than the Study Units. Regional assessments extend the findings in the Study Units by filling critical gaps in characterizing the quality of surface water and ground water, and by determining status and trends at sites that have been consistently monitored for more than a decade. In addition, the regional assessments continue to build an understanding of how natural features and human activities affect water quality. Many of the regional assessments employ modeling and other scientific tools, developed on the basis of data collected at individual sites, to help extend knowledge of water quality to unmonitored, yet comparable, areas within the regions. The models thereby enhance the value of our existing data and our understanding of the hydrologic system. In addition, the models are useful in evaluating various resource-management scenarios and in predicting how our actions, such as reducing or managing nonpoint and point sources of contamination, land conversion, and altering flow and (or) pumping regimes, are likely to affect water conditions within a region. Other activities planned during the second decade include continuing national syntheses of information on pesticides, volatile organic compounds (VOCs), nutrients, selected trace elements, and aquatic ecology; and continuing national topical studies on the fate of agricultural chemicals, effects of urbanization on stream ecosystems, bioaccumulation of mercury in stream ecosystems, effects of nutrient enrichment on stream ecosystems, and transport of contaminants to public-supply wells. 


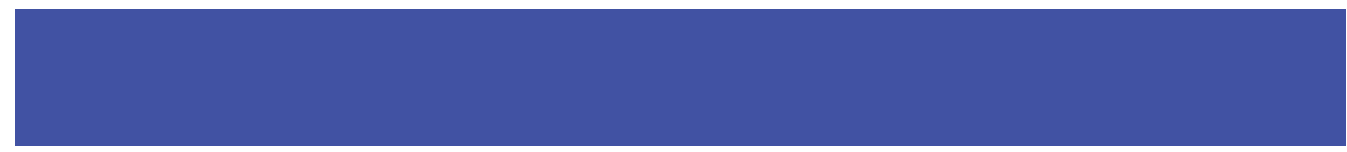

The USGS aims to disseminate credible, timely, and relevant science information to address practical and effective water-resource management and strategies that protect and restore water quality. We hope this NAWQA publication will provide you with insights and information to meet your needs, and will foster increased citizen awareness and involvement in the protection and restoration of our Nation's waters. The USGS recognizes that a national assessment by a single program cannot address all water-resource issues of interest. External coordination at all levels is critical for cost-effective management, regulation, and conservation of our Nation's water resources. The NAWQA Program, therefore, depends on advice and information from other agencies - Federal, State, regional, interstate, Tribal, and local—as well as nongovernmental organizations, industry, academia, and other stakeholder groups. Your assistance and suggestions are greatly appreciated.

Matthew C. Larsen, USGS Associate Director for Water

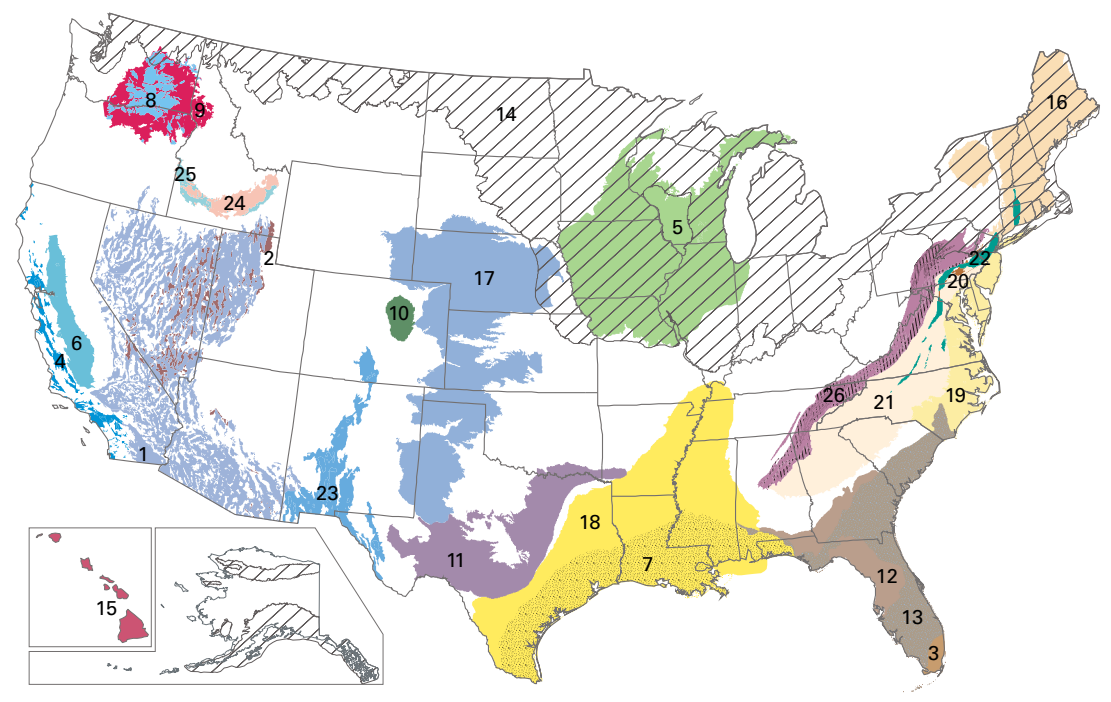

EXPLANATION

Basin and Range

1 Basin-fill aquifers

2 Carbonate-rock aquifers

3 Biscayne aquifer

4 California Coastal Basin aquifers

5 Cambrian-Ordovician aquifer system

6 Central Valley aquifer system

7 Coastal Lowlands aquifer system Columbia Plateau

8 Basin-fill aquifers

9 Basaltic-rock aquifers

10 Denver Basin aquifer system

11 Edwards-Trinity aquifer system

12 Floridan aquifer system

13 Surficial aquifer system (overlying the Floridan)

14. Glacial aquifer system
15 Hawaiian volcanic-rock aquifers-Locally overlain by sedimentary deposits

16 New England crystalline-rock aquifers

17 High Plains aquifer

18 Mississippi Embayment-Texas Coastal Uplands aquifer system

19 Northern Atlantic Coastal Plain aquifer system Piedmont and Blue Ridge

20 Carbonate-rock aquifers

21 Crystalline-rock aquifers

22 Early Mesozoic aquifers

23 Rio Grande aquifer system Snake River Plain

24 Basaltic-rock aquifers

25 Basin-fill aquifers

26 Valley and Ridge aquifers-Carbonate-rock aquifers are patterned

Figure 1. Locations of NAWOA regional assessments in principal (or other) aquifers. 


\section{Contents}

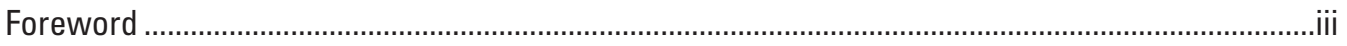

Introduction to this Report ............................................................................................................ii

Chapter 1 - Overview of Major Findings and Implications...........................................................1

Chapter 2 - Background on the Water Resource Beneath the High Plains....................................7

Chapter 3 - NAWQA Approach to Assessing Water Quality in the High Plains Aquifer...............13

Chapter 4 - Quality of Water Near the Water Table-What Was Found, Where, and Why ........18

Chapter 5 - Natural Processes and Human Activities Affecting the Quality of the Water as it Moves From the Water Table to the Resource Used for Drinking and Irrigation.........30

Chapter 6 - Quality of the Resource Used for Drinking and Irrigation-What Was Found,

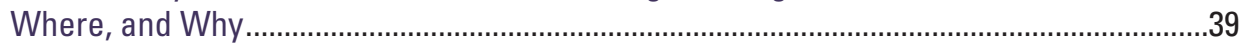

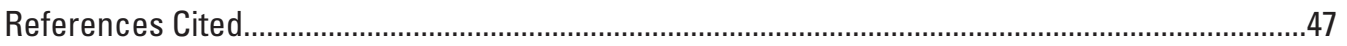

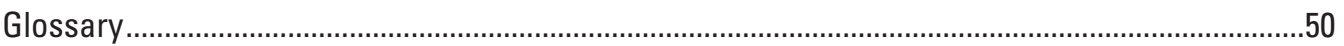

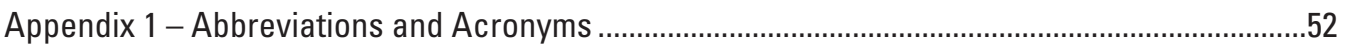

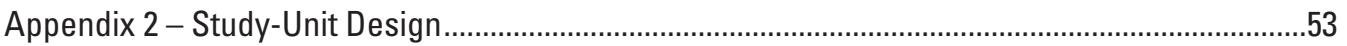

Appendix 3 - High Plains Findings in a National Context ...........................................................58

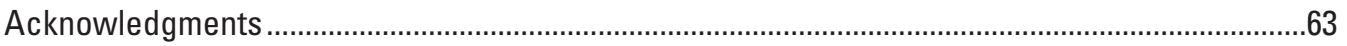

\section{Boxes}

A-Unique Features of the NAWQA Approach..................................................................14

$B$ - How Stable Isotopes Provide Insight Into the Sources and Sinks of Nitrate in the Aquifer.

C-Understanding Vertical Directions of Water Movement in the Aquifer using Groundwater-Level Measurements.

D-Short Circuiting of Multiscreened Wells Increases Groundwater Vulnerability to Contamination. 


\section{Introduction to this Report}

This report contains the major findings of a 1999-2004 assessment of water quality in the High Plains aquifer. It is one of a series of reports by the National Water-Quality Assessment (NAWQA) Program that present major findings for principal and other aquifers and major river basins across the Nation. In these reports, water quality is discussed in terms of local, regional, State, and national issues. Conditions in the aquifer system are compared to conditions found elsewhere and to selected national benchmarks, such as those for drinking-water quality.

This report is intended for individuals working with water-resource issues in Federal, State, or local agencies, universities, public interest groups, or the private sector. The information will be useful in addressing a number of current issues, such as drinking-water quality, the effects of agricultural practices on water quality, source-water protection, and monitoring and sampling strategies. This report is also for individuals who wish to know more about the quality of ground water in areas near where they live and how that water quality compares to the quality of water in other areas across the region and the Nation.

The water-quality conditions in the High Plains aquifer summarized in this report are discussed in greater detail in other reports that can be accessed in Appendix 1 of http://pubs.usgs.gov/pp/1749/. Detailed technical information, data and analyses, collection and analytical methodology, models, graphs, and maps that support the findings presented in this report in addition to reports in this series from other basins can be accessed from the national NAWQA Web site (http://water.usgs.gov/nawqa). This report accompanies the detailed and technical report of water-quality conditions in the High Plains aquifer "Waterquality assessment of the High Plains aquifer, 1999-2004"

(http://pubs.usgs.gov/pp/1749/).

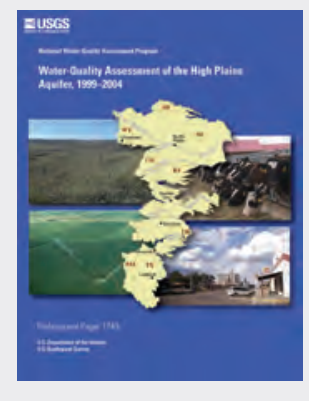

Detailed description of water quality in the High Plains aquifer from 1999 to 2004 is in the following report:

Water-quality assessment of the High Plains aquifer, 1999-2004

by P.B. McMahon, K.F. Dennehy, B.W. Bruce, J.J. Gurdak, and S.L. Qi:

U.S. Geological Survey Professional Paper 1749 available at http://pubs.usgs.gov/pp/1749/ 


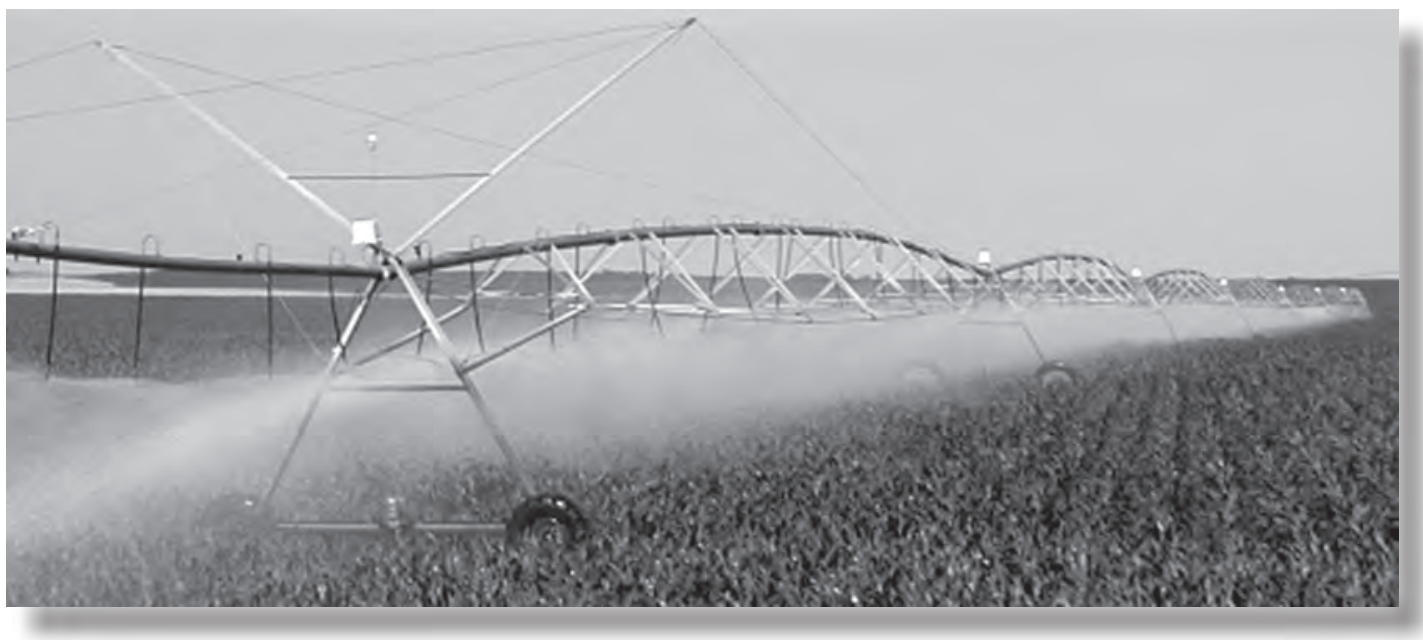

Irrigated agriculture is the dominant use of groundwater from the High Plains aquifer and can have substantial effects on groundwater quantity and quality in this important aquifer system. (Photograph by Jason J. Gurdak, USGS.) 


\section{Overview of Major Findings and Implications}

The NAWQA assessment of water-quality conditions of the High Plains aquifer for the period 1999-2004 provides the first systematic and comprehensive regional assessment of water quality in this nationally important aquifer. NAWQA results show where, when, why, and how specific water-quality conditions occur in groundwater across the High Plains aquifer and yield science-based implications for assessing and managing the quality of this water resource. Understanding groundwater quality conditions and the natural and human factors that control water quality in this aquifer is important because of the implications to human health, the sustainability of rural agricultural economies, and the substantial costs associated with land and water management, conservation, and regulation.

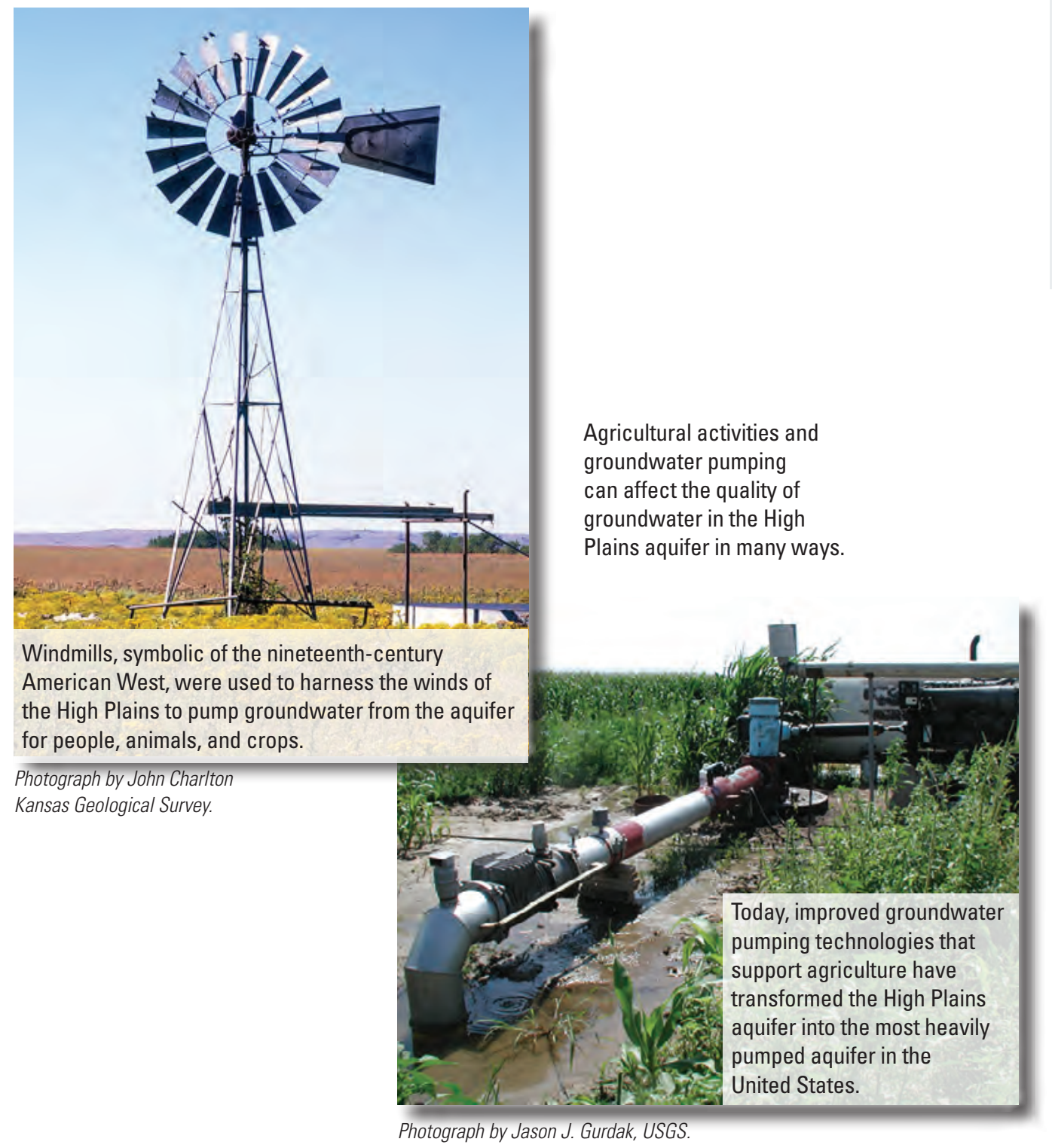
groundwater pumping can affect the quality of groundwater in the High Plains aquifer in many ways.
Agricultural activities and
This chapter provides a broad overview of NAWQA findings about the occurrence and distribution, trends, and factors controlling water-quality conditions in the High Plains aquifer and summarizes the major implications of these findings for waterquality assessment and management. Detailed discussions of each major topic are provided in subsequent chapters. 


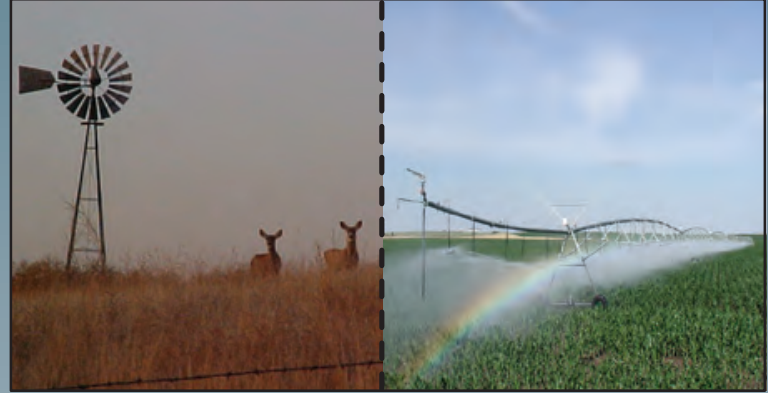

Conversion of rangeland to irrigated cropland affects groundwater quality - Irrigation enhances recharge in this semiarid area and has altered the quality of water recharging the aquifer by increasing the transport of agricultural chemicals and natural salt deposits to the water table. Concentrations of dissolved solids, nitrate, pesticides, and other constituents were elevated at the water table, reflecting the change in quality of recharge in areas converted from rangeland to cropland with applied agricultural chemicals. See Chapter 4.

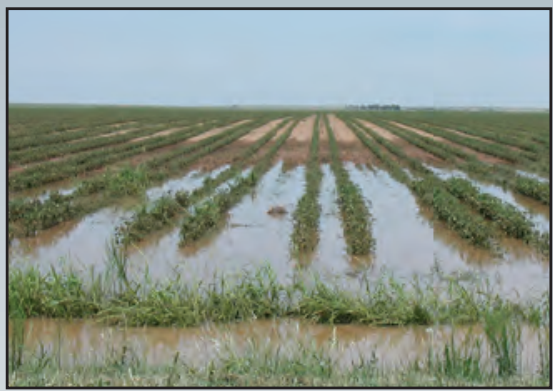

\section{Chemical transport to the water table follows fast}

and slow paths - Throughout much of the High Plains aquifer, the transport of chemicals from the land surface to the water table is slow, taking from decades to centuries. However, local variations in rates of chemical transport do occur, such as beneath natural depressions in the land surface that collect precipitation and return flow from irrigated fields, which can reduce the transport time of chemicals to the water table to months or years. See Chapter 4.

\section{Overview of Major Findings}

Availability and sustainability of groundwater in the High Plains aquifer are a function of water quantity and quality The High Plains aquifer underlies parts of eight States and is one of the largest aquifers in the world. The current availability and future sustainability of a high-quality groundwater supply is central to the overall health of the High Plains agricultural economy, viability of its cities and rural communities, and environmental well-being of the landscape. Use of the High Plains aquifer for irrigation water has transformed this area into an important agricultural region that sustains more than one-fourth of the Nation's agricultural production.
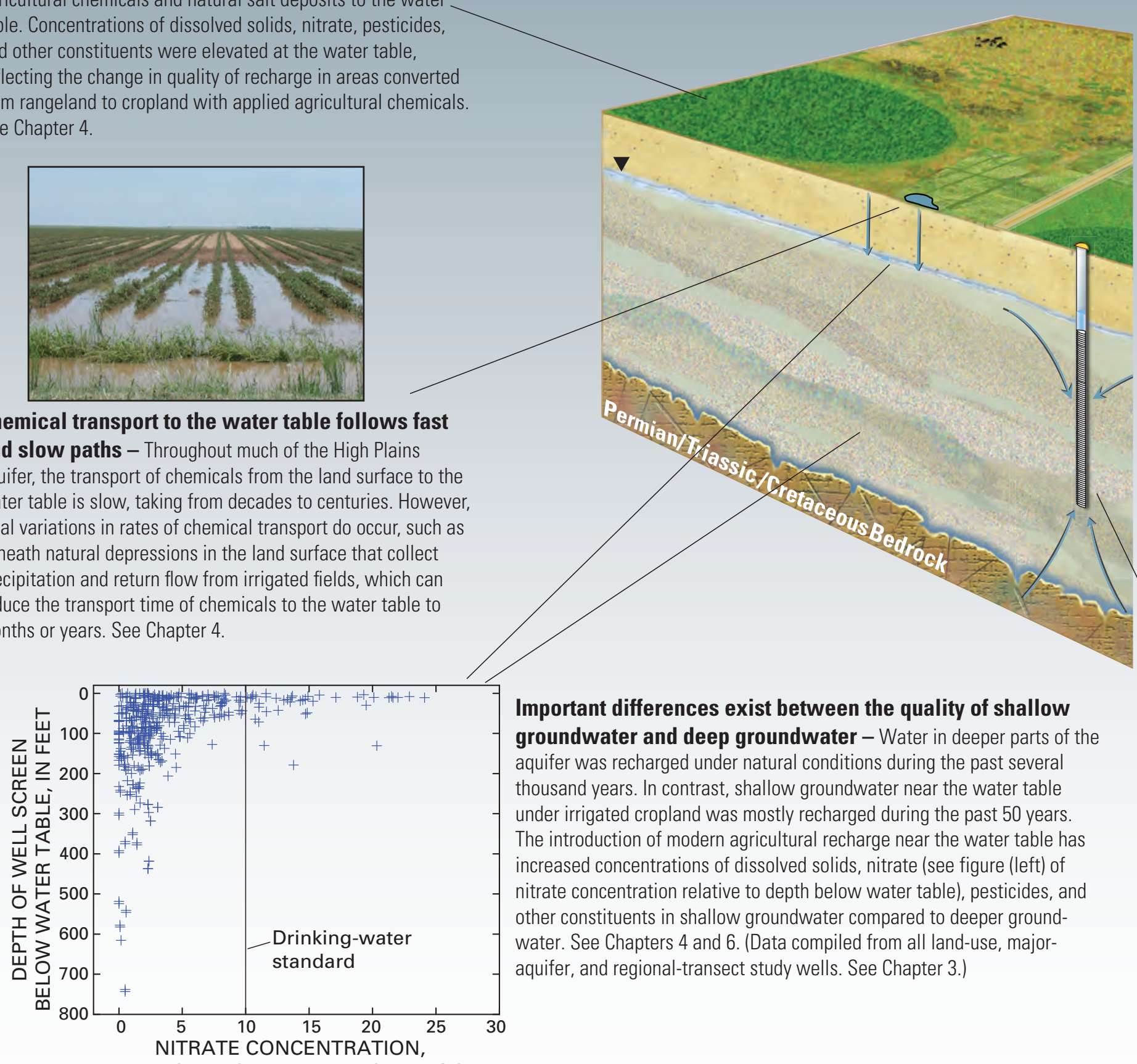

Important differences exist between the quality of shallow groundwater and deep groundwater - Water in deeper parts of the aquifer was recharged under natural conditions during the past several thousand years. In contrast, shallow groundwater near the water table under irrigated cropland was mostly recharged during the past 50 years. The introduction of modern agricultural recharge near the water table has increased concentrations of dissolved solids, nitrate (see figure (left) of nitrate concentration relative to depth below water table), pesticides, and other constituents in shallow groundwater compared to deeper groundwater. See Chapters 4 and 6. (Data compiled from all land-use, majoraquifer, and regional-transect study wells. See Chapter 3.) 


\section{Availability and Sustainability of Groundwater in the High Plains Aquifer are a Function of Water Quantity and Quality}

Groundwater is the primary source of water used in the High Plains; thus, knowledge about groundwater availability and sustainability are essential for the informed management of this limited resource. Groundwater availability and sustainability are functions of many factors, one of which is water quality. Understanding groundwater quality is important because it directly affects how water can be used. Water quality generally has been overlooked in the High Plains because the primary focus has been on obtaining a sufficient water supply, and it has been broadly assumed that the aquifer contains high-quality water. For the most part, results from the NAWQA study support that assumption. See Chapters 4, 5, and 6 for more details.

\section{Implications}

- Groundwater quality, particularly regarding elevated nitrate or dissolved-solids concentrations, may be a limiting factor for some intended uses such as drinking- or irrigation-water supply at local and, in some instances, subregional scales.

- Groundwater quality, particularly regarding elevated nitrate concentrations in recently recharged groundwater, is changing over time and, because of the slow rates of water movement in the aquifer, could affect groundwater availability for decades and even millennia.

\section{Conversion of Rangeland to Irrigated Cropland Affects Water Quality}

NAWQA findings indicate that the nitrogen and pesticide applications on irrigated cropland result in substantially more nitrate and pesticides being transported to the water table at irrigated cropland settings than at rangeland settings. In some locations, however, the change in recharge chemistry following conversion of rangeland to cropland results from the mobilization by irrigation water of large natural nitrate and chloride deposits in the unsaturated zone (above the water table). See Chapter 4 for more details.

\section{Implications}

- Reducing the acreage of rangeland that is converted to irrigated cropland in areas that contain large natural subsurface nitrate and chloride deposits (currently not delineated across the entire High Plains aquifer) is likely to be an effective way to reduce the dissolution and transport of natural chemical constituents in recharge water and resulting adverse effects on water quality in the aquifer.

- Implementing efficient agricultural-chemical application and irrigation technologies in areas not currently implemented to reduce deep percolation of irrigation water and chemicals under cropland is likely to be an effective way to reduce the adverse effects on the quality of the recently recharged groundwater.

\section{Chemical Transport to the Water Table Follows Fast and Slow Paths}

NAWQA findings indicate that chemical transport to the water table occurs by fast and slow paths through the unsaturated zone. In most locations studied, estimated chemical transit times from land surface to the water table exceeded the period of agricultural activity and imply that agricultural chemicals should not yet be present at the water table. In fact, agricultural chemicals are commonly detected at the water table beneath irrigated cropland. This apparent discrepancy is explained by localized fast or preferential flow paths that enable water and chemicals to move quickly through the unsaturated zone to the water table.

Fast paths are most likely to be present beneath topographic depressions in the land surface in which surface runoff from irrigation or precipitation collects. Slow paths are most likely to be present in areas of fine-grained sediments or beneath flat terrain where surface water does not collect. Along fast paths, water and chemicals from land surface may reach the water table in months to decades. Along slow paths, water and chemicals from land surface are likely to reach the water table in centuries to millennia. See Chapter 4 for more details.

\section{Implications}

- Reducing the amount of untreated agricultural and urban runoff to topographic depressions or other fast-path zones is likely to reduce the rapid transport of contaminants to the water table and be an effective management strategy toward minimizing groundwater contamination. 


\section{Important Differences Exist Between the Quality of Shallow Groundwater and Deep Groundwater}

NAWQA findings indicate that changes in water quality have occurred over time that may affect the sustainability of the groundwater resource in the High Plains aquifer. Important spatial differences in the concentrations of dissolved solids, nitrate, pesticides, arsenic, and other constituents were observed between the quality of shallow and relatively young groundwater and the quality of deep and relatively old groundwater. Dissolved-solids concentrations in shallow groundwater generally increased from north to south in the High Plains aquifer and were significantly greater in the southern part (median of 800 milligrams per liter $[\mathrm{mg} / \mathrm{L}]$ ) than in the northern and central parts (medians of about 450 to $500 \mathrm{mg} / \mathrm{L}$ ). Nitrate above local background concentrations (4 mg/L as nitrogen [Chapter 4]) in shallow groundwater was detected throughout the High Plains aquifer. Nitrate concentrations in shallow groundwater were greater than the background concentration in 90 percent of samples from the northern, 60 percent of samples from the central, and 55 percent of samples from the southern High Plains. Although widely detected, pesticide concentrations in shallow groundwater were less than USEPA drinking-water standards in all but 2 of 119 samples. Atrazine and its degradate deethylatrazine were the most commonly detected pesticide compounds. Concentrations of arsenic in shallow groundwater were significantly greater in samples from the southern High Plains than in samples from the northern High Plains. About 40 percent of the samples in the southern High Plains exceeded the USEPA arsenic drinking-water standard of $10 \mu \mathrm{g} / \mathrm{L}$, whereas none exceeded the standard in the northern High Plains. See Chapter 4 for additional information about the quality of shallow groundwater that was mostly recharged during the past 50 years.

The quality of deeper groundwater that is used by many private, public-supply, and irrigation wells in the High Plains generally is of suitable quality for most uses, although some spatial differences in water quality are observed across the region. Based on USEPA drinking-water standards, the quality of deeper groundwater decreases from the northern High Plains to the southern High Plains where the water contains greater concentrations of dissolved solids, chloride, nitrate, fluoride, manganese, arsenic, and uranium. These elevated constituent concentrations in deeper groundwater from the southern High Plains are the result of natural processes, such as water/rock interactions, and human activities, such as the mixing of high-quality groundwater with lower-quality water from underlying hydrogeologic formations, induced by pumping of high-capacity wells. See Chapters 5 and 6 for more details.

\section{Implications}

- The quality of groundwater near the water table may not be currently suitable for human consumption in some locations of the aquifer because of elevated concentrations of salts, nitrate, and (or) pesticides. However, the quality of groundwater in deeper parts of the aquifer, with some exceptions, currently is generally suitable for human consumption.

- The quality of groundwater that is influenced by mixing with brackish surface water or water from underying hydrogeologic formations may not be suitable for irrigation or drinking-water supply in some locations of the aquifer because of the elevated concentrations of dissolved solids.

- Groundwater remediation is expensive, slow, and impractical across regional-scale aquifers. Therefore, management practices that prevent groundwater contamination are likely to be a more effective way to maintain the availability and sustainability of groundwater in the High Plains aquifer for the intended uses for human consumption and agricultural practices.

- Collecting long-term monitoring data is likely to be an effective way to detect gradual temporal trends and to provide early warning of water-quality problems (nitrate, for example) for which the aquifer may have limited natural-attenuation capacity.

\section{Mixing of Groundwater by High-Capacity Wells with Long or Multiple Screens Adversely Affects Water Quality}

NAWQA findings indicate that the quality of deeper groundwater from private, public-supply, and irrigation wells, which typically are completed using one long or multiple screens across much of the saturated thickness of the High Plains aquifer, is sometimes affected by mixing with poorer-quality water from the water table. The mixing is caused by leakage through long or multiple well screens and long-term pumping of high-capacity public-supply and irrigation wells. In other instances, pumping of high-capacity wells causes water in the aquifer to be affected by mixing with saline water from underlying bedrock aquifers or with water from streams that is of poorer quality based on USEPA drinking-water standards. See Chapter 5 for more details. 


\section{Implications}

- The following management strategies are likely to help reduce adverse effects on the quality of water in deep zones of the aquifer caused by mixing processes:

- reduce the screen length of public-supply and irrigation wells, and optimize the spatial and temporal distribution of pumping to minimize mixing and water-table drawdown;

- eliminate the practice of screening wells across confining layers in the aquifer; and

- practice screening wells below confining layers in the aquifer where contaminant sources at the land surface are a concern, and practice screening wells above confining layers in the aquifer where contaminant sources in underlying bedrock are a concern.

- Proper construction of wells to limit the movement of low-quality groundwater above and (or) below a well screen will result in maintaining a higher-quality groundwater supply for a variety of uses.

\section{The Aquifer Has Limited Ability to Naturally Attenuate Some Contaminants}

NAWQA findings indicate that the High Plains aquifer is limited in its ability to naturally attenuate some contaminants, such as nitrate. Denitrification, the primary natural process for removing nitrate in groundwater, generally occurs very slowly in the aquifer and would require hundreds to thousands of years to lower nitrate concentrations by just $1 \mathrm{mg} / \mathrm{L}$ as nitrogen $(\mathrm{N})$ in many locations. Additionally, because water residence times in the aquifer are long (several thousand years in some locations), simply flushing nitrate from the aquifer could take many years. These results highlight the importance of managing land use in the High Plains to minimize the amount of nitrate entering the aquifer. See Chapter 5 for more details.

\section{Implications}

- In the indefinite future, the aquifer will continue to be subject to the effects of mobilized agricultural chemicals on groundwater quality from ongoing irrigation, conversion of rangeland to cropland, or climate variability.

- The long transit times of nitrate through the unsaturated zone will undoubtedly delay future improvements in water quality from implementation of best management land-use practices.

\section{The Quality of Most Water Produced by Private, Public-Supply, and Irrigation Wells is Suitable for the Intended Uses}

NAWQA findings indicate that the quality of groundwater from deeper in the High Plains aquifer, where most private, public-supply, and irrigation wells are screened, is generally suitable for drinking and as irrigation water. Comparison of privatewell water quality to USEPA national primary and secondary drinking-water standards indicates that water from the Ogallala Formation in the northern and central High Plains had the best water quality, whereas water from the Ogallala Formation in the southern High Plains had the poorest quality. Most exceedances of primary and secondary drinking-water standards were those for dissolved solids, nitrate, arsenic, fluoride, iron, manganese, and nitrate. The most frequently detected pesticide compounds were atrazine and deethylatrazine, and the most frequently detected volatile organic compound was chloroform. None of the pesticide compounds or volatile organic compounds exceeded a primary drinking-water standard. See Chapter 6 for more details.

\section{Implications}

- If contaminated, the deep zones in the aquifer, in which production wells are screened, are not likely to be remediated quickly because of slow recharge rates, long water residence times in the aquifer, and slow rates of contaminant degradation. 


\section{Background on the Water Resource Beneath the High Plains}

"The enormous Ogallala [High Plains] aquifer is groundwater trapped below 174,000 square miles of fertile but otherwise dry plains farmland. Unlike most of the world's water supplies, Ogallala groundwater is largely nonrenewable because its sources were cut off thousands of years ago. It is essentially "fossil water" that was generated ten thousand to twenty-five thousand years ago from the glacier-laden Rockies....However, more than three billion acre-feet (an acre-foot is a foot of water across one square acre, or 325,851 gallons) had been deposited under the plains.'

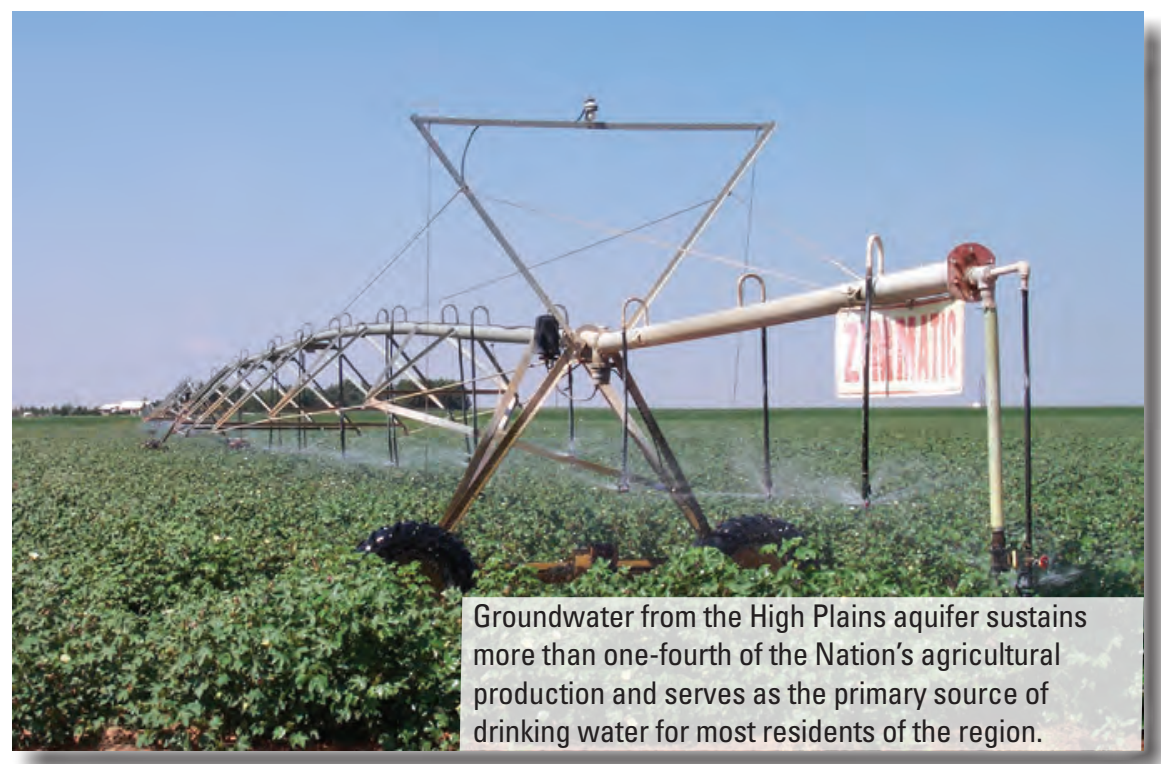

Photograph by Lynne S. Fahlquist, USGS.

This chapter summarizes background information for the High Plains aquifer, thus providing the context for understanding findings about water quality in this hydrologic system. Topics include the environmental setting, population and land use, water use, hydrogeologic setting, water-quality issues, and availability and sustainability of groundwater. 


\section{Environmental Setting}

The High Plains aquifer underlies about 174,000 square miles $\left(\mathrm{mi}^{2}\right)$ in parts of eight Western States (Colorado, Kansas, Nebraska, New Mexico, Oklahoma, South Dakota, Texas, and Wyoming) (fig. 2-1). In 2000, the High Plains aquifer had an estimated 2,980 million acre-feet of drainable water in storage, making it one of the largest aquifers in the world (McGuire, 2007).

Elevations of the High Plains range from about 1,000 feet along the eastern boundary to about 8,000 feet along the north western boundary (fig. 2-1). The topography is characterized by flat to gently rolling terrain.

The High Plains has a middle-latitude dry continental climate (average annual air temperature ranges from 40 to $65^{\circ} \mathrm{F}$ ), characterized by abundant sunshine, moderate precipitation (average annual precipitation ranges from 12 to 33 inches), frequent winds, low humidity, and a high rate of annual evaporation (60 to 109 inches) (Dennehy and others, 2002). The large areal extent of the High Plains results in relatively large northto-south temperature gradients (cooler in the north and warmer in the south) and east-to-west precipitation gradients (more precipitation in the east and less precipitation in the west).
Figure 2-1. The High Plains aquifer underlies 174,000 square miles and eight States. NAVD, North American Vertical Datum of 1988.

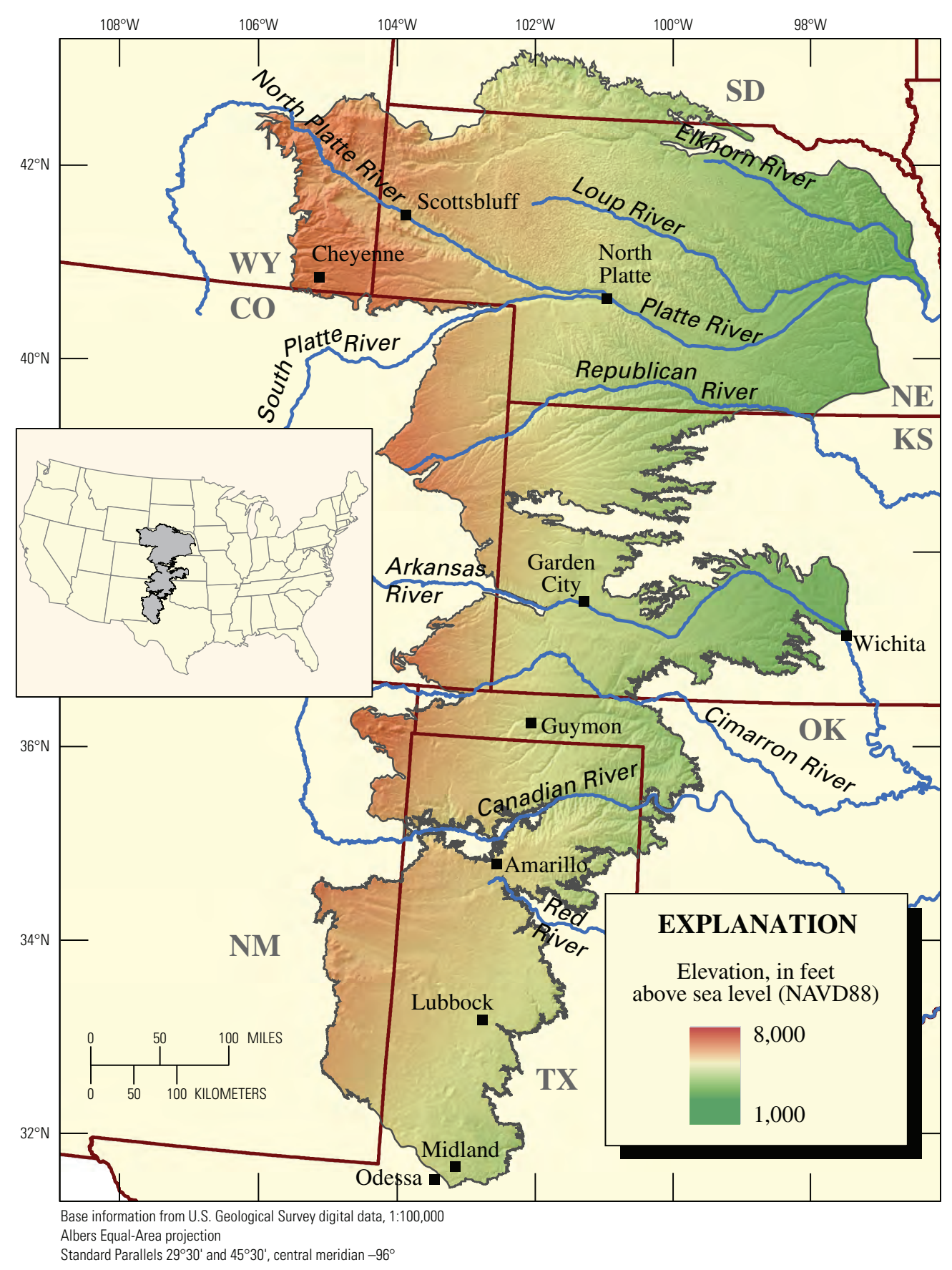




\section{Population and Land Use}

The population of the study area in 2000 was approximately 2.3 million people. The majority ( 77 percent) of this population resides in rural areas and smaller towns and cities, while only 23 percent of the residents live in the four largest cities: Lubbock, Tex. $(199,564)$, Amarillo, Tex. $(173,627)$, Midland, Tex. $(94,996)$, and Cheyenne, Wyo. $(53,011)$. The dominant land use/land cover is rangeland (about 56 percent) and agriculture (about 38 percent, in cultivated crops, small grains, fallow, and pasture/hay); urban land use accounts for only 3 percent (fig. 2-2A). About one-third of the agricultural land is irrigated, mostly concentrated in eastern Nebraska, southwestern Kansas, and the west-central part of the Texas Panhandle (fig. 2-2B).
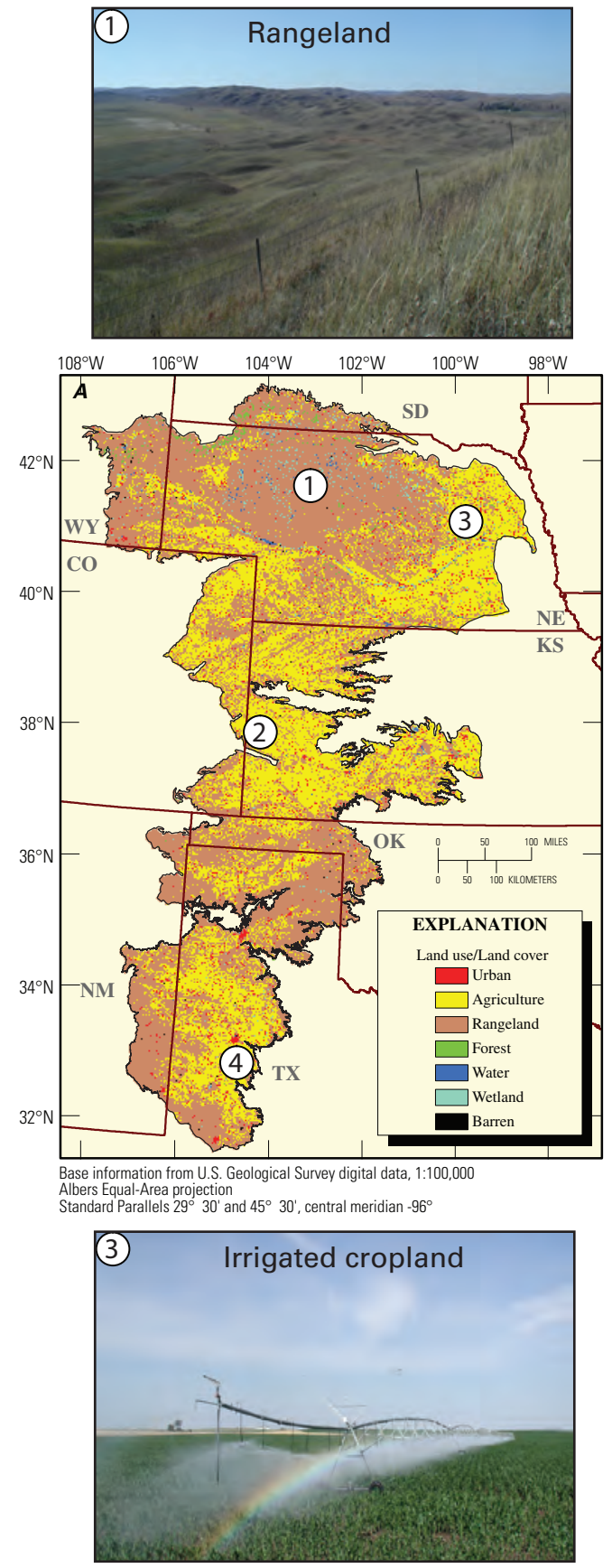
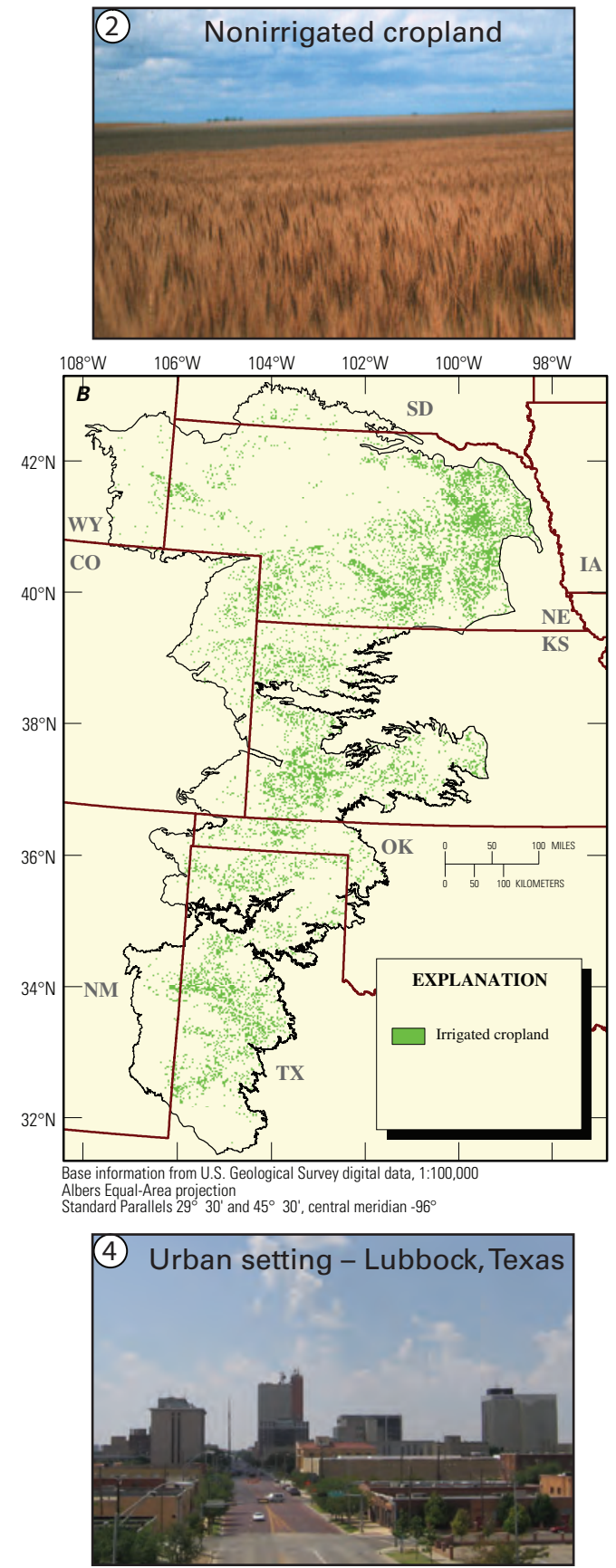

Figure 2-2. (A) The land use/land cover of the High Plains is dominated by natural rangeland and agricultural land (1-3), both of which can affect the quality of groundwater (National Land Cover Database, 2001). Urban areas (4) are relatively small in land area but represent a substantial demand for a high-quality groundwater supply. (B) Although irrigated cropland accounts for about 30 percent of the agricultural land ( $\mathrm{Qi}$ and others, 2002a, b), the high rates of water use and chemical application associated with irrigated cropland can substantially affect water and chemical movement to the water table. Photographs by USGS staff (Breton W. Bruce, Kevin F. Dennehy, and Peter B. McMahon) and Wikipedia (accessed December 30, 2008, at http://en.wikipedia. org/wiki/Lubbock,_TX). 


\section{Water Use}

Use of groundwater from the High Plains aquifer as a source of irrigation water has transformed the study area into one of largest and most productive agricultural regions, earning it the nickname "breadbasket of the world" (Opie, 2000). The High Plains aquifer is the most intensively used aquifer in the United States for irrigation, public supply, and self-supplied industry, producing almost two-times more water than any other U.S. aquifer (Maupin and Barber, 2005). Groundwater withdrawals from the High Plains aquifer in the year 2000 accounted for about 20 percent of total groundwater withdrawn in the United States (fig. 2-3). Most (97 percent) of the water withdrawn from the High Plains aquifer is used for irrigation (fig. 2-3). Although withdrawals for drinking water account for a relatively small percentage of the total groundwater use, they provide drinking water for about 82 percent of the 2.3 million people who live within the study area boundary.

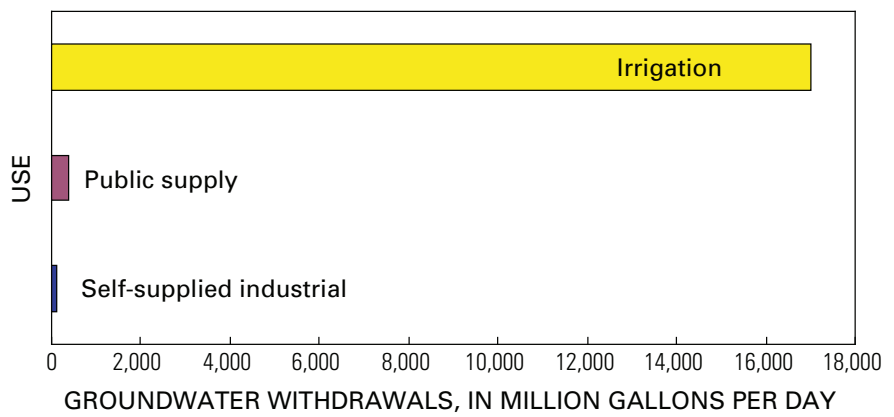

Figure 2-3. Irrigated agriculture is the dominant use of groundwater from the High Plains aquifer (data from the year 2000 and modified from Maupin and Barber, 2005).

\section{Hydrogeologic Setting}

The High Plains aquifer consists of sedimentary deposits that form six hydraulically connected hydrogeologic units. The most extensive of these hydrogeologic units is the Ogallala Formation, which makes up about three-fourths of the total High Plains study area (fig. 2-4).

The depth to water below land surface (unsaturated-zone thickness) ranges from 0 to approximately 500 feet, averages about 100 feet, and is generally greatest in the central and southern High Plains. The saturated thickness of the High Plains aquifer ranges from less than 1 to more than 1,000 feet and averages about 200 feet. The saturated thickness varies geographically and is greatest in the northern High Plains.

Evaporation rates exceed precipitation rates across much of the High Plains, so little water is available to recharge the aquifer. Recharge to the High Plains aquifer occurs by infiltration of irrigation water, areally diffuse infiltration from precipitation, focused infiltration of storm- and irrigationwater runoff through streambeds and other topographic depressions (Gurdak and others, 2008), and upward movement of water from underlying aquifers. Discharge from the High Plains aquifer is primarily to irrigation well pumping, streams and underlying aquifers, groundwater flow across the eastern boundary of the aquifer, and evapotranspiration. Regional groundwater flow is generally from west to east; however, local variability in hydraulic gradients can result in different directions of groundwater flow, particularly near high-capacity pumping wells and major rivers like the Platte, Republican, and Arkansas Rivers (fig. 2-1).

Water levels have declined (fig. 2-5) substantially since predevelopment times (approximately the mid-1950s) because groundwater withdrawals have greatly exceeded recharge across much of the aquifer (McGuire and others, 2003). This is particularly true in the central and southern High Plains. The largest water-level declines range from 50 to more than 150 feet, primarily across parts of Kansas, Oklahoma, New Mexico, and Texas (fig. 2-5). The saturated thickness of the aquifer has decreased by more than 50 percent in some parts of Kansas and Texas. This groundwater depletion has led to increased pumping costs and a reduction of water discharging to streams, among other things. Ecosystems along riparian corridors that rely on groundwater discharge are adversely affected by even small volume changes in the groundwater system (Alley, 2006). 


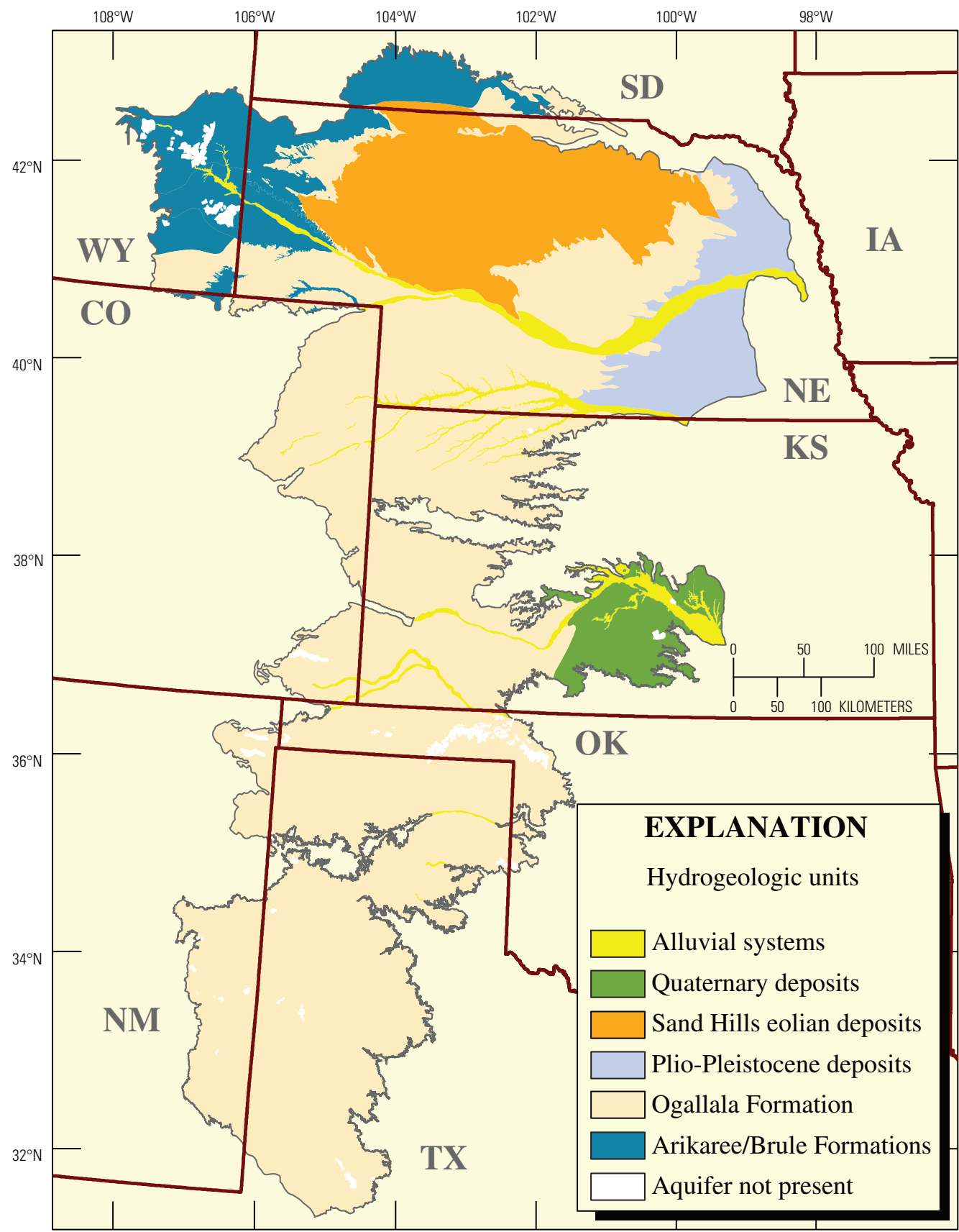

Base information from U.S. Geological Survey digital data, 1:100,000 Albers Equal-Area projection

Standard Parallels $29^{\circ} 30^{\prime}$ and $45^{\circ} 30^{\prime}$, central meridian $-96^{\circ}$

Figure 2-4. The Ogallala Formation is the largest and most important hydrogeologic unit of the High Plains aquifer. 


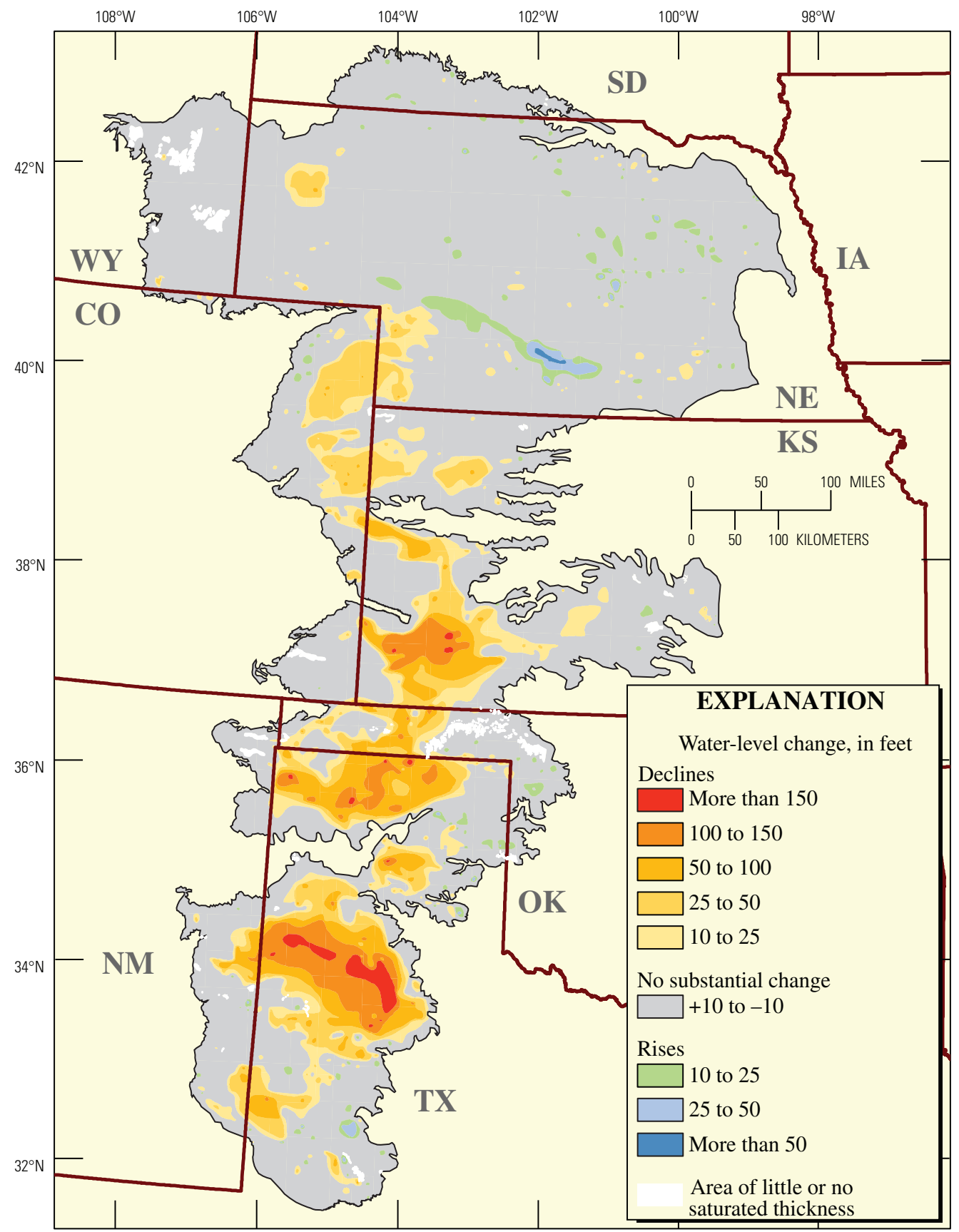

Base information from U.S. Geological Survey digital data, 1:100,000 Albers Equal-Area projection

Standard Parallels $29^{\circ} 30^{\prime}$ and $45^{\circ} 30^{\prime}$, central meridian $-96^{\circ}$

Figure 2-5. The most substantial declines in water levels since predevelopment are in parts of Texas, New Mexico, Oklahoma, and Kansas (modified from McGuire, 2007) and the High Plains water-level monitoring study (http://ne.water.usgs.gov/ogw/hpw/ms/, accessed January 16, 2009). 


\section{NAWQA Approach to Assessing Water Quality in the High Plains Aquifer}

This NAWQA study ( see Box A) provides the first systematic assessment and most comprehensive regional analysis of water quality in the High Plains aquifer. An approach was developed that assessed overall water quality in the aquifer and also enabled an understanding of the linkages between the quality of water recharging the aquifer, the effect of transport through the hydrologic system on water quality, and the quality of the resource used for human consumption and irrigation.

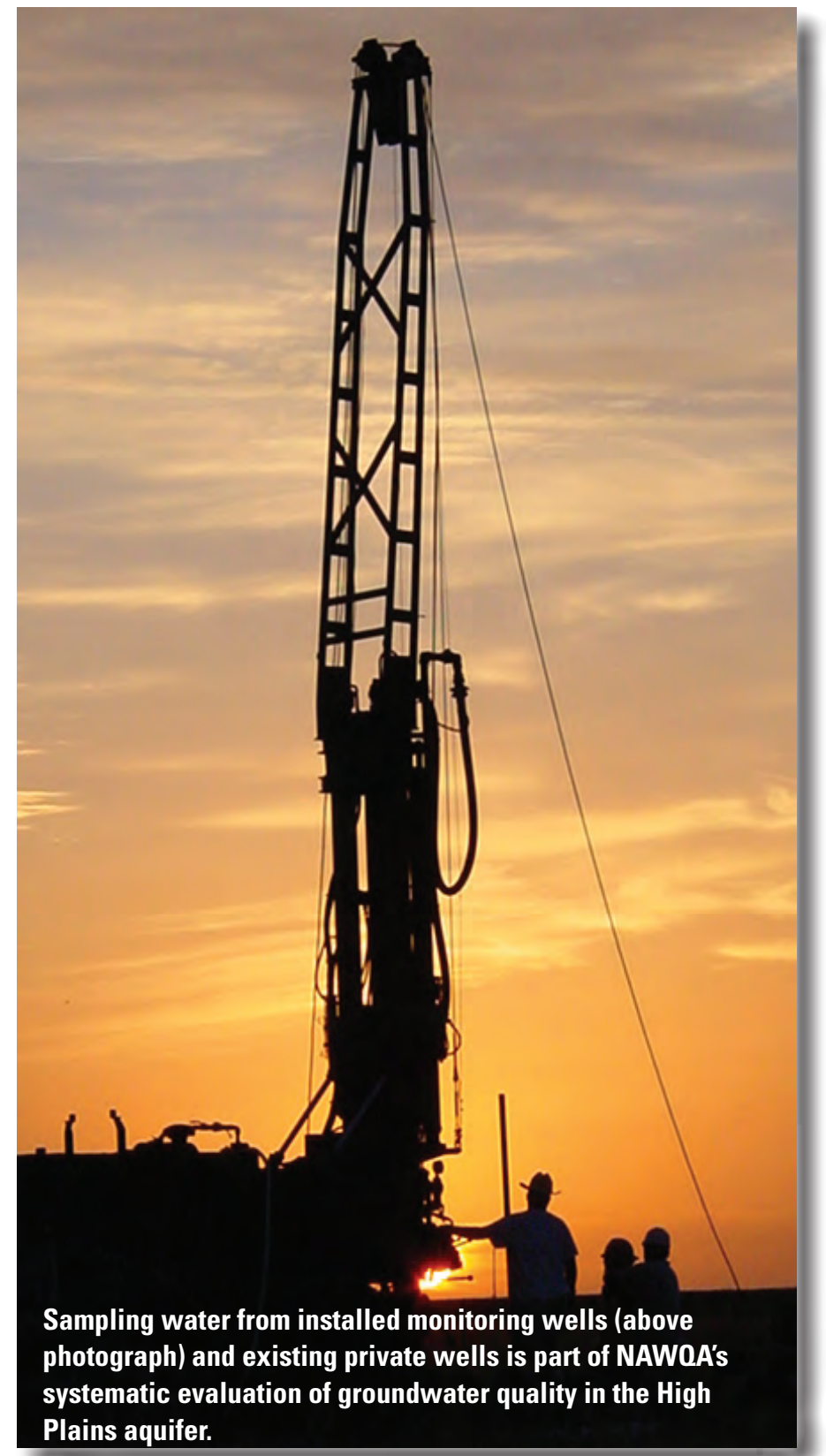

This chapter summarizes the primary features of the NAWOA study design, providing the context for understanding findings about water quality in the High Plains aquifer that are presented in subsequent chapters. 
Water-quality assessments by NAWQA, which is a single program among many local, State, and Federal programs, are not designed to address all of the Nation's waterresource information needs and issues. Listed below are several characteristics and limitations of the NAWQA approach that are important to consider when interpreting the findings presented in this report.

- NAWQA assessments characterize the quality of the available, untreated water resources. The quality of drinking water from water-treatment plants or from household taps is not monitored. By focusing on the quality of streams and groundwater in their present condition (ambient water quality), NAWQA complements many Federal, State, and local drinking-water monitoring programs.

- NAWQA assessments do not focus on specific sites with known water-quality concerns or narrowly defined "issues of the day" but rather on the condition of the total resource, including streams and groundwater in a wide range of hydrologic and land-use settings across the country.

- NAWQA assessments are guided by a nationally consistent study design and uniform methods of sampling and analysis. Findings thereby pertain not only to water quality of a particular stream or aquifer but also contribute to the larger picture of how and why water quality varies regionally and nationally. This consistent, multiscale approach helps to determine if a water-quality issue is isolated or pervasive.

- NAWQA assessments target specific land-use settings that are most extensive or important to water quality in a wide range of hydrologic and environmental settings across the Nation. This targeted approach gives priority to understanding the most critical factors influencing water quality. Extension of results to national analysis, however, requires careful definition of each type of water resource and environmental setting for which conclusions are drawn and the use of statistical models to extrapolate results to resources that have not been measured.

- USGS analytical methods are designed to measure concentrations as low as economically and technically feasible. Studies of contaminant occurrence and behavior benefit from the most information possible at all concentration levels, and such data help to identify emerging issues and to track changes in concentrations over time. By this approach, however, many constituents, such as pesticides and volatile organic compounds, are commonly detected at concentrations far below Federal or State standards and guidelines for protecting water quality. 


\section{Study Components of the High Plains Water-Quality Assessment}

The High Plains water-quality assessment was divided into four study components: unsaturated-zone studies, landuse studies, major aquifer studies, and regional-transect studies (fig. 3-1). The objectives of the unsaturated-zone studies were to measure the amount of chemicals stored in the subsoil above the water table and determine their transit times from land surface to the water table in rangeland and irrigated settings. The objective of the land-use studies was to measure and explain the quality of recently recharged groundwater in irrigated cropland and urban settings by sampling water-table monitoring wells installed as part of the NAWQA Program. The objective of the major aquifer studies was to broadly assess water-quality conditions in the aquifer by sampling networks of randomly selected, areally distributed, existing private wells. The objectives of the regional-transect studies were to characterize vertical gradients in groundwater chemistry and apparent age in the thickest areas of the aquifer and to identify major biogeochemical reactions affecting the quality of water along groundwater flow paths leading from recharge areas to downgradient wells. Details of each study component are explained by McMahon, Dennehy, and others (2007).

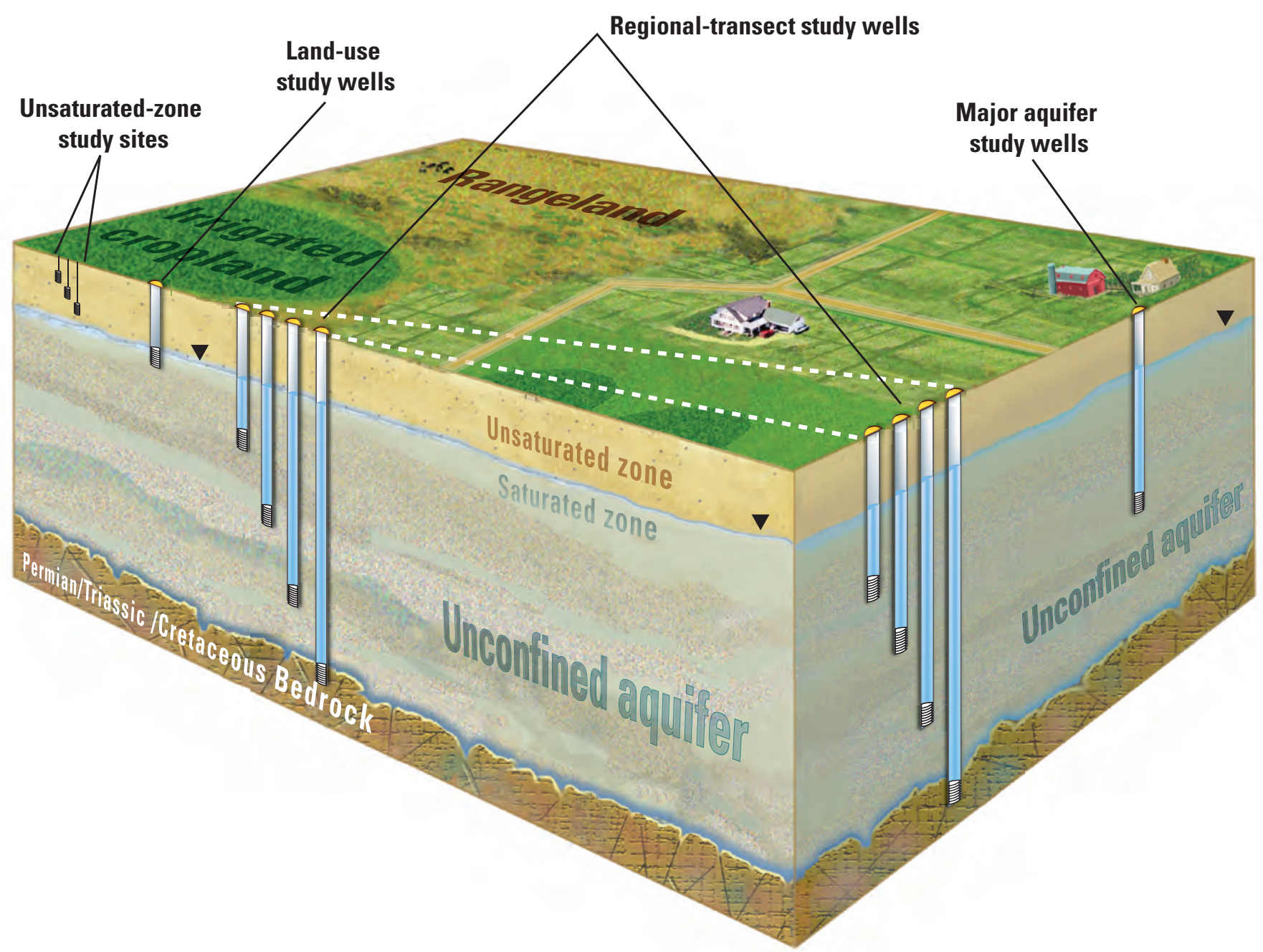

Figure 3-1. The four distinct study components enabled a systematic understanding of the quality of water as it moves from land surface, through the unsaturated zone, to the water table, and finally to deeper depths in the aquifer that are commonly used to supply water for drinking and irrigation. 
The study area was divided into three geographic subregions: northern High Plains (NHP) (96,500 mi²); central High Plains (CHP) (48,500 $\left.\mathrm{mi}^{2}\right)$; and southern High Plains (SHP) (29,000 $\left.\mathrm{mi}^{2}\right)$ (fig. 3-2). These subdivisions are based on considerations of the aquifer boundaries; hydrogeology; regional temperature gradients that affect agricultural practices, land use/land cover, and recharge, and thus water quality; and logistics of conducting field activities across such a large area (fig. 3-3).

An important concept of the High Plains aquifer assessment design was the nesting of the studies described in figure 3-3 and Appendix 2, which resulted in improved understanding of assessment results and supported extrapolation of results to unmonitored areas of the aquifer. An example of the nested design implemented in the central High Plains is shown in figure 3-3. Nested within the major aquifer study was a land-use study targeting irrigated corn agriculture and a regional-transect study characterizing vertical gradients in water chemistry and apparent groundwater age between the water table and base of aquifer. Nested within the land-use study was an unsaturated-zone study of agricultural-chemical storage and transit times in the unsaturated zone.

Monitoring water and chemical movement from the land surface to the water table and from the water table to the base of the aquifer along flow paths leading from recharge to discharge areas resulted in an improved understanding of the timescales at which that movement occurred. This enabled interpretation of local-scale data over a broad range of variability contained within the regional aquifer. Thus, a beneficial aspect of the High Plains aquifer study design is that it bridges the interpretation gap between local-scale studies and the aggregation to regional and national-scale synthesis. Additional information on sampling locations, sampling frequency, and data collected is detailed in Appendix 2. Groundwater-quality data collected by local, State, and other Federal agencies were compiled to help assess the quality of groundwater used for irrigation and public supply, which is described in Chapter 6.

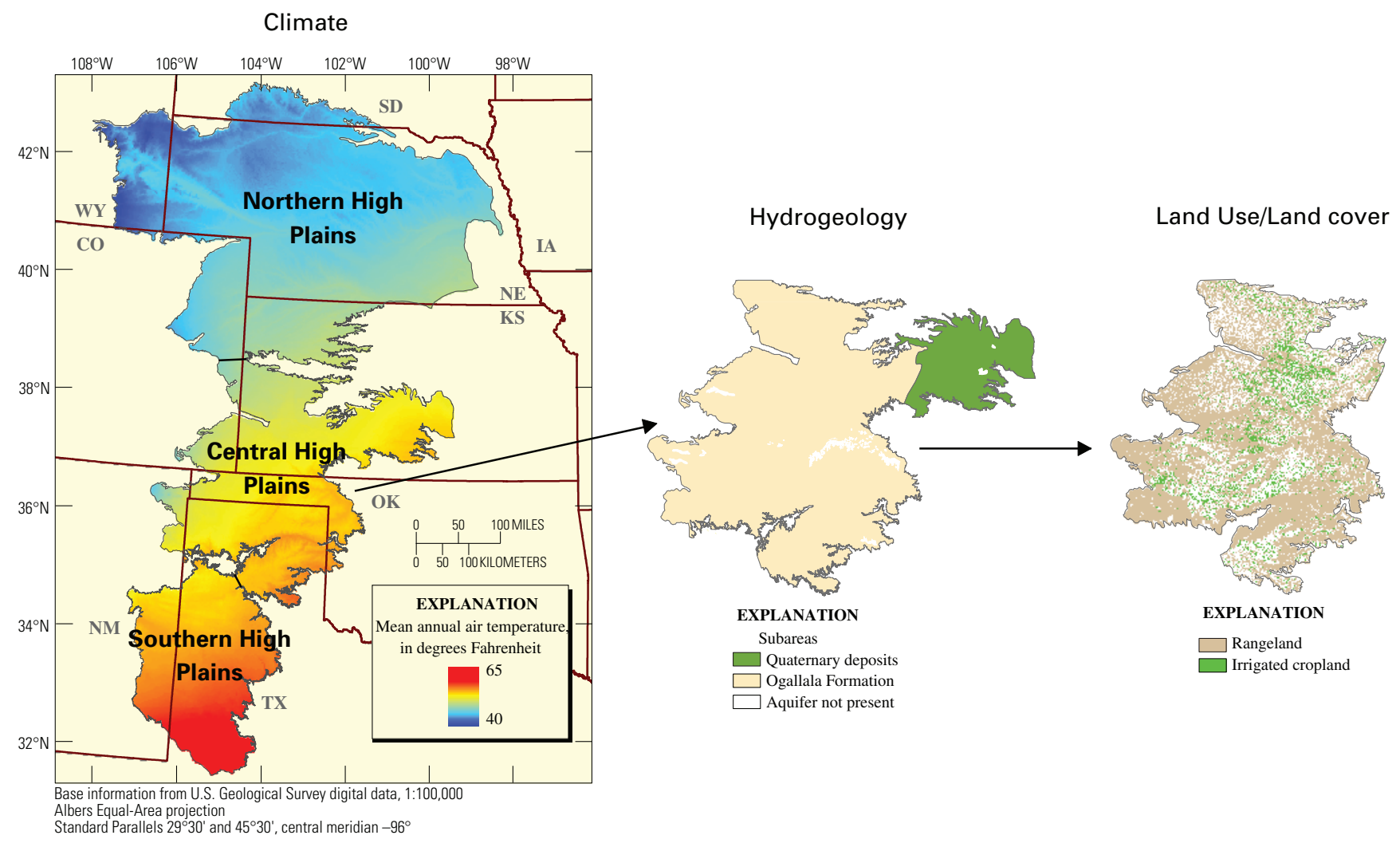

Figure 3-2. A stratification scheme based on climate, hydrogeology, and land use/land cover was used to identify important areas for groundwater quality sampling. 


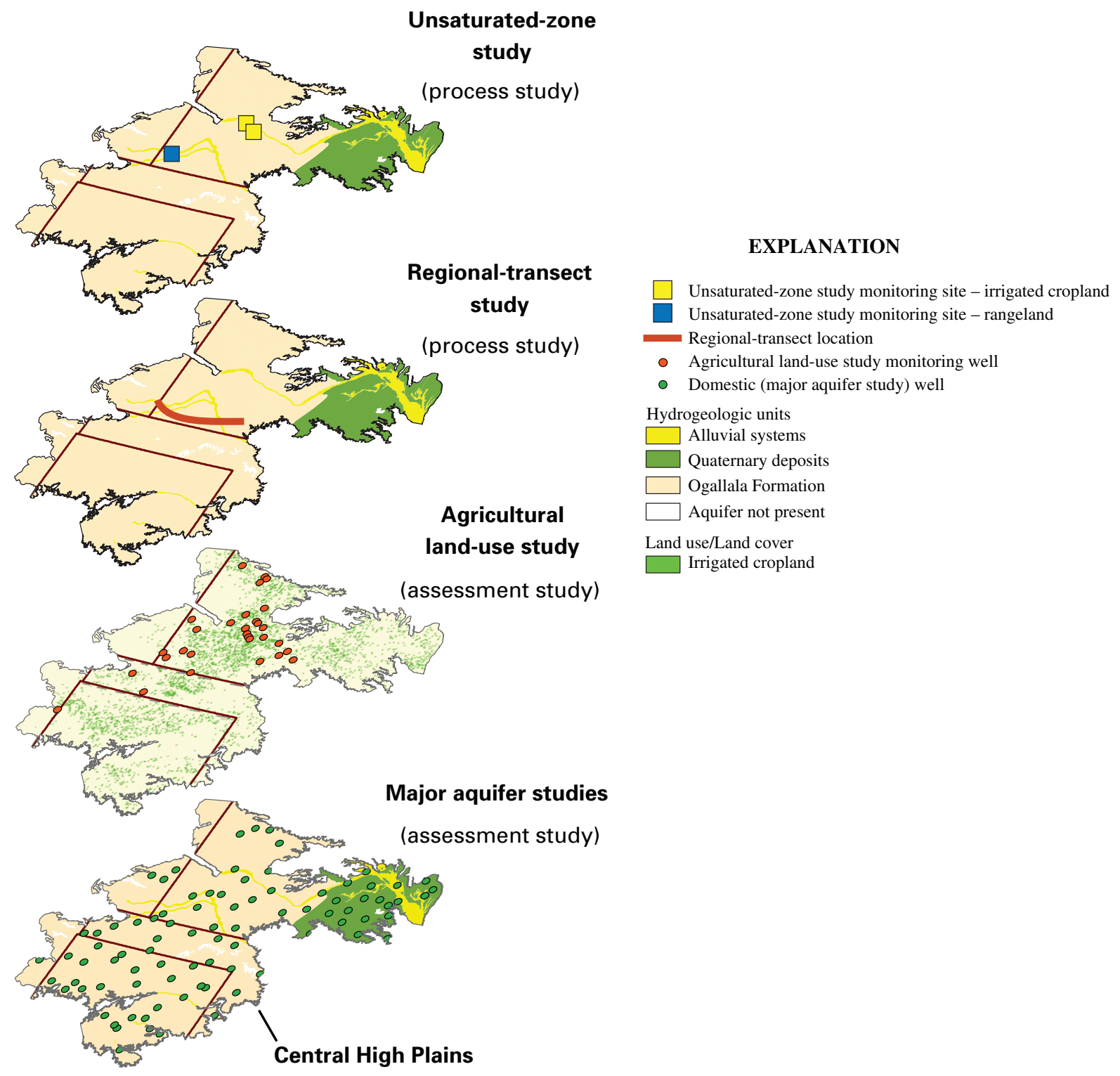

Figure 3-3. The regional assessment used four nested study components (unsaturated-zone studies, land-use studies, major aquifer studies, and regional-transect studies) to better assess groundwater quality conditions and controlling processes at local and regional scales. 
This chapter summarizes the quality of water near the water table. Topics include the occurrence and distribution of selected constituents, the factors affecting water quality, extrapolation to unmonitored locations, and trends in water quality near the water table.

\section{Quality of Water Near the Water Table-
What Was Found, Where, and Why}

A substantial part of the High Plains aquifer assessment focused on the quality of recently recharged groundwater near the water table beneath irrigated cropland used mainly for the production of corn and cotton. For this study, recently recharged groundwater refers to water recharged in the past 50 years. This recently recharged groundwater is an important part of the resource to study because it is likely to contain chemicals from modern agricultural practices that represent a major land use in the High Plains. Moreover, the recently recharged groundwater eventually moves deeper in the aquifer where watersupply wells typically are screened. The unsaturated-zone and land-use studies are used to assess this component of the resource and determine if chemicals introduced at land surface by human activities are reaching the water table.

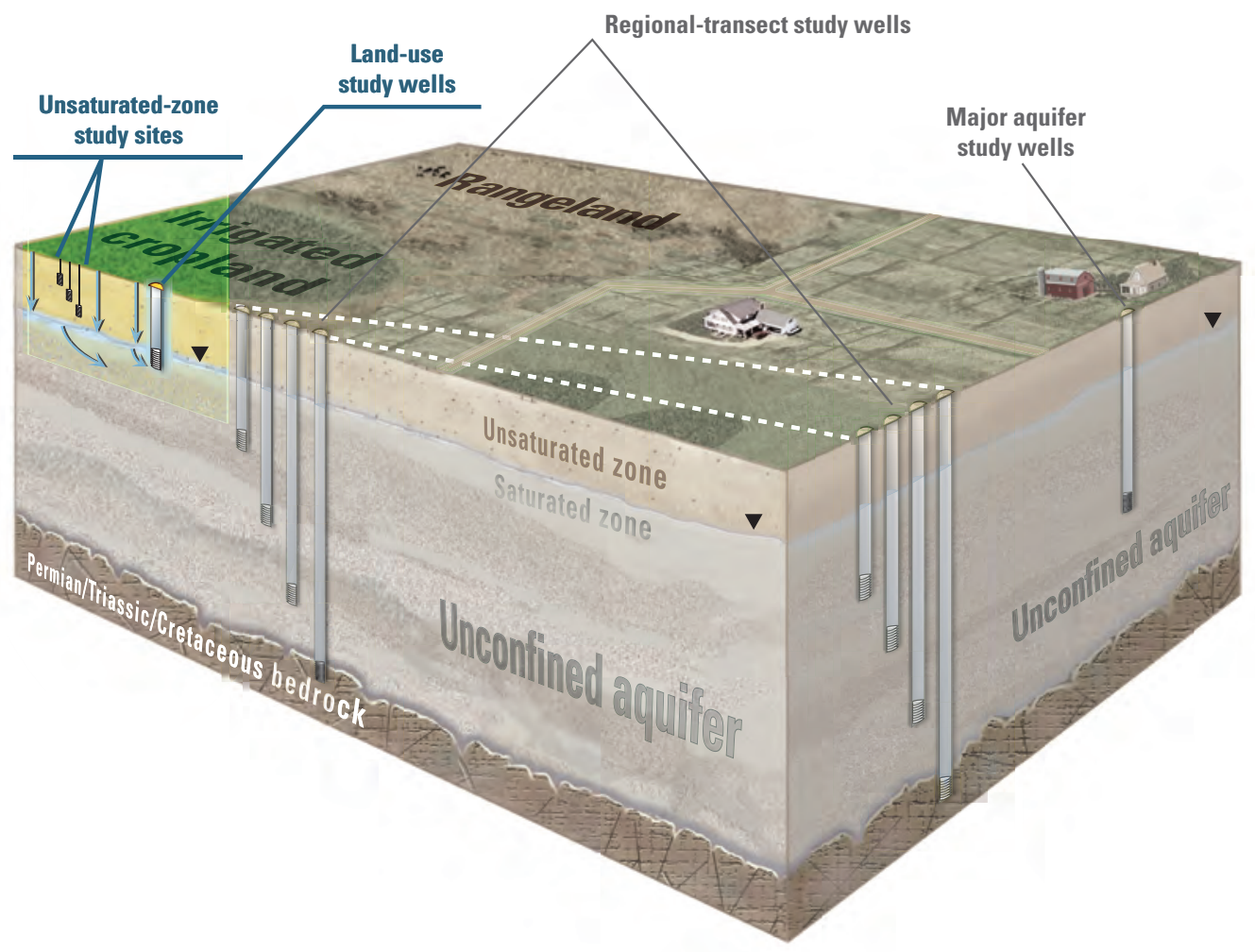




\section{General Findings - Quality of Recently Recharged Groundwater}

In general, NAWQA findings show that dissolved solids, nitrate, pesticides, and arsenic were present in relatively large concentrations in recently recharged groundwater beneath irrigated cropland. The quality of that recently recharged groundwater, however, was not uniform across the High Plains aquifer. Details of the urban land-use study are described by Pope and others (2002).

Dissolved-solids concentrations in recently recharged groundwater beneath the irrigated cropland generally increased from north to south in the High Plains, and were significantly greater in the southern part (median of $800 \mathrm{mg} / \mathrm{L}$ ) than in the northern and central parts (medians of about 450 to $500 \mathrm{mg} / \mathrm{L}$, respectively). Sodium, magnesium, chloride, and sulfate are important contributors to the significant increase in dissolved solids from north to south in the High Plains, all of which can have natural and human sources.

Nitrate was above background concentrations in each of the land-use studies. Nitrate concentrations in shallow groundwater were greater than the background concentration of $4 \mathrm{mg} / \mathrm{L}$ as nitrogen in 90 percent of samples from the northern, 60 percent of samples from the central, and 55 percent of samples from the southern High Plains. Natural nitrate in the High Plains aquifer can be derived from processes such as mineral weathering, decay of organic material, and atmospheric deposition. The background concentration of $4 \mathrm{mg} / \mathrm{L}$ as nitrogen is based on age-dated groundwater samples that were recharged more than 50 years ago. Thus, concentrations greater than $4 \mathrm{mg} / \mathrm{L}$ as nitrogen are likely to include nitrate from other sources, such as fertilizer and manure from agricultural practices.

Pesticides were more commonly detected in shallow groundwater in the northern High Plains than in the central and southern High Plains. Atrazine and its degradate deethylatrazine were the most commonly detected pesticide compounds. Although widely detected, pesticide concentrations generally were low; concentrations of the pesticide compounds were less than established drinking-water standards in all but two of 119 samples. Generally, pesticide compounds were detected most frequently in groundwater that also contained nitrate above background concentrations or that was recharged in the past 50 years.

Concentrations of arsenic in shallow groundwater were significantly greater in the southern High Plains than in the northern High Plains. About 40 percent of the samples from the southern part exceeded the arsenic drinking-water standard of $10 \mu \mathrm{g} / \mathrm{L}$, whereas none from the northern part exceeded the standard.

\section{ZUSGS}

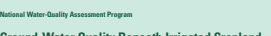

Ground-Water Quality Beneath Irigated Croplan
of the Northern and Southern High Plains Aquiters Nebraska and Texas, 2003-04
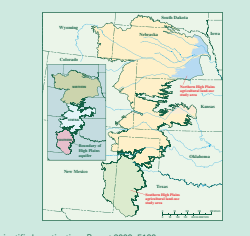

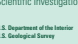

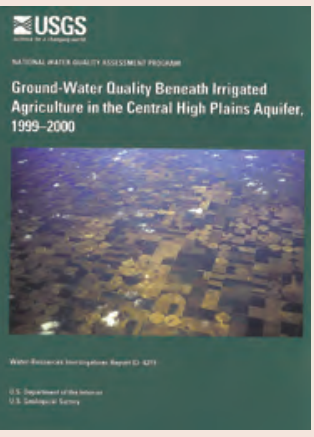

Detailed descriptions of water quality of recently recharged groundwater beneath irrigated cropland are in the following reports:

\section{Ground-water quality beneath irrigated agriculture in the northern and southern High Plains aquifer, Nebraska and Texas, 2003-04}

by J.S. Stanton and L. Fahlquist:

U.S. Geological Survey Scientific Investigations Report 2006-5196 available at http://pubs.usgs.gov/sir/2006/5196

\section{Ground-water quality beneath irrigated agriculture in the central High Plains aquifer, 1999-2000}

by B.W. Bruce, M.F. Becker, L.M. Pope, and J.J. Gurdak:

U.S. Geological Survey Water-Resources Investigations Report 2003-4219 available at http://pubs.usgs.gov/wri/wri034219 


\section{Factors Affecting Quality of Recently Recharged Groundwater}

Several factors may control the observed regional differences in water quality of recently recharged groundwater beneath irrigated cropland, including land-management practices involving chemical use and water use, natural reservoirs of nitrate in the subsoil, storage of chemicals in the unsaturated zone, chemical transit times in the unsaturated zone, and climate.

The north-to-south decrease in nitrate concentrations and frequency of pesticide-compound detections are consistent with patterns of chemical use in those regions. Fertilizer and pesticide application rates are larger in the northern High Plains than in the southern High Plains. The amount of water used for irrigation is smaller in the northern part, but natural recharge is greater and depths to the water table are less than in the central and southern parts, which can result in shorter transit times of chemicals from the land surface to the water table in the northern High Plains.

Processes that promote recharge of agricultural chemicals such as irrigation and certain other farming practices can increase the potential for groundwater contamination by increasing chemical movement, thereby decreasing chemical transit times to the water table. Recharged water is being degraded by infiltration of water from repeated irrigation applications in which concentrations of dissolved solids have increased because of evaporative concentration on land surface and in the near subsurface (McMahon, Dennehy, and others, 2007).

Elevated concentrations of dissolved solids in groundwater beneath irrigated cropland are derived in part from application of agricultural fertilizers at the land surface, which can increase the salt load moving to the water table. Subsoil salt deposits, including perchlorate salts (Rajagopalan and others, 2006), also can occur naturally. NAWQA findings suggest that about 80 percent of chloride in the subsoil beneath one irrigated field may be from natural sources. Natural subsoil chloride deposits in the High Plains probably were derived from long-term evaporative concentration of chloride from atmospheric deposition near the base of the root zone in rangeland settings. This evapoconcentration process is dependent on climate, vegetation, topography, and soil type. Subsoil salt deposits increase from the north to the south in the High Plains along with air temperatures; warmer air temperatures tend to increase evaporation and reduce recharge, both of which can result in the accumulation of atmospheric chloride in the unsaturated zone (McMahon and others, 2006).

Conversion of rangeland to irrigated cropland could result in increasing groundwater chloride concentrations over time in the southern part of the High Plains aquifer as natural subsoil salt deposits are mobilized and transported to the water table by irrigation return flow. Mobilization of natural salt deposits has already occurred in some areas of the High Plains, but slow chemical transit times indicate that many of those salts generally have not reached the water table. Thus, the amount of salts (chemical mass) entering the aquifer could increase in the future as the stored chemicals, which currently reside in the unsaturated zone, are mobilized, transported downward in the unsaturated zone, and reach the water table.

For the most part, less nitrate is stored in the subsoil beneath rangeland than beneath irrigated cropland in the High Plains (fig. 4-1), which is consistent with the much larger nitrogen application rates on cropland compared to rangeland. Large natural nitrate deposits, however, have been detected in the subsoil beneath rangeland in some locations (fig. 4-2). Some nitrate could be mobilized in the unsaturated zone by irrigation return flow if the rangeland is converted to cropland, which could lead to increased nitrate concentrations in the aquifer. Nitrogen isotopic data (see Box $B)$ indicate that nitrate from both fertilizer and natural sources are mobilized under the high recharge conditions that occur beneath irrigated fields (fig. 4-2). 


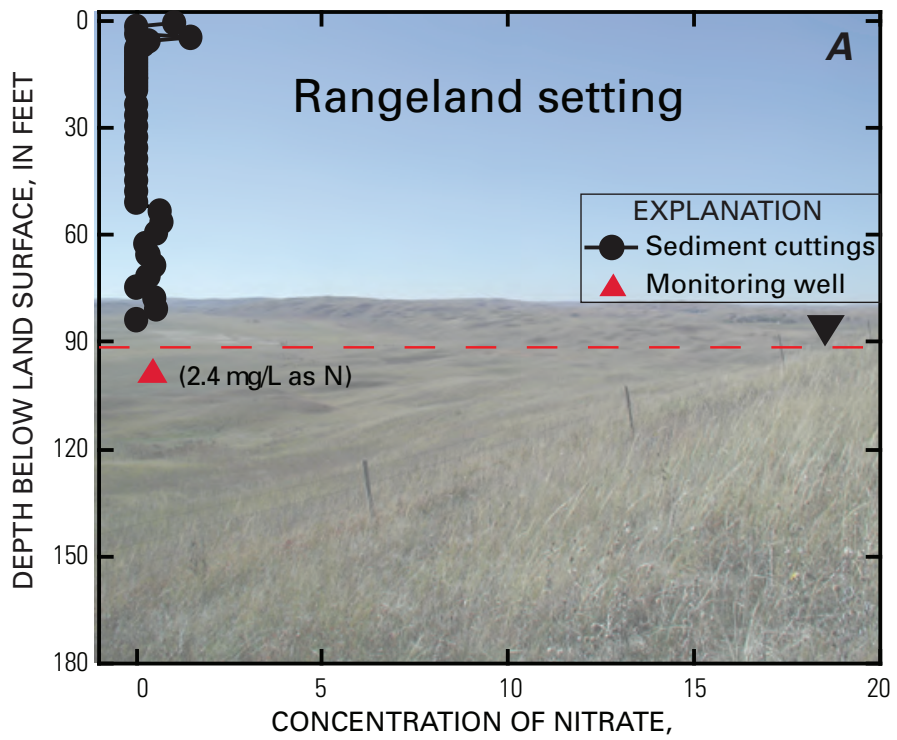

IN MICROGRAMS OF NITROGEN PER GRAM OF SEDIMENT

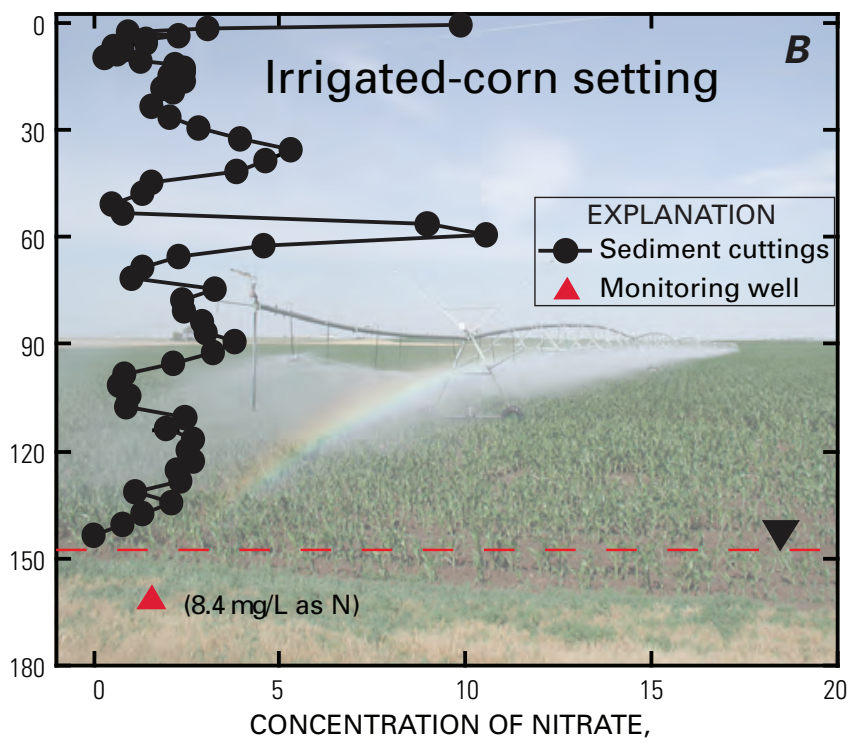

IN MICROGRAMS OF NITROGEN PER GRAM OF SEDIMENT

EXPLANATION

\author{
Water table for 2002 sampling \\ $\Delta(2.4 \mathrm{mg} / \mathrm{L}$ as N) Concentration of nitrate in groundwater, \\ in milligrams per liter as nitrogen
}

Figure 4-1. Generally, less nitrate is stored in the subsoil beneath $(A)$ natural rangeland than beneath $(B)$ irrigated cropland, such as corn fields, in the High Plains. The subsoil nitrate can be derived from natural and agricultural sources. Photographs by Breton W. Bruce and Kevin F. Dennehy (USGS). 


\section{Box How Stable Isotopes Provide Insight into the Sources and Sinks of Nitrate in the Aquifer}

Isotopes of a particular element have the same number of protons in the atomic nucleus but different numbers of neutrons, resulting in different atomic masses. Stable isotopes do not undergo radioactive decay. The relative abundance of isotopes in chemicals of environmental concern, such as the isotopes of nitrogen and oxygen in nitrate, can be precisely measured using mass spectrometry. The element nitrogen has seven protons and either seven or eight neutrons. Thus, nitrogen has two isotopes $\left({ }^{14} \mathrm{~N}\right.$ and $\left.{ }^{15} \mathrm{~N}\right)$, both of which are stable. The element oxygen has 8 protons and either 8, 9, or 10 neutrons. Thus, oxygen has three isotopes $\left({ }^{16} \mathrm{O},{ }^{17} \mathrm{O}\right.$, and $\left.{ }^{18} \mathrm{O}\right)$, all of which are stable. The most abundant isotopes of nitrogen and oxygen in nature are ${ }^{14} \mathrm{~N}$ and ${ }^{16} \mathrm{O}(\mathrm{Coplen}$ and others, 2002).

The isotopic composition of nitrate, and of most other natural materials, is measured relative to standards of known iso-topic composition. Isotope compositions are reported as delta $(\delta)$ values, in units of per mil (\%o). Delta values for the $\mathrm{N}$ and $\mathrm{O}$ isotopes in nitrate are calculated as indicated in the following equations.

$$
\begin{aligned}
\delta^{15} N[\text { nürate }] & =\left(\frac{{ }^{15} N / N_{\text {sample }}}{{ }^{15} N / N_{\text {standard }}}-1\right) \times 1,000 \\
\delta^{18} O[\text { nitrate }] & =\left(\frac{{ }^{18} O /{ }^{16} O_{\text {sample }}}{{ }^{15} O_{\text {standard }}}-1\right) \times 1,000
\end{aligned}
$$

Denitrification is a biological process that reduces nitrate to $\mathrm{N}_{2}$ gas, and it is the most important natural sink for nitrate in groundwater.

Assimilation is a biochemical or abiotic process that uses nitrate or ammonium to form plant proteins and other nitrogencontaining compounds.

Many chemical and physical processes can produce large variations in the relative abundances of $\mathrm{N}$ and $\mathrm{O}$ isotopes in nitrate. This isotopic variability can be useful for distinguishing sources of nitrate and for detecting nitrate-consuming reactions (nitrate sinks). In general terms, the $\mathrm{O}$ isotopic composition of nitrate indicates how the nitrate was formed, whereas the $\mathrm{N}$ isotopic composition provides clues to the source of the $\mathrm{N}$ (figure $B-1$ ). The $\mathrm{N}$ and $\mathrm{O}$ isotopic compositions of nitrate may be altered, or fractionated, by subsequent reactions that consume nitrate, such as assimilation and denitrification (figure $B-1$ ).

Oxygen isotope data indicate that most nitrate in groundwater from the High Plains aquifer is biogenic and not from synthetic (commercial nitrate fertilizer) or atmospheric sources (figure $B-1$ ). Biogenic nitrate is formed by the process of nitrification in which ammonium is oxidized to nitrate. Nitrification in the High Plains commonly occurs in the soil zone above the water table. Sources of ammonium during nitrification include fertilizers, natural soils (including plant material), and manure (shown as blue arrows in figure $B-1$ ). Chemical and isotopic data show that nitrate from fertilizer and manure was most commonly detected in groundwater from agricultural settings such as beneath irrigated cropland. Nitrate from natural soils was detected in groundwater beneath rangeland and cropland, but concentrations generally were small compared to those for nitrate from fertilizer and manure sources.

Evidence for the occurrence of denitrification in the High Plains aquifer is recorded in the $\mathrm{N}$ and $\mathrm{O}$ isotopic composition of nitrate in groundwater that has moved through denitrification zones (McMahon and Böhlke, 2006). Under denitrifying conditions, the delta $\mathrm{N}$ and $\mathrm{O}$ values in nitrate systematically increase as the process consumes nitrate (shown as black arrows in figure $B-1$ ). Thus, $\mathrm{N}$ and $\mathrm{O}$ isotopes help to define the spatial distribution of denitrification in the aquifer. Understanding the spatial distribution of denitrifying zones in the aquifer is important because those areas could be less vulnerable to long-term nitrate contamination compared to zones in which nitrate is not actively consumed. In general, denitrification is not widespread in the aquifer, and rates at which it occurs are slow compared to rates measured in many other aquifers.

\footnotetext{
${ }^{1}$ U.S. Geological Survey, Reston, Virginia.

${ }^{2}$ U.S. Geological Survey, Lakewood, Colorado.
} 


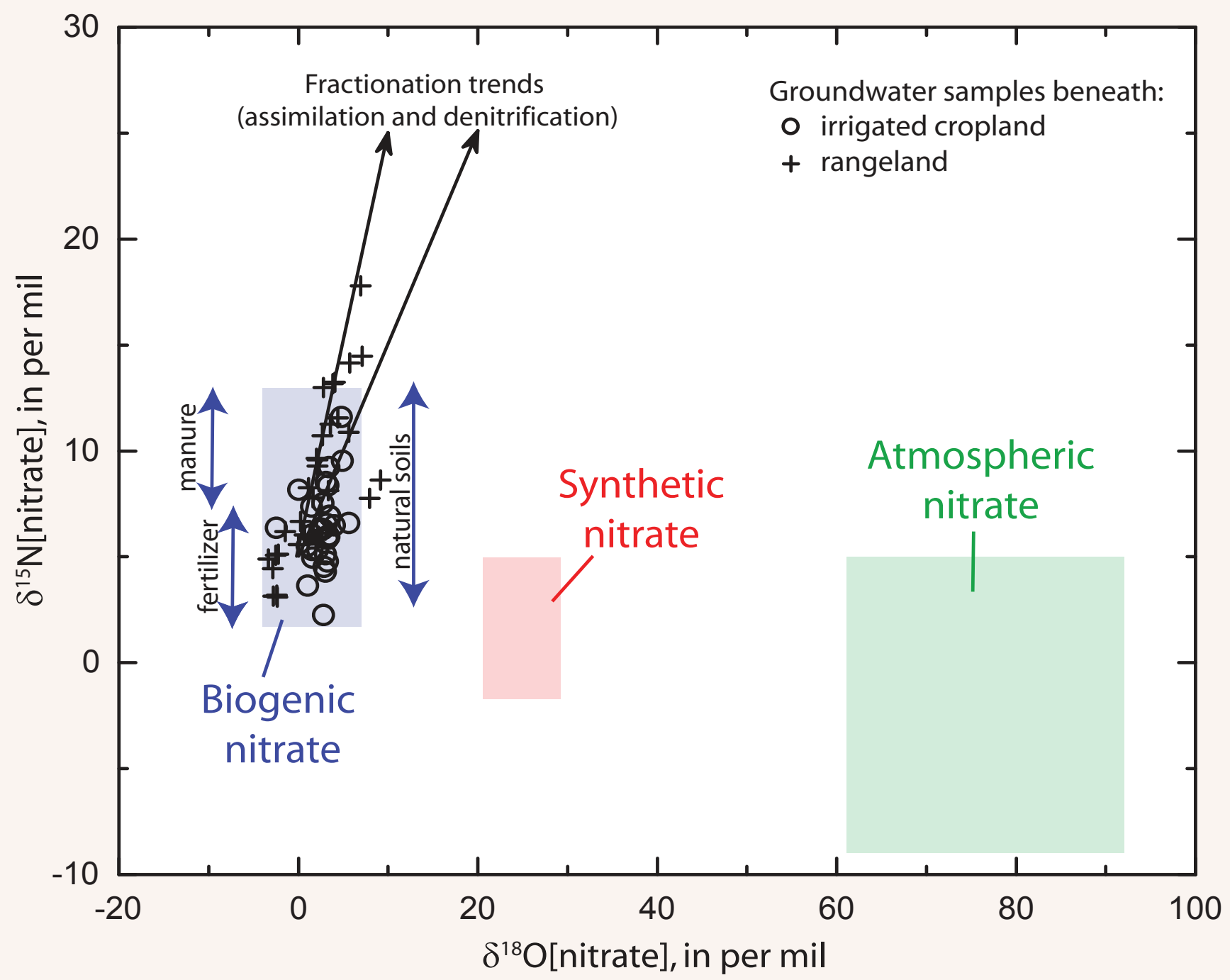

Figure B-1. Nitrogen and oxygen isotopic composition indicates that most nitrate is biogenic in groundwater beneath rangeland and irrigated cropland of the High Plains. 


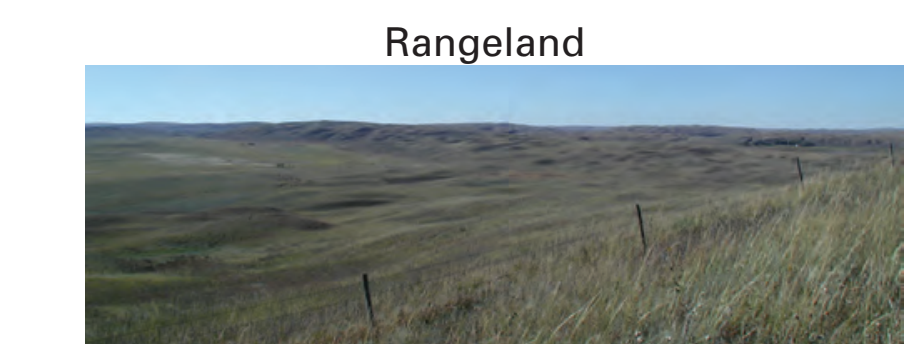

Natural soils

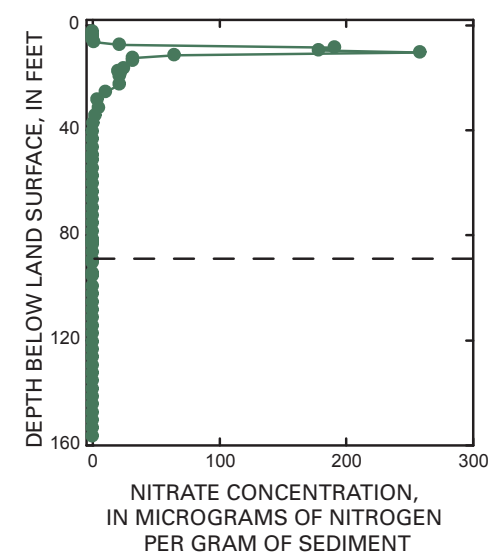

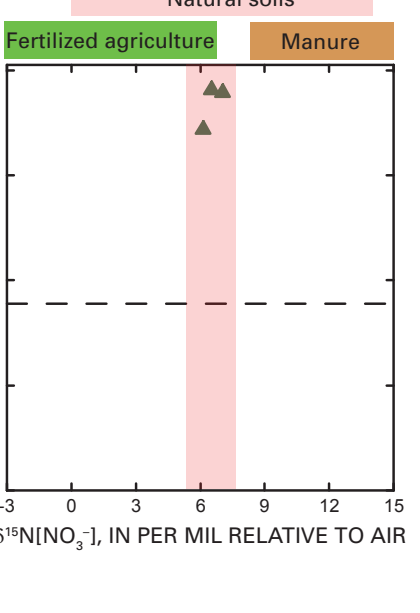

Irrigated corn

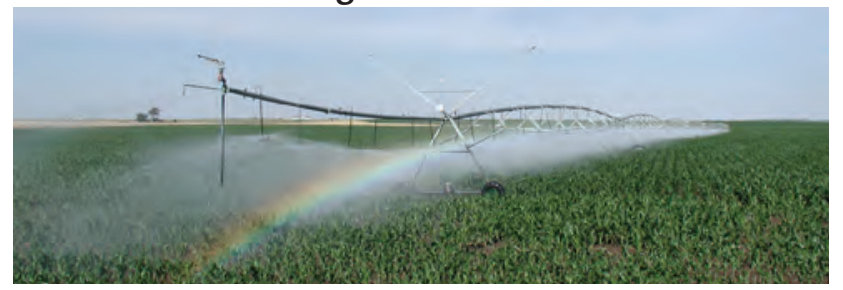

Natural soils

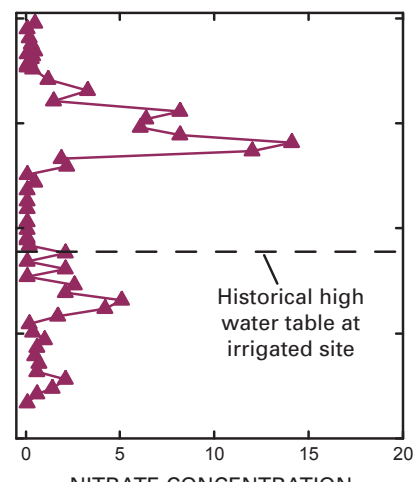

NITRATE CONCENTRATION, IN MICROGRAMS OF NITROGEN

PER GRAM OF SEDIMENT

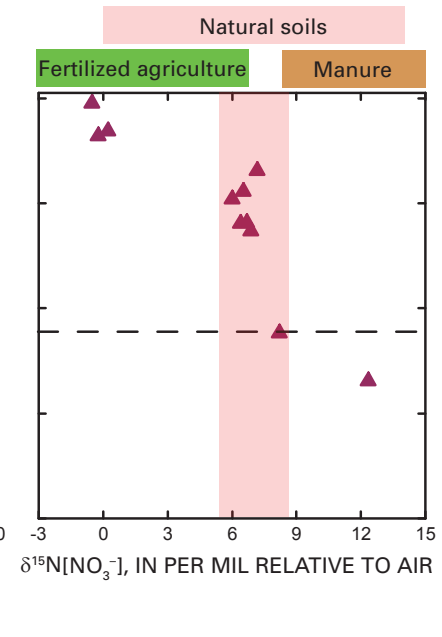

Figure 4-2. Chemical and isotopic data indicate that natural nitrate deposits exist in relatively large concentrations in the unsaturated zone beneath rangeland in some parts of the High Plains (McMahon and others, 2006). When that rangeland is converted to irrigated cropland, some of the nitrate can be mobilized by irrigation return flow, thereby increasing the amount of nitrate moving to the water table. In many locations, these large nitrate concentrations in unsaturated-zone pore water have not yet reached the water table (McMahon and others, 2006). Photographs by Breton W. Bruce and Kevin F. Dennehy (USGS). 
Estimated transit times of water and chemicals through the unsaturated zone beneath irrigated cropland at the unsaturated-zone study sites are highly variable, ranging from 49 to 373 years (McMahon and others, 2006). A major finding is that although the estimated chemical transit times are only approximations, the times exceeded the irrigation period at all of the study sites (28 to 46 years), implying that agricultural chemicals should not have reached the water table, when in fact they have (McMahon and others, 2006). The discordant finding of long chemical transit times beneath irrigated cropland and the presence of agricultural chemicals at the water table cannot be explained as a single flow process in the unsaturated zone and indicates that both fast and slow paths for water and chemical movement are present in the unsaturated zone (fig. 4-3) (McMahon and others, 2006; Gurdak, Hanson, and others, 2007).
Fast paths (with transit times of months to decades) through the unsaturated zone are most likely to occur beneath topographic depressions in the land surface in which surface runoff from irrigation or precipitation collects (such as seasonal ponds or in playas in the southern High Plains) because of the increased hydraulic head by the ponded water (fig. 4-3) (McMahon and others, 2006). Fast paths also could occur through wellbore leakage and through cracks, burrows, fissures, and other soil structural features. Climate variability that occurs on interannual to multidecadal timescales also has been shown to be an important control on transit times beneath fast paths (Gurdak, Hanson, and others, 2007). Slow paths (with transit times of decades to centuries) may occur in finegrained sediments or beneath flat terrain, and possibly in other environments. Evapotranspiration can restrict water movement in both fast and slow path settings (fig. 4-3) (McMahon and others, 2006).

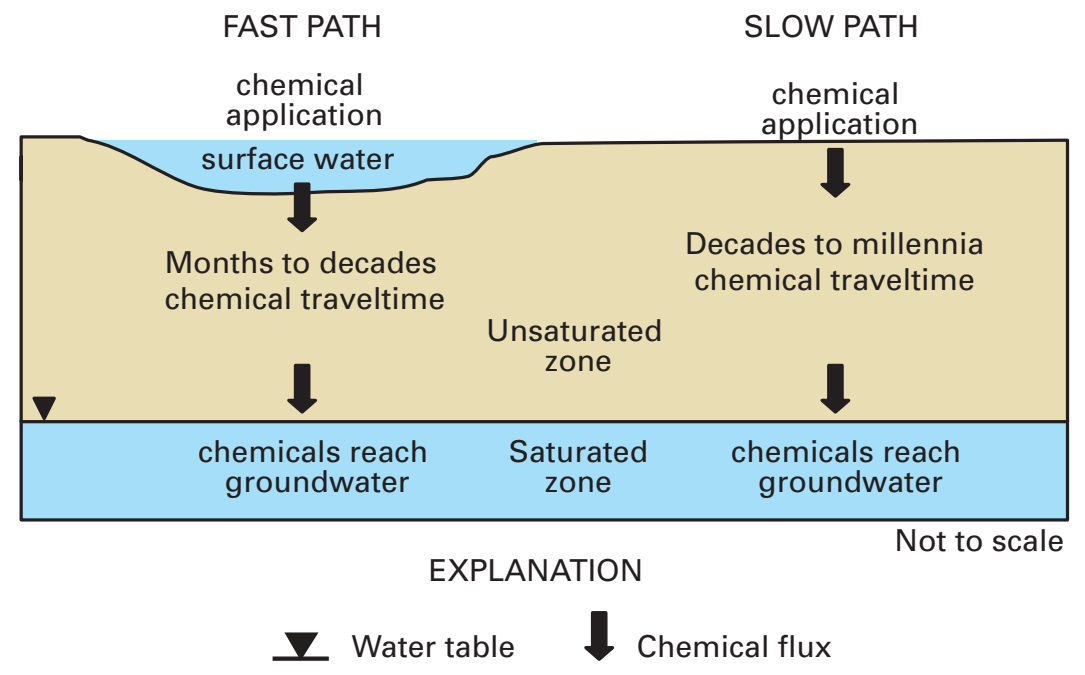

Figure 4-3. Water and chemical movement from land surface to the water table may be slow (decades to millennia) or fast (months to decades) depending on the natural hydrogeology conditions in the unsaturated zone, land-management practices, and climate variability (McMahon and others, 2006; Gurdak, Hanson, and others, 2007; Gurdak and others, 2008). Therefore, it is important to understand the rate of water and chemical movement and the time scales in which best-management practices may affect groundwater quality for determining the implications on the sustainability of a high-quality groundwater supply in the High Plains aquifer. 
Areas of the High Plains containing fast paths for chemical transport to the water table are thought to be a small part of the total High Plains area. For example, previous studies estimated that greater than 50 percent of the recharge to the southern High Plains occurred through playa basin floors that occupied only about 6 percent of the total land area (Claborn and others, 1985; Wood and others, 1997). NAWQA findings indicate that seasonal ponding in irrigated fields (fig. 4-4) can contribute to water and chemical transit times ranging from 7 to 50 years (fig. 4-4). These findings have practical implications for waterresource managers interested in best-management practices designed to reduce nonpoint-source groundwater contamination. For example, limiting the occurrence of seasonal surface ponds caused by leaking chemigation irrigation plumbing is a manageable solution toward reducing elevated concentrations of nitrate and pesticides that reach the groundwater.
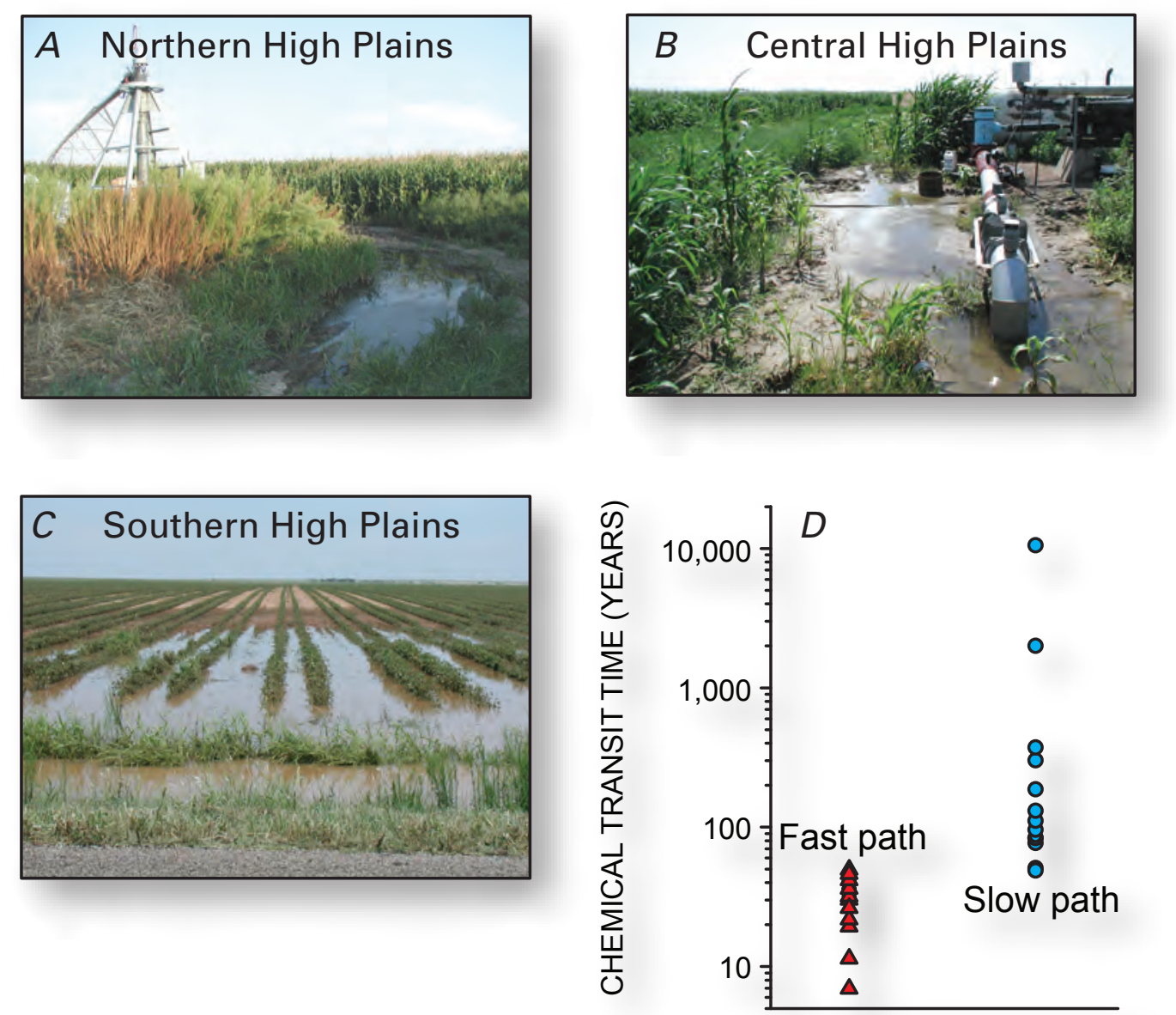

Figure 4-4. $(A-C)$ Seasonal ponding near irrigation wells and in irrigated-agricultural fields creates conditions which can lead to fast paths for water and chemical movement. (D) Simulations indicate that chemical transit times to the water table beneath areas having seasonally ponded conditions (fast paths) are orders of magnitude faster than from field estimates from areas having diffuse recharge settings (slow paths) (Gurdak and others, 2008; and McMahon and others, 2006). Photographs by Jason J. Gurdak and Peter B. McMahon (USGS). 


\section{Extrapolation of Findings to Unmonitored Areas}

Understanding the connection between chemical use at the land surface and the quality of recently recharged groundwater is important but costly to measure across the entire High Plains aquifer. NAWQA sampling provides a basis for extrapolating results to unmonitored areas of the aquifer. Using the monitoring data, a probability map of elevated nitrate concentrations at the water table (fig. 4-5) was developed to evaluate the chemistry of recharge in unmonitored areas of the High Plains aquifer. Output from these types of predictive models can be used to identify potentially vulnerable areas for enhanced monitoring and protection.

\section{"USGS research regarding the vulnerability of the High Plains aquifer to contamination from nitrate is immensely important to protect this valuable resource and has greatly improved our understand- ing of the movement and fate of nitrate and helped us better target our limited monitoring and outreach resources to areas where it is most needed."}

-Troy Bauder, Extension Specialist Water Quality Department of Soil and Crop Sciences Colorado State University

Measured nitrate concentrations in groundwater were used in a model to predict the probability of occurrence of nitrate concentrations greater than background $(4 \mathrm{mg} / \mathrm{L})$ in recently recharged groundwater in unmonitored areas of the aquifer (fig. 4-5). The analysis showed that the features of the aquifer affecting vulnerability to nitrate concentrations greater than background include nonirrigated agriculture, irrigated agriculture, organic matter in the soil, depth to the water table, and average percentage of clay in the unsaturated zone (Gurdak, 2008; Gurdak, McCray, and others, 2007).

Simulation findings suggest that more than half (53 percent) of the aquifer area has less than a 40-percent predicted probability of containing recently recharged groundwater with nitrate concentrations greater than $4 \mathrm{mg} / \mathrm{L}$ as $\mathrm{N}$. The areas of low vulnerability typically are areas that have a relatively small percentage of land in agriculture and relatively thick unsaturated zones that help to protect the aquifer. Approximately 21 percent of the study area has relatively high (greater than 60 percent) predicted probability of containing recently recharged groundwater with nitrate concentrations greater than $4 \mathrm{mg} / \mathrm{L}$ as $\mathrm{N}$. These areas tend to have greater percentages of agricultural land and shallower depths to water table than low-vulnerability areas. The most vulnerable areas (greater than 80-percent predicted probabilities) are scattered across the eastern and southern areas of the northern High Plains and the southernmost areas of the aquifer (Gurdak, McCray, and others, 2007). The vulnerability map (fig. 4-5) is intended for regional, subregional, or county-scale use and might not adequately represent local conditions. Additionally, the vulnerability map (fig. 4-5) was created using data collected from 1990 to 2004 and therefore might not be appropriate for forecasting future conditions in the aquifer (Gurdak and Qi, 2006).

\section{FUSES}

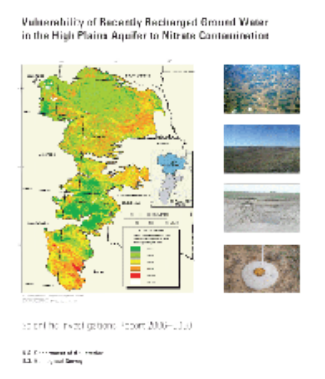

Detailed descriptions of the vulnerability of groundwater in the High Plains aquifer are in the following report:

\section{Vulnerability of recently recharged ground water in the High Plains aquifer to nitrate} contamination

by J.J. Gurdak and S.L. Qi:

U.S. Geological Survey Scientific Investigations Report 2006-5050 available at http://pubs.usgs.gov/sir/2006/5050 


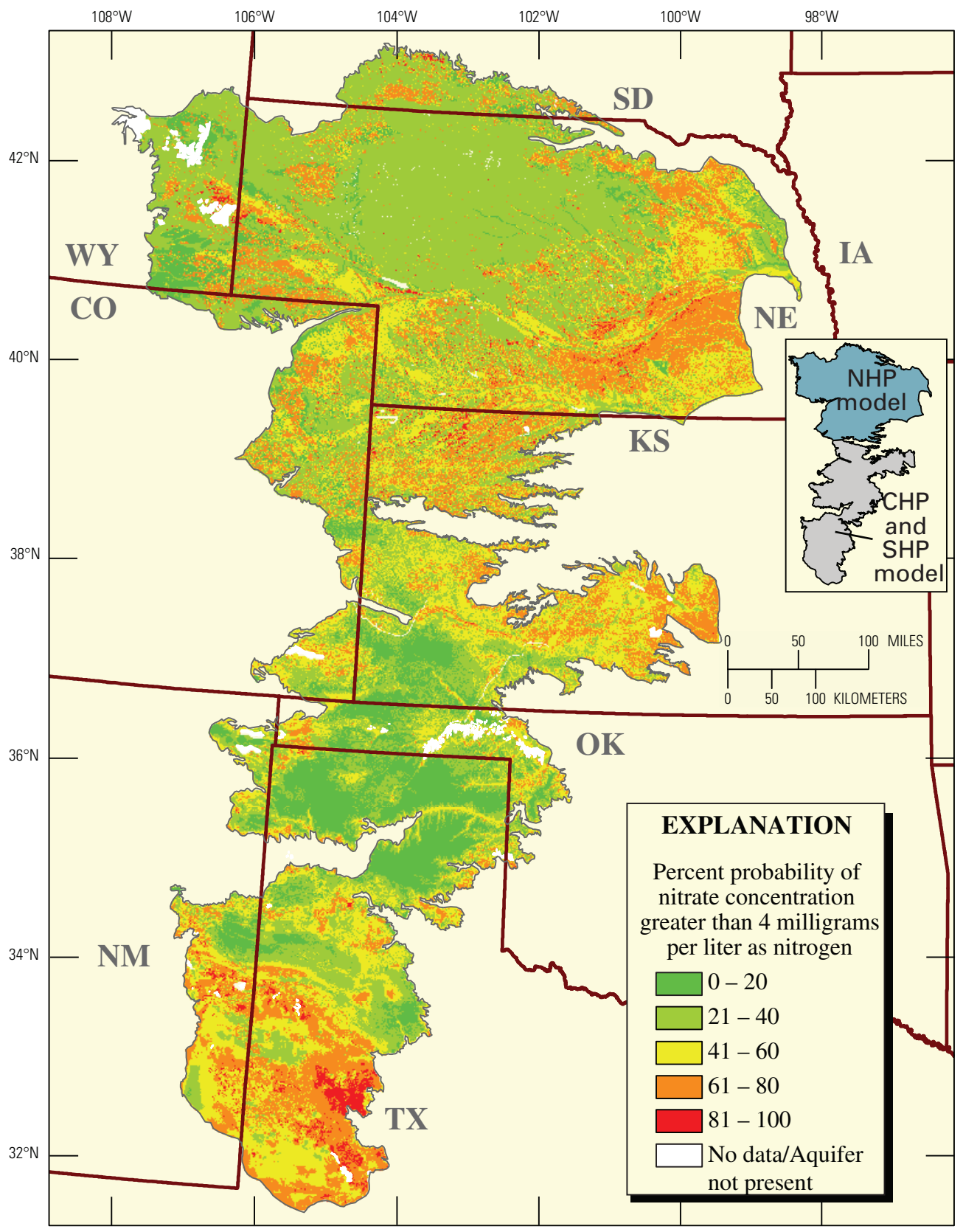

Base information from U.S. Geological Survey digital data, 1:100,000 Albers Equal-Area projection

Standard Parallels $29^{\circ} 30^{\prime}$ and $45^{\circ} 30^{\prime}$, central meridian $-96^{\circ}$

Figure 4-5. The probability of nitrate concentrations greater than 4 milligrams per liter as nitrogen in recently recharged groundwater in the High Plains aquifer is predicted to be much less in the north-central parts of the northern High Plains and the central High Plains than in other areas (Gurdak, 2008; Gurdak and Qi, 2006; Qi and Gurdak, 2006). NHP, northern High Plains; CHP, central High Plains; SHP, southern High Plains. 


\section{Trends in the Quality of Groundwater Recharge}

Long-term trends in concentrations of nitrate in recharge were reconstructed using age-dated groundwater samples. The results showed that during the past approximately 12,000 years, nitrate concentrations in recharge water ranged from 0.8 to $4.2 \mathrm{mg} / \mathrm{L}$ as $\mathrm{N}$, with a median concentration of $2.2 \mathrm{mg} / \mathrm{L}$ as $\mathrm{N}$ (fig. 4-6). However, during the past 50 to 60 years, nitrate concentrations in recharge water have substantially increased compared to concentrations in older recharge water (fig. 4-6). An analysis of existing data collected from 1930 to 1999 confirms the relatively recent increase in nitrate concentrations. The recent increase in recharge nitrate concentrations appears to be related to the increased use of agricultural fertilizer during the past 50 to 60 years (fig. 4-6), although contributions of nitrate from other human sources such as waste from animals and humans, and from natural sources in the subsoil that were mobilized by irrigation returnflow, also may be important.

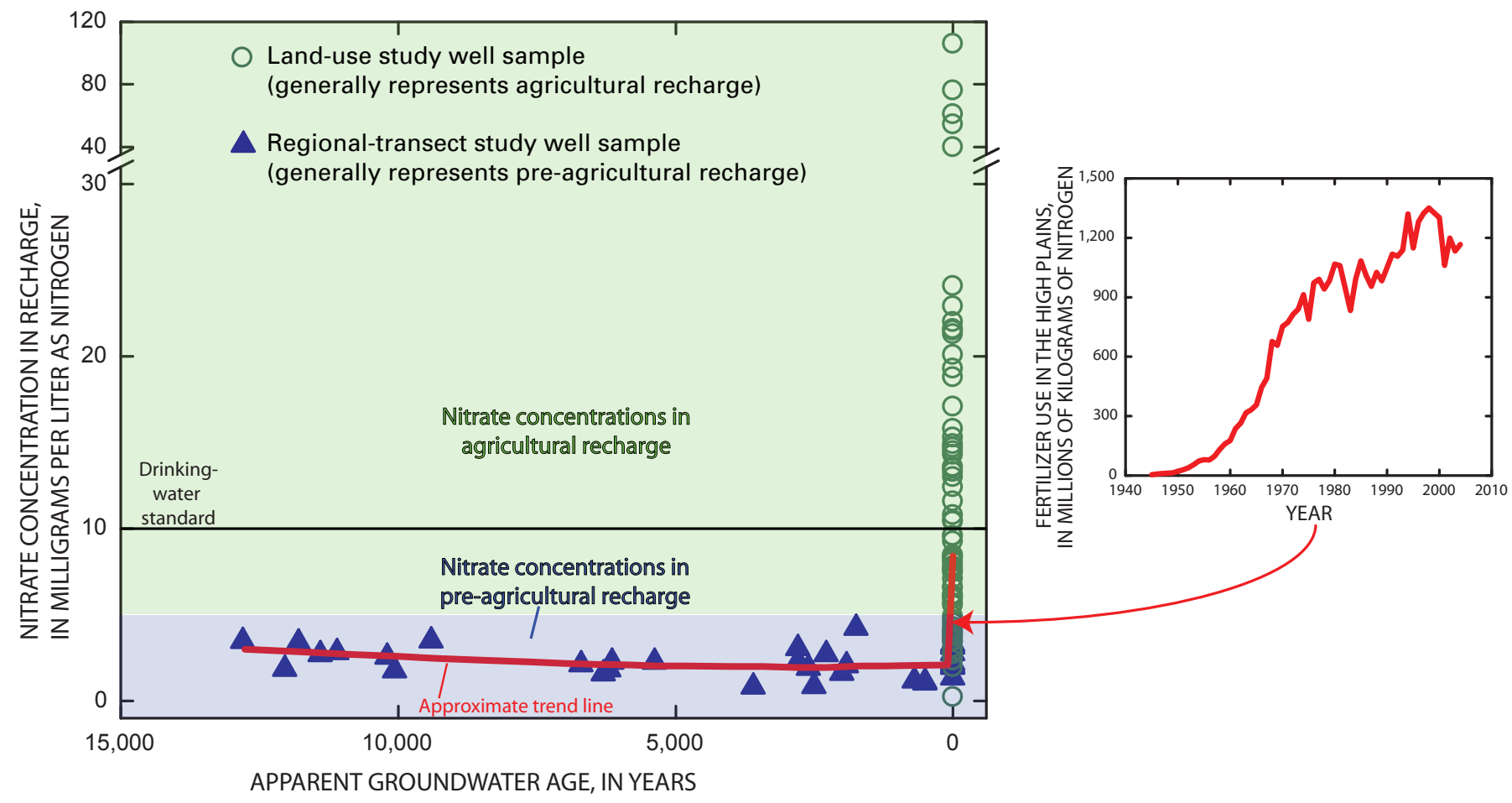

Figure 4-6. The nitrate concentrations in pre-agricultural recharge water during the past $\sim 12,000$ years was relatively stable at approximately 2.2 milligrams per liter as nitrogen. A substantial increase in nitrate concentrations in recharge water since the 1940s and 1950s is the result of agricultural application of nitrogen and mobilization of natural sources of nitrogen in the subsoil by irrigation return flow (McMahon, Böhlke, and Christenson, 2004; McMahon and Böhlke, 2006). 
This chapter summarizes the natural processes and human activities that affect recently recharged groundwater as it moves deeper in the system toward wells used for private, publicsupply, and irrigation uses.

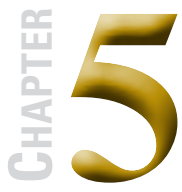

Natural Processes and Human Activities Affecting the Quality of the Water as it Moves From the Water Table to the Resource Used for Drinking and Irrigation

Private, public-supply, and irrigation wells in the High Plains aquifer generally are not screened near the water table but are screened deeper in the aquifer and collect water that has moved deeper within the aquifer. The chemistry of the "used" resource therefore depends on more than the quality of recently recharged groundwater, as described in Chapter 4. Understanding processes that affect the chemistry of water as it moves along flow paths from recharge areas to points deeper in the aquifer is critical to the understanding of water quality in private, public-supply, and irrigation wells. Such processes include water/rock interactions, mixing, and reduction-oxidation (redox) reactions. The regionaltransect study wells are used to assess this component of the resource.

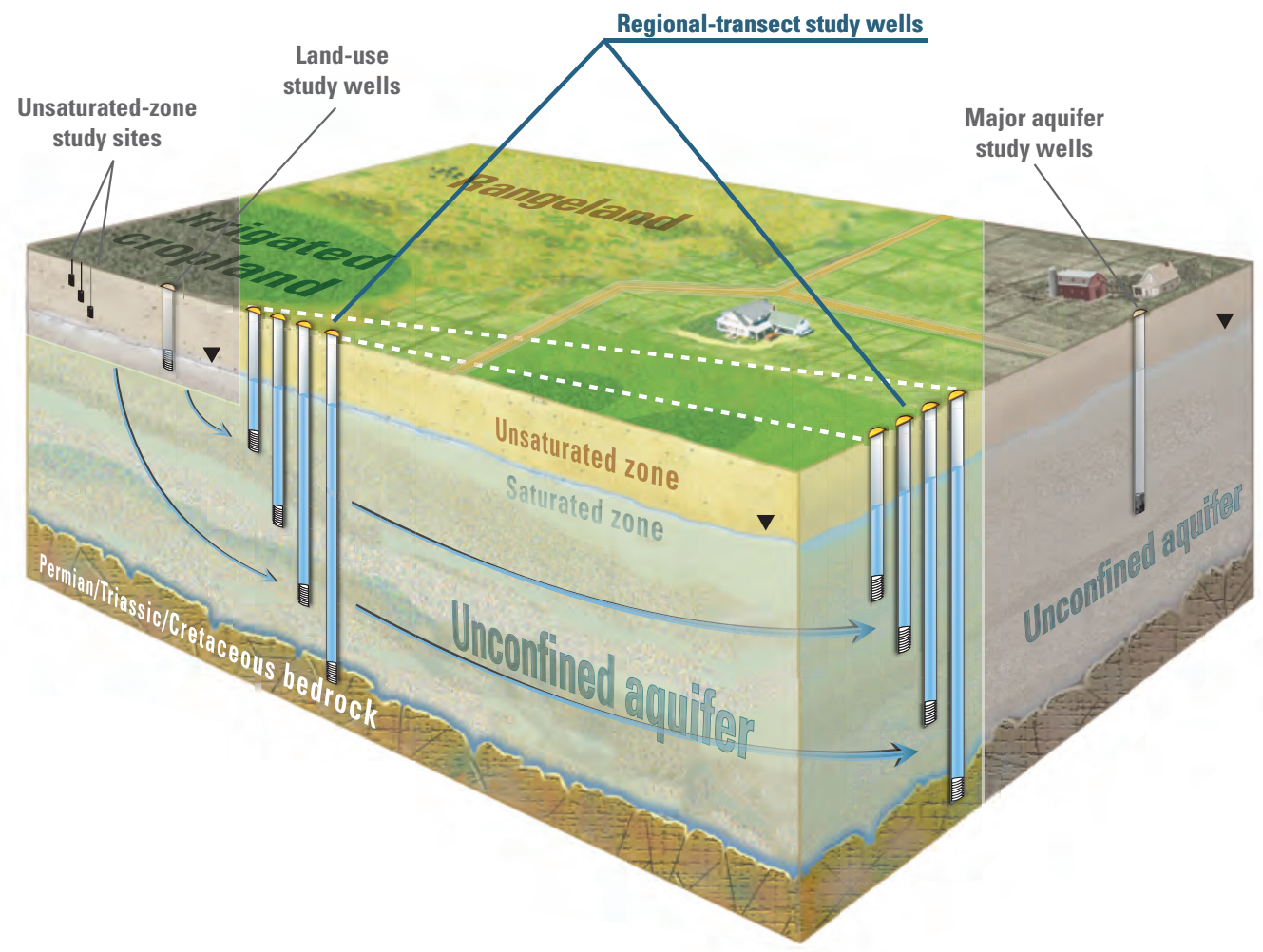




\section{General Findings - Natural Processes and Human Activity}

The relation between the chemistry of the recently recharged groundwater (Chapter 4) and the quality of the resource used for water supplies (Chapter 6) is controlled by multiple natural processes and human activities, including temporal variability in recharge chemistry, groundwater residence time, mixing of water from different sources, and biogeochemical reactions occurring along groundwater flow paths to the private, public-supply, and irrigation wells.

\section{Vertical Gradients in Groundwater Age and Chemistry}

Vertical movement of water in the High Plains aquifer affects the distribution of apparent groundwater ages and chemistry with depth below the water table. Groundwater moves downward in recharge areas and upward in discharge areas, but vertical flow directions can be altered by pumping wells (see Box C) (McMahon and others, 2003; McMahon, Böhlke, and Lehman, 2004).

NAWQA findings indicate that apparent groundwater ages in recharge areas systematically increase with depth below the water table in areas with relatively small amounts of pumping for irrigation or water supply (fig. 5-1A). In areas with relatively large amounts of pumping for irrigation or water supply, apparent-age gradients are less evident or nonexistent at depth, most likely resulting from vertical mixing of water in the aquifer by pumping wells or vertical leakage in wells having long or multiple well screens. Vertical mixing at the more heavily irrigated and developed regional-transect sites affected at least 50 to 65 percent of the saturated thickness of the aquifer (fig. $5-1 B$ ).

One important consequence of mixing shallow and deep groundwater is that widespread contamination of the deep groundwater production zones within the aquifer could occur. Once contaminated, deep zones in the aquifer are not likely to remediate quickly because of slow recharge rates, long water residence times in the aquifer, and slow rates of contaminant degradation (for example, slow denitrification).
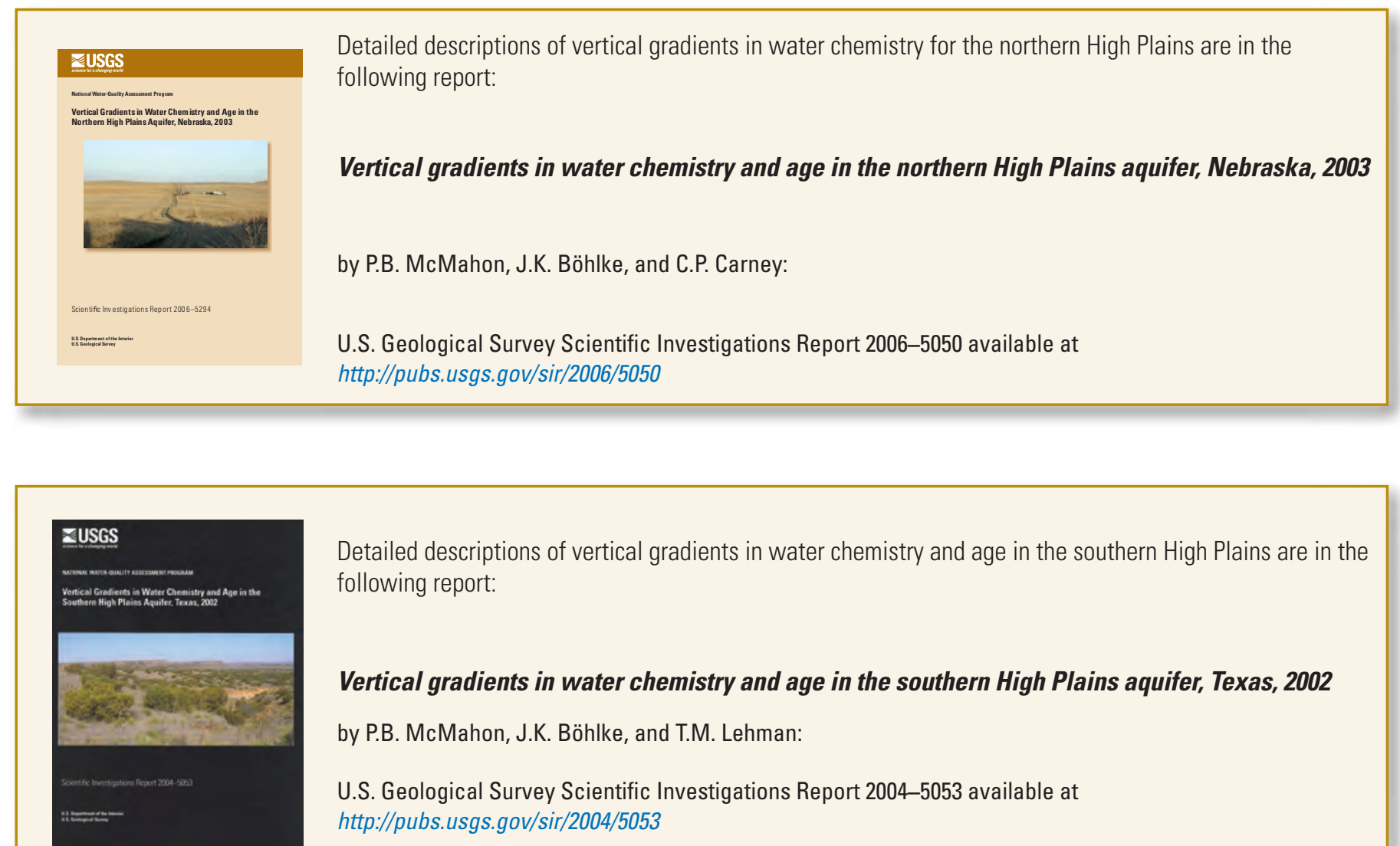

Detailed descriptions of vertical gradients in water chemistry and age in the southern High Plains are in the following report:

Vertical gradients in water chemistry and age in the southern High Plains aquifer, Texas, 2002 by P.B. McMahon, J.K. Böhlke, and T.M. Lehman:

U.S. Geological Survey Scientific Investigations Report 2004-5053 available at http://pubs.usgs.gov/sir/2004/5053 


\section{Box Understanding Vertical Directions of Water Movement in the Aquifer}

\section{using Groundwater-Level Measurement}

Peter B. McMahon' and Jason J. Gurdak¹

Groundwater levels are determined by measuring the depth to water in a well relative to a measuring point of known elevation. Water levels from different wells must be referenced to a common datum, such as sea level, to make them comparable. Thus, water levels usually are reported as elevations above sea level and are referred to as hydraulic heads. Hydraulic heads measured in closely spaced wells screened at different depths in the same aquifer can be used to determine vertical directions of water movement because water moves from areas of high head (or elevation) to areas of low head.

The difference in hydraulic head between two depths in the aquifer, normalized to the vertical distance between the well screens, is referred to as vertical hydraulic gradient. Positive hydraulic gradients indicate the potential for downward water movement and negative gradients indicate the potential for upward water movement. The potential for vertical water movement is directly proportional to the magnitude of the hydraulic gradient.

$$
\text { Vertical hydraulic gradient }=\frac{(\text { hydraulic head })_{\text {shallow well }}-(\text { hydraulic head })_{\text {deep well }}}{\text { vertical distance between well screens }}
$$

\section{Why is it important to measure groundwater levels and understand vertical hydraulic gradients in the High Plains aquifer?}

In general terms, contaminants enter the aquifer at the water table as recharge from the land surface or at the bottom of the aquifer as recharge from underlying geologic formations. Contaminated water at the top or bottom of the aquifer may then move toward the middle of the aquifer, depending on the vertical hydraulic gradient in the aquifer. A downward gradient near the water table would allow contaminants from the land surface to move deeper into the aquifer. An upward gradient near the bottom of the aquifer would permit contaminants from deeper formations to move upward into the aquifer.

Pumping effects on hydraulic gradient are particularly important with respect to contaminant movement in the aquifer. Seasonal development of large downward gradients over many years could be an important mechanism for drawing recently recharged water deeper into the aquifer more quickly than would happen under undisturbed flow conditions. Similarly, a large decrease in water level near the base of the aquifer could induce or enhance upward movement of mineralized water from underlying geologic units. 


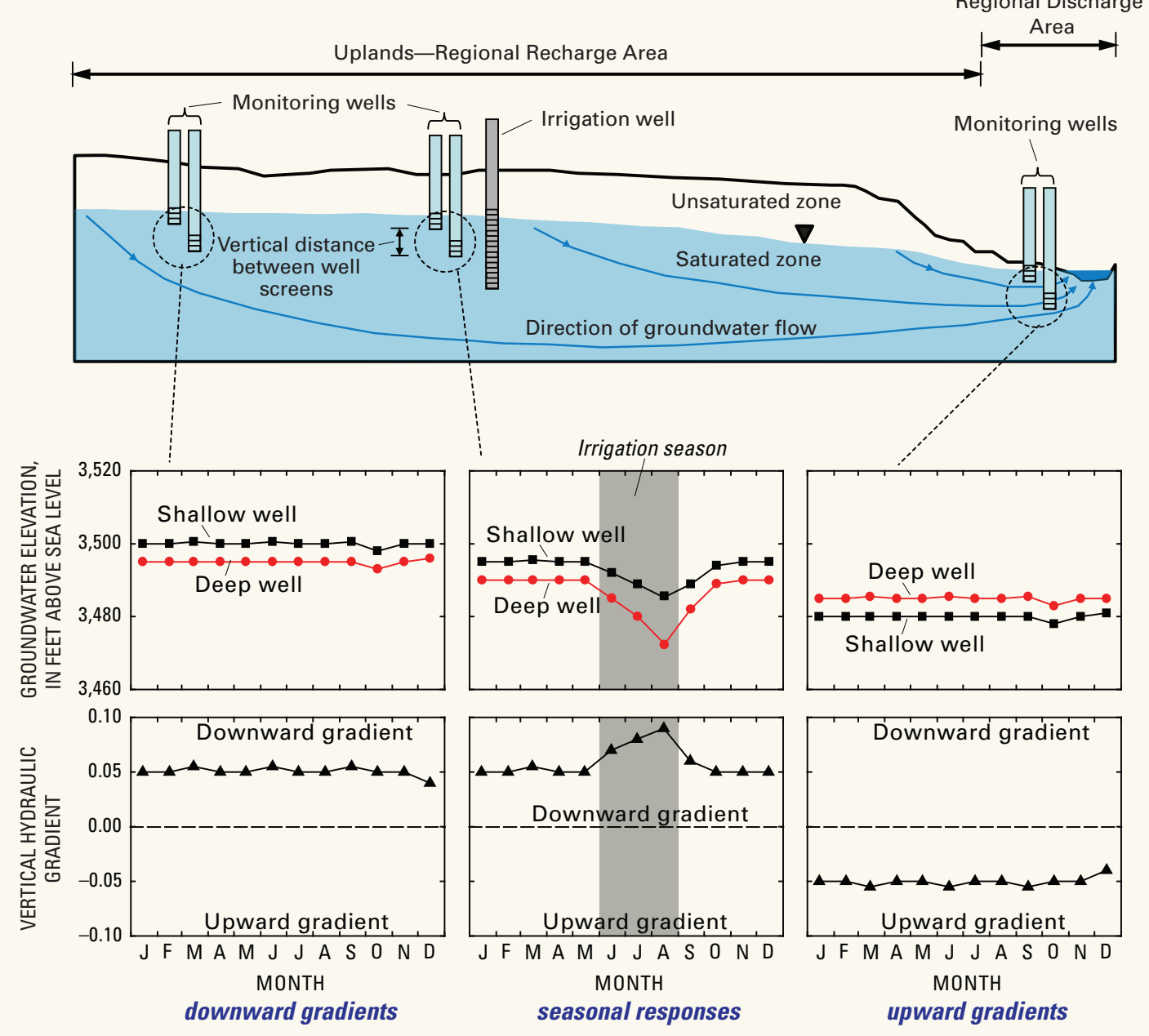

Figure C-1. Three general patterns in vertical hydraulic gradient were observed near the water table in the High Plains aquifer; downward gradients associated with recharge, seasonal responses to nearby pumping wells such as irrigation wells, and upward gradients associated with discharge. Modified from McMahon, Dennehy, and others (2007). 
Groundwater recharged more than 50 years ago accounted for at least 44 to 95 percent (median 70 percent) of the saturated thickness of the High Plains aquifer at the selected regional-transect study locations (fig. 5-1). The apparent groundwater ages at the base of the aquifer for selected regional-transect study locations (fig. 5-1) ranged from about 6,500 years to about 12,500 years. The apparent groundwater ages at the base of the aquifer at all 11 transect sites ranged

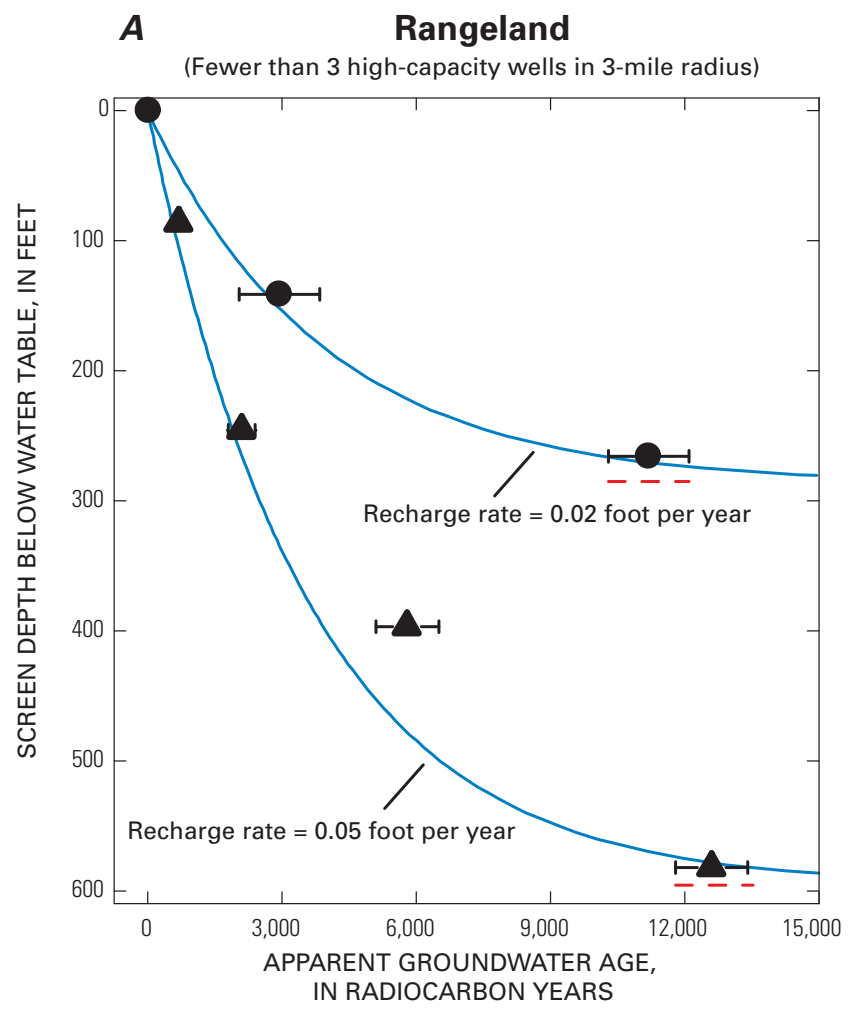

from about 3,400 years in the southern High Plains to 15,600 years in the northern High Plains (McMahon, Böhlke, and Christenson, 2004; McMahon, Böhlke, and Lehman, 2004). These apparent groundwater age estimates indicate that most of the water in the High Plains aquifer at the transect sites consisted of old groundwater that was recharged prior to the onset of modern human activity in the region.
B Irrigated cropland

(More than 10 high-capacity wells in 3-mile radius)

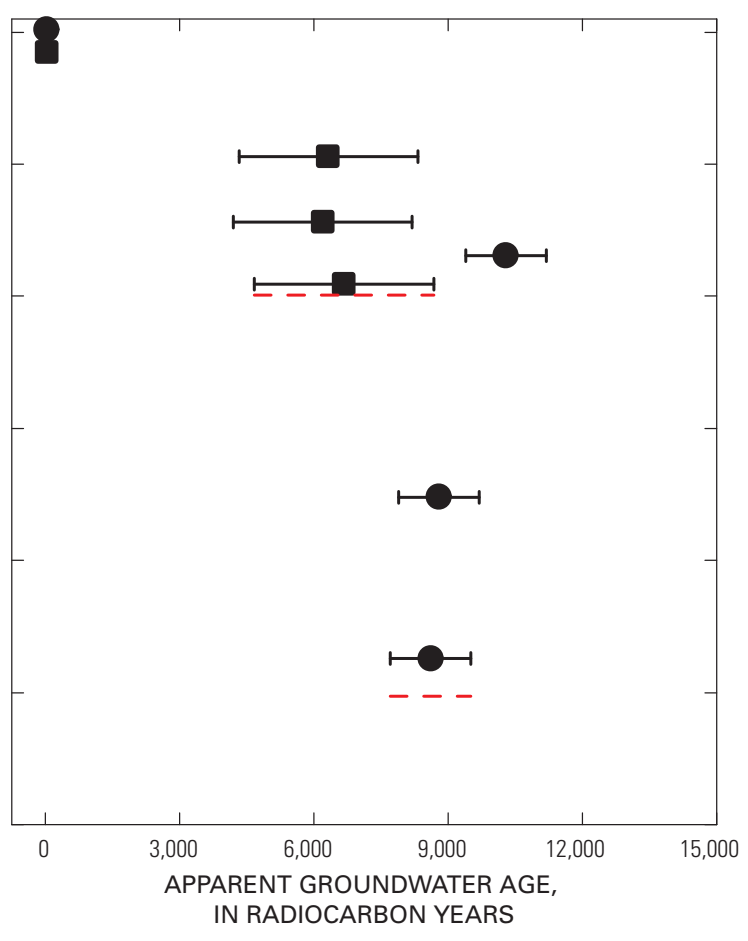

EXPLANATION

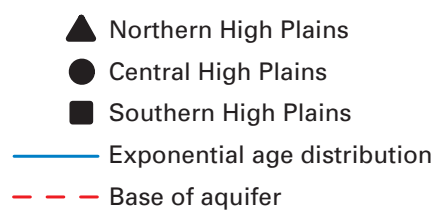

Figure 5-1. Vertical gradients in apparent groundwater age illustrate how the construction and operation of high-capacity irrigation wells with long or multiple screened intervals can mix waters from different depths in the aquifer. For example, in $(A)$, rangeland settings that have few high-capacity wells and a relatively small amount of pumping, the apparent groundwater ages characteristically increase with depth in the aquifer and indicate that relatively young water remains near the water table. However, in $(B)$, irrigated-cropland settings that have numerous high-capacity wells and relatively large amount of pumping, the apparent groundwater ages are more vertically mixed and indicate a greater potential for recently recharged water to move deeper in the aquifer where water-supply wells are more typically screened. Modified from McMahon, Dennehy, and others (2007). 
Concentrations of some important water-quality constituents, such as nitrate and dissolved solids, also systematically change with depth below the water table. For example, nitrate concentrations in groundwater generally decrease with depth below the water table (fig. 5-2). Understanding the relative importance of changing source strength of chemical constituents in recharge and biogeochemical reactions, such as denitrification, in the aquifer is necessary to assess the vulnerability of the deep groundwater to effects on water quality from human activities.

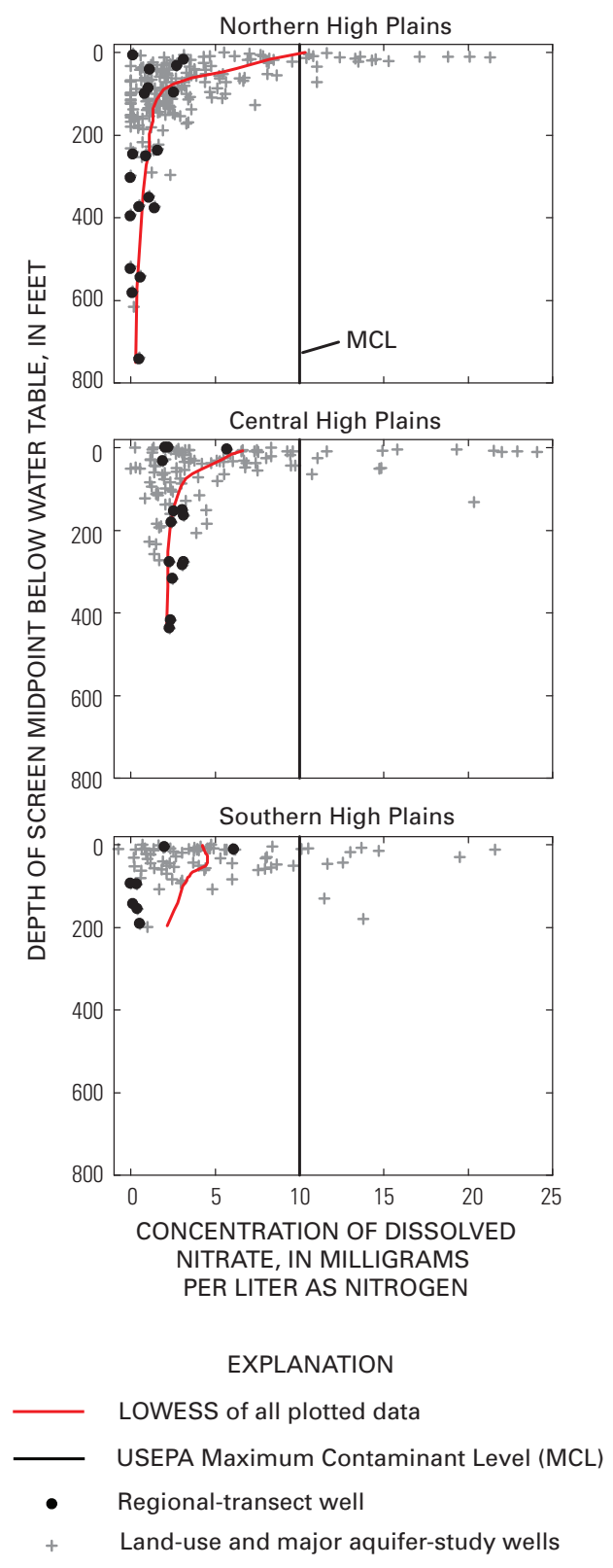

Figure 5-2. Nitrate concentrations decrease with depth below the water table and could be indicative of increasing concentrations of nitrate in recharge over time and (or) degradation along flow paths to deeper locations in the aquifer.
Dissolved-solids concentrations in the aquifer in rangeland or undeveloped areas typically increase gradually with depth below the water table as the residence time of groundwater increases and water/rock interactions progress (fig. 5-3A). However, concentrations of dissolved solids generally decreased with depth below the water table in the vicinity of agricultural land and indicate increased concentrations of dissolved solids in recharge in agricultural areas. Thus, agricultural activity at land surface can increase concentrations of dissolved solids in recharge above what would be expected under natural conditions, resulting in a reversed gradient in dissolved-solids concentration near the water table (fig. 5-3B).

Natural upwelling of saline groundwater from underlying geologic units at the base of the aquifer in regional-discharge zones can cause large increases in dissolved-solids concentrations with depth below the water table (fig. 5-3C). The upwelling could be enhanced by pumping in the aquifer that lowers hydraulic heads and increases the upward-hydraulic gradient across the base of the aquifer (McMahon, Dennehy, and others, 2007). These results indicate that agricultural inputs, natural upwelling, and pumping-enhanced upwelling all have the potential to alter groundwater quality at different depths in the High Plains aquifer.

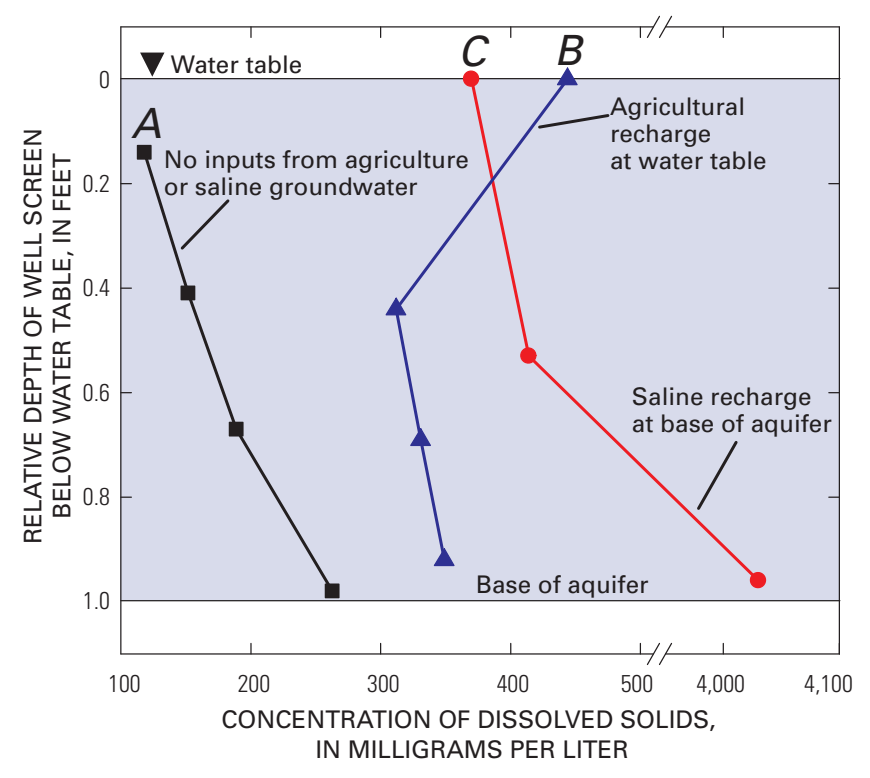

Figure 5-3. Vertical gradients of dissolved-solids concentrations at $(A)$ an undisturbed location generally increase with depth, but can be $(B)$ reversed from what would be expected in undisturbed areas because of agricultural recharge. Natural and pumping-enhanced upwelling of brackish water from underlying units results in $(C)$ substantial increases in dissolved-solids concentrations near the base of the aquifer. 


\section{Processes Affecting Water Quality as it Moves Within the Aquifer}

\section{Reduction-0xidation (Redox)}

Denitrification is the redox process that is most relevant to drinking-water quality in the High Plains aquifer because of widespread high nitrate concentrations (see Chapter 6). Denitrification cannot be relied upon to substantially attenuate nitrate concentrations because it occurs very slowly in most parts of the aquifer. Locally, however, denitrification can be important. Local reducing conditions, possibly associated with organic matter in the aquifer or at clay/sand interfaces, are known to occur in heterogeneous sedimentary aquifers. Specifically, chemical and isotopic data indicate that the Plio-Pleistocene deposits of eastern Nebraska (fig. 2-4) may have sufficient denitrification potential to be an important mechanism for attenuating nitrate concentrations in deeper parts of the aquifer where many of the water-supply wells are screened.

In most parts of the High Plains aquifer, apparent denitrification rates are slow compared to the rates reported for some other aquifer systems and attest to the general lack of nitrateattenuating capacity in the High Plains aquifer (fig. 5-4). The slow denitrification rates have important implications with respect to nitrate concentrations in groundwater recharge that exceed the drinking-water standard; it is estimated that it would take hundreds to thousands of years to lower nitrate concentrations by just $1 \mathrm{mg} / \mathrm{L}$ as N (McMahon, Dennehy, and others, 2006). The results highlight the importance of bestmanagement practices in the High Plains to minimize nitrate concentrations in recharge water. Slow recharge rates and the lack of natural attenuation indicate that once the water in the High Plains aquifer contains elevated nitrate concentrations, those concentrations could remain for a long time.

\section{Water/Rock Interactions}

In general, the primary water/rock interactions that affect the quality of water as it moves through the aquifer are carbonate and silicate mineral dissolution, precipitation of kaolinite and silica, and cation exchange. Such reactions can increase concentrations of dissolved solids in water as it moves along flow paths from recharge areas to points deeper in the aquifer (fig. 5-3A). In addition to contributing major ions such as calcium, sodium, inorganic carbon, sulfate, and silica to solution, these reactions can also contribute trace elements to solution if they are present in the dissolving mineral phases. For example, pyrite commonly contains arsenic, and its dissolution in the presence of oxygen or other oxidants such as nitrate could be a source of arsenic or sulfate in groundwater. The presence of arsenic in groundwater and the possibility of a related drinking-water concern are discussed in Chapter 6.

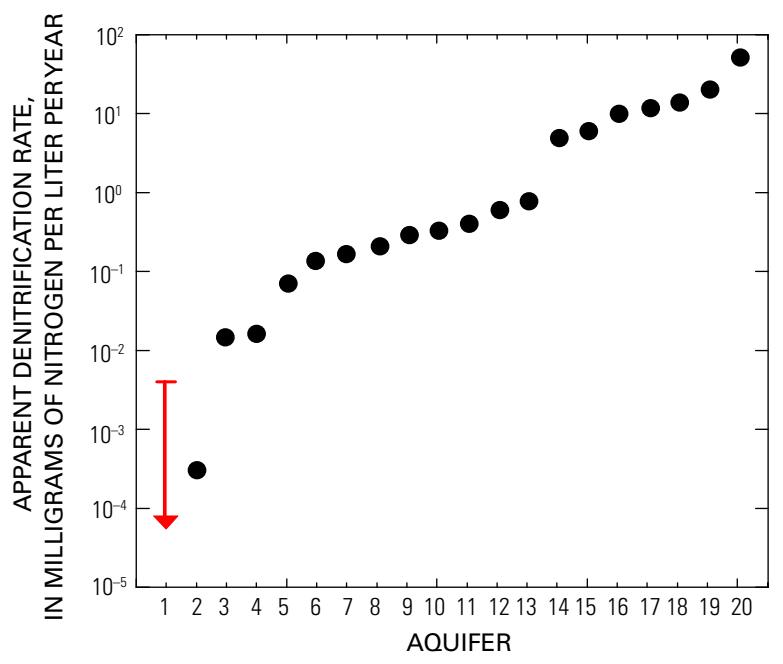

Aquifer

EXPLANATION

(1) High Plains aquifer, Ogallala Formation

(2) Confined sandstone aquifer, Kalahari Desert, Africa

(3) Unconfined alluvial aquifer, Nebraska

(4) North Atlantic Coastal Plain aquifer system, Maryland

(5) Unconfined sand aquifer, Central Valley aquifer, California

(6) Unconfined alluvial aquifer, Colorado

(7) Sand aquifer, Yakima River watershed, Washington

(8) Glacial outwash sand aquifer, Minnesota

(9) Sand aquifer, Delmarva Peninsula, Maryland

(10) North Atlantic Coastal Plain aquifer system, North Carolina

(11) Sand aquifer, Elkhorn River watershed, Nebraska

(12) Sand aquifer, San Joaquin River watershed, California

(13) Floridan aquifer system, Florida

(14) Shale confining unit, Colorado

(15) Unconfined sand aquifer, flood plain, Nebraska

(16) Unconfined sand aquifer, Germany

(17) Sand aquifer, Central Valley aquifer, California

(18) Clayey till, Nebraska

(19) Confined limestone aquifer, United Kingdom

(20) Unconfined glacial outwash sand aquifer, Canada

- Maximum reported value

I Range indicating a "less than" value

Figure 5-4. The apparent denitrification rates of the High Plains aquifer are substantially less than rates in many other aquifer systems (summarized from Green and others [2008] and Groffman and others [2006]) and indicate that nitrate, once present, will remain in the High Plains aquifer for a long time. These findings support the need for emphasis on best-management practices that reduce the concentration of nitrate in recharge water. 


\section{Mixing}

Although redox processes and water/rock interactions likely occur throughout the High Plains aquifer, mixing can also occur, particularly at local or subregional scales. Mixing is likely the most important process in areas with the greatest density of irrigation or other supply wells and in regional discharge areas. Mixing with surface water, mixing with groundwater from geologic units underlying the High Plains aquifer, and vertical mixing within the aquifer because of well pumping or leakage through long or multiple well screens all have the potential to affect water quality in the aquifer.

Groundwater/surface-water mixing is likely a common occurrence in major river valleys of the High Plains, such as the Arkansas River valley (fig. 2-1) (Whittemore, 2002), because the alluvial sediments are important sources of water for irrigation and public supply. Pumping groundwater from alluvial sediments can draw river water into the High Plains aquifer and affect concentrations of sulfate, pesticides, and other constituents in the aquifer, as indicated in regionaltransect studies in Kansas and Nebraska.

Substantial introduction of surface water into alluvial aquifers also occurs in areas receiving surface-water irrigation. For example, the alluvial aquifer along the Platte River in western Nebraska is recharged primarily by infiltration of river-derived water beneath unlined canals (low nitrate, high uranium concentrations) and beneath the irrigated fields (high nitrate, high uranium concentrations) (Böhlke and others, 2007).

Mixing by wells may also accelerate the upward movement of saline water from underlying formations. In the central High Plains, for example, halite-dissolution brines with dissolved-chloride concentrations up to $35,000 \mathrm{mg} / \mathrm{L}$ were present in geologic units underlying the aquifer and contribute about 5 percent of the water at the base of the High Plains aquifer in the regional-discharge area of the Cimarron River valley (McMahon, Böhlke, and Christenson, and others, 2004).

Mixing is also caused by leakage through long or multiple well screens and by long-term pumping of high-capacity public-supply and irrigation wells. Mixing caused by leakage (or short-circuiting, see Box $D$ ) and pumping is a major process for moving chemical constituents from near the water table to deeper zones more rapidly than would occur otherwise under natural hydraulic gradients. Thus, human activity is not only a source of chemical constituents to the water table, but it also appears to enhance their transport once they are in the aquifer. 


\section{Box Thort Circuiting of Multiscreened Wells Increases Groundwater Vulnerability to Contamination}

Sandra Eberts, ${ }^{1}$ Brian Clark$^{2}$ Matthew Landon, ${ }^{3}$ and Martha L. Jagucki ${ }^{1}$

Well-construction methods used in development of the High Plains aquifer to supply large quantities of irrigation and drinking water have, in locations such as York, Nebraska (figure $D-1$ ), introduced short-circuit pathways that adversely affect the quality of groundwater produced by public-supply wells.

Multiscreened wells are irrigation, commercial, and public-supply wells that have well screens across the unconfined and confined aquifers to maximize yields (see irrigation well in figure $D-1$ ). Multiscreened wells offer conduits for downward movement of water and contaminants when the well is not in use (see inactive well in figure $D-1$ ). The movement along this short-circuit path is years to centuries faster than flow of water through the confining unit. During periods when a multiscreened well is not pumped (usually during the fall, winter, and spring for irrigation wells), contaminants that flow down the well and out of the well screen in the confined aquifers may travel beyond the capture zone of the well before pumping is resumed and affect the quality of water produced by downgradient public-supply wells (see public-supply well in figure $D-1$ ).

Additional details on the human activities, natural processes, and pathways that affect public-supply well vulnerability to contamination are outlined by Clark and others (2008), Jagucki and others (2008), Landon and others (2008), Landon and Turco (2007), and Eberts and others (2005).

High Plains aquifer near York, Nebraska
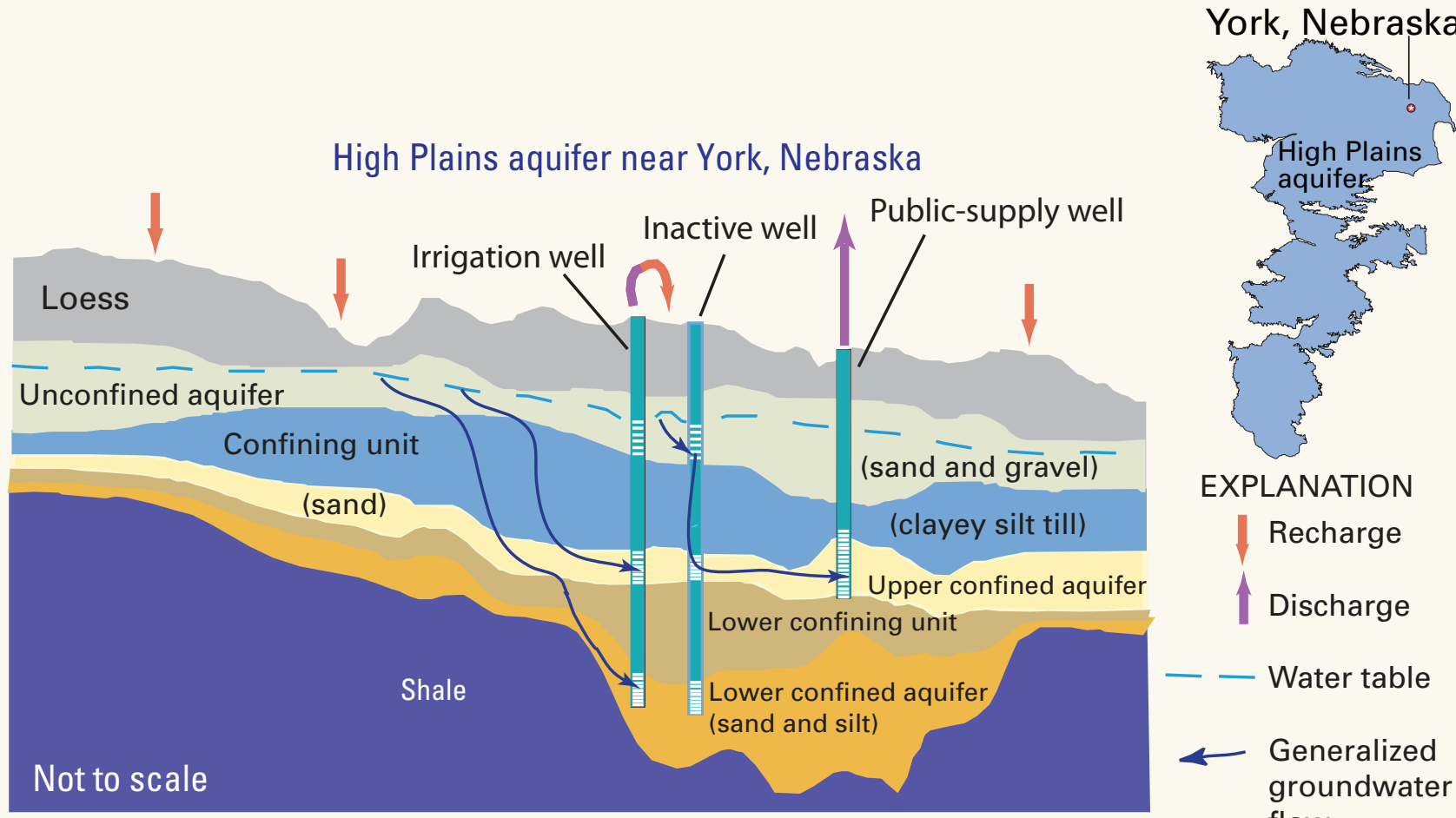

EXPLANATION

Recharge

Discharge

- Water table

Generalized groundwater flow

Figure D-1. Conceptual model of groundwater flow and short circuits for contaminants to public-supply wells near York, Nebraska (modified from Jagucki and others, 2008).

\footnotetext{
${ }^{1}$ U.S. Geological Survey, Columbus, Ohio.

${ }^{2}$ U.S. Geological Survey, Little Rock, Arkansas.

${ }^{3}$ U.S. Geological Survey, San Diego, California.
} 


\section{Quality of the Resource Used for Drinking and Irrigation-What Was Found, Where, and Why}

The quality of deeper water in the High Plains aquifer, where private, public-supply, and irrigation wells typically are screened, directly affects the "used" resource. The used resource assessed in this chapter includes water consumed by humans and crops and, to a lesser extent, livestock. Irrigated crops receive the largest amount of water from the High Plains aquifer. Data from the major-aquifer studies and existing data compiled from public-supply and irrigation wells are used to assess the used groundwater resource.

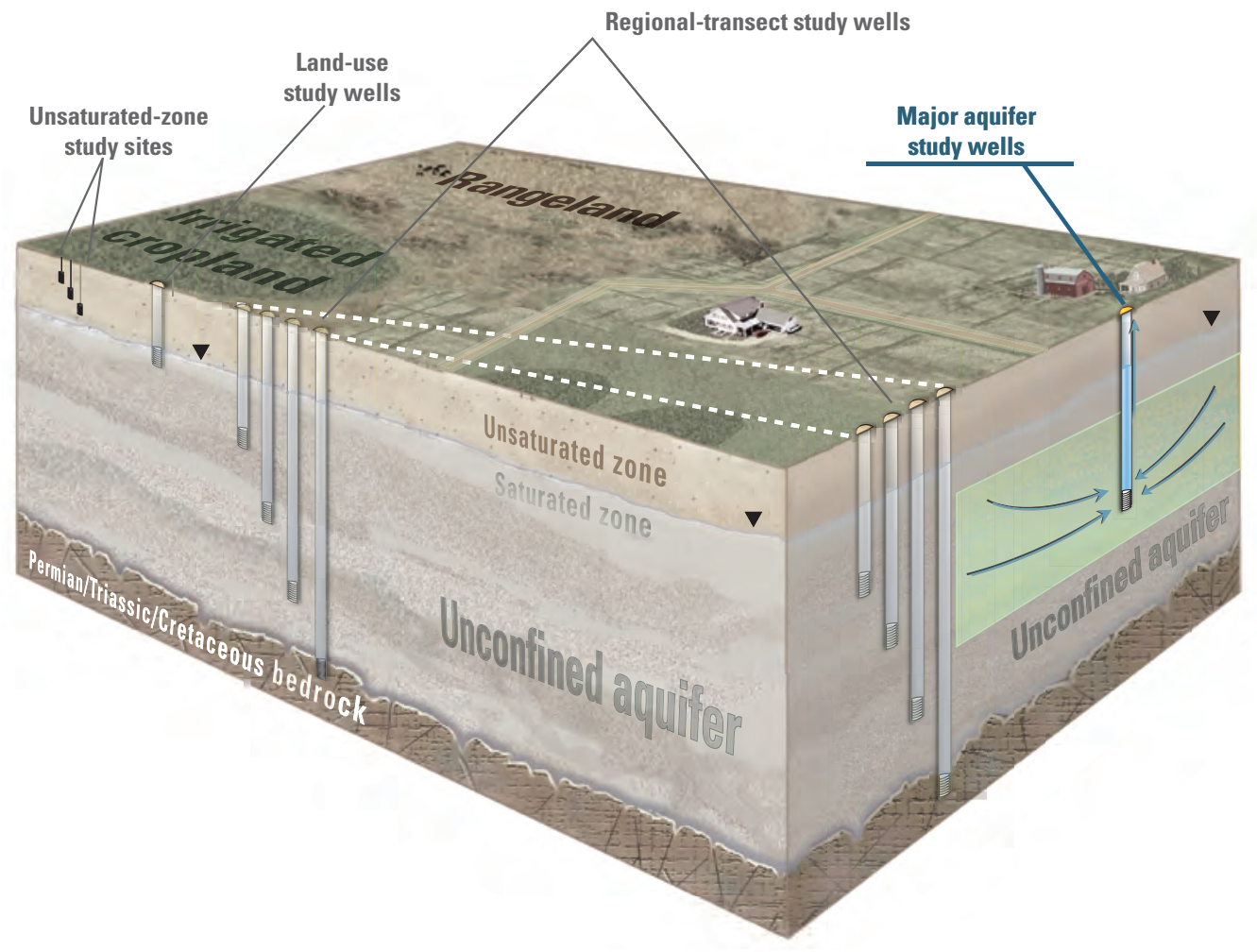

This chapter summarizes the quality of water that might be consumed by humans and irrigated crops, and to a lesser extent livestock, through their use of water from private, public-supply, and irrigation wells. 


\section{General Findings-Quality of the Used Resource}

The water produced by private, public-supply, and irrigation wells in the High Plains generally is of suitable quality relative to the U.S. Environmental Protection Agency's Maximum Contaminant Level (MCL) or Secondary Maximum Contaminant Level (SMCL) (U.S. Environmental Protection Agency, 2009) for drinking water. However, some spatial differences in water quality are observed. The northern part of the Ogallala Formation has the best water quality (fig. 6-1), based on data from private wells that were sampled for the major-aquifer studies and in terms of various water-quality standards. The southern part of the Ogallala Formation has the poorest water quality (fig. 6-1), with elevated concentrations of chloride, fluoride, manganese, dissolved solids, arsenic, nitrate, and uranium greater than the MCL or SMCL. The observed water-quality differences between hydrogeologic units are attributed to many human and natural factors, including pumping rates, irrigation density, pesticide and nitrogen applications, climate, depth to water (below land surface), saturated thickness of the aquifer, well screen depth below the water table, redox conditions, and mixing.

The changing quality of groundwater recharge during the past 50 to 60 years and transport processes in the High Plains aquifer have resulted in small but measurable increases in concentrations of human contaminants in water-supply wells. This is illustrated by comparing nitrate concentrations in High Plains groundwater since the 1930s. Median nitrate concentrations in groundwater were similar from the 1930s to the 1960s, somewhat larger in the 1970s, and significantly larger yet in the 1980s and 1990s (fig. 6-2). The trend becomes even more apparent when viewed in the context of a millennial timeframe (fig. 4-6). This type of long-term gradual increase in groundwater nitrate concentrations is an example of the concept called "creeping normalcy" (Fogg and LaBolle, 2006) because the gradual increase generally is hard to separate from the background when viewed in the context of short timeframes.

An implication of the trend data observed in water from supply wells of the High Plains aquifer is that some constituent concentrations in the used resource will continue to increase in the future as the fraction of recent recharge captured by supply wells increases. The upward nitrate trend could limit groundwater sustainability given current uses and therefore is an important factor for water-availability planning and future management.

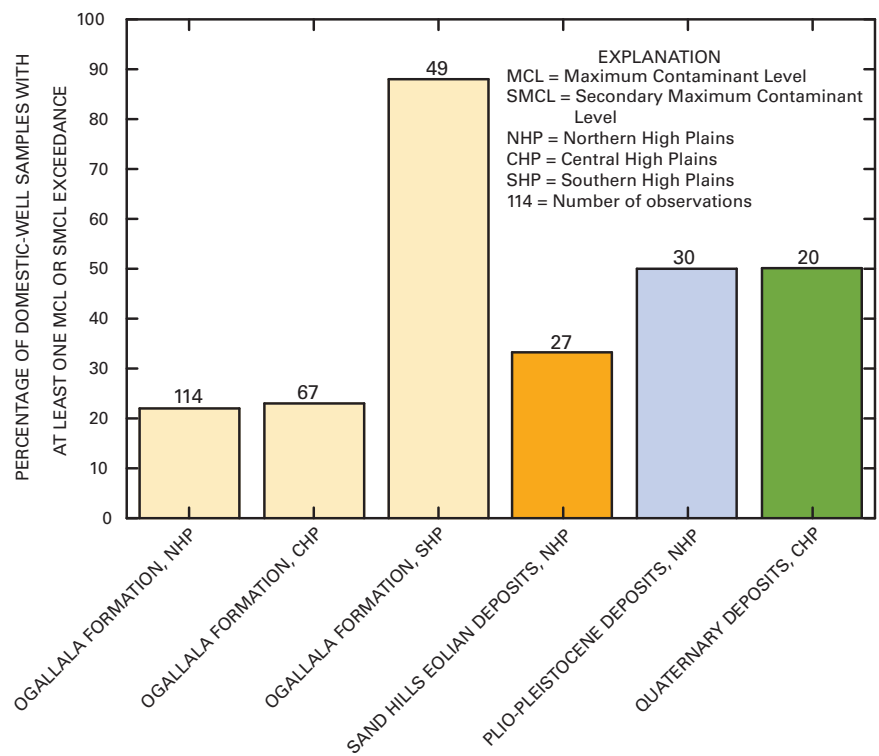

Figure 6-1. Comparison of overall water quality in assessed hydrogeologic units of the High Plains aquifer based on water samples collected from private wells and in terms of various water-quality standards (modified from McMahon, Dennehy, and others, 2007). Note: The bar colors correspond to the hydrogeologic units in figure $2-4$.

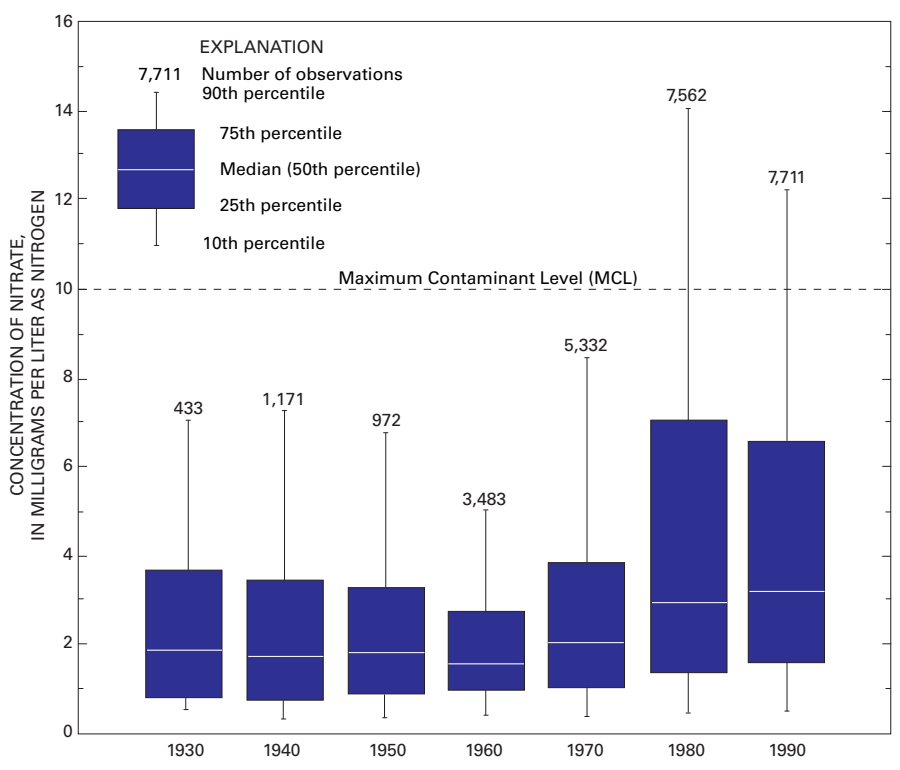

Figure 6-2. A "creeping normalcy" over time of nitrate concentrations in water from supply wells may limit the sustainability of the aquifer as a source of drinking water (modified from Litke, 2001). 


\section{Private Wells}

Water-quality conditions in the High Plains aquifer reported for private wells are based on samples collected from 307 randomly distributed private wells as part of the majoraquifer studies. The results for the samples from private wells are an indicator of the broad range of water-quality conditions within each hydrogeologic unit.

Water quality generally is good, as indicated by comparisons to SMCLs and MCLs (fig. 6-1). Median concentrations did not equal or exceed the SMCLs in any of the hydrogeologic units except for dissolved solids in the southern part of the Ogallala Formation. The fact that water in this part of the Ogallala Formation had a median concentration of dissolved solids that exceeded the SMCL highlights the general northto-south increase in concentrations of several of the major ions and focuses some concern regarding water-quality issues in the southern High Plains. Many of the factors controlling the high dissolved-solids concentrations occur naturally, including smaller saturated thicknesses than many other units in the High Plains aquifer and regional climate gradients in the High Plains that resulted in larger evapotranspiration rates in the south. Those conditions, coupled with the fact that some bedrock units underlying the southern part of the High Plains (and parts of the central part) have large amounts of soluble minerals that could contribute dissolved solids to water near the bottom of the aquifer, contribute to the observed regional differences in dissolved-solids concentrations. Superimposed on these largely natural factors are regional differences in land-use practices that affect recharge chemistry.

Arsenic may present a drinking-water concern because of its detection frequencies and concentrations. Arsenic concentrations equaled or exceeded the 10 micrograms per liter $(\mu \mathrm{g} / \mathrm{L}) \mathrm{MCL}$ in at least one water sample from all hydrogeologic units with the exception of the central Ogallala Formation. The greatest percentage of arsenic MCL exceedances occurred in the southern part of the Ogallala Formation (nearly 30 percent) (fig. 6-3). The sources of arsenic in the High Plains aquifer are, in large part, naturally occurring; possible natural sources include marine shale in underlying bedrock units, volcanic-ash deposits in the aquifer, iron-oxide grain coatings on aquifer sediments, pyrite in the aquifer, and saline lakes. A possible human source of arsenic in the southern High Plains could be the historical use of arsenic acid as a cotton defoliant along with the application of arsenical pesticides or other arsenic-bearing fertilizers (Scanlon, 2006). However, based on land-use/land-cover distribution and arsenic profiles in the unsaturated zone, Scanlon (2006) concluded that surface application of arsenic was not the primary source of arsenic to groundwater in the southern High Plains.
Private wells in the aquifer generally supply suitable drinking water with respect to nitrate. Overall, only 5 percent of the samples from private wells had nitrate concentrations that equaled or exceeded the MCL of $10 \mathrm{mg} / \mathrm{L}$ as $\mathrm{N}$.

Nitrate concentrations in water from private wells increased significantly from north to south in the High Plains, which is opposite the pattern that was observed for nitrate concentrations in recently recharged water beneath irrigated cropland. Higher concentrations of nitrate in water from private wells in the central and southern parts (fig. 6-4) most likely relate to the greater presence of dissolved oxygen in the vicinity of measured wells (less denitrification); more intensive well pumping for irrigation or public supply that vertically mixes the water and accelerates the movement of recent recharge, presumably containing relatively large nitrate concentrations, deeper in the aquifer; smaller saturated thickness of the aquifer; well screens closer to the water table; smaller depth to water; and a lack of fine-grained confining layers to isolate deep water-bearing layers from surface contamination.

At least one of the 44 measured pesticide compounds was detected in water from each of the hydrogeologic units, with detection frequencies ranging from 5.3 to 30 percent (fig. 6-5). One or more pesticide compounds were detected in about 14 percent of private wells. Atrazine, a herbicide commonly used on corn, and its degradation product, deethylatrazine, were the most frequently detected compounds in each of the hydrogeologic units. Concentrations were low; all of the pesticide-compound concentrations were less than $2 \mu \mathrm{g} / \mathrm{L}$, and none of them equaled or exceeded an MCL, although only 2 of the 12 detected compounds had MCLs. Nine of the 12 detected pesticide compounds in water were among the 14 most commonly detected compounds in the Nation's groundwater beneath agricultural land-use areas (Gilliom and others, 2006). This group of compounds listed for the Nation is characterized by extensive agricultural use and relatively high mobility and (or) persistence in the environment.

Volatile organic compounds (VOCs) were detected in about 5 percent of the sampled wells, which is about three times less than the detection frequency for pesticides. This finding is consistent with the predominance of agriculture over urban land uses in the High Plains, assuming that most VOC sources occur in urban settings. Ten of the 85 measured VOCs were detected. All of the detected concentrations were low, and none exceeded an MCL. The trihalomethane compound chloroform was one of the most commonly detected VOCs, which is consistent with results for private-well samples from across the Nation (Zogorski and others, 2006). The relatively common occurrence of chloroform in the private-well samples may be related in part to redox conditions in the aquifer and the fact that chloroform is relatively stable in oxic groundwater (McMahon, Dennehy, and others, 2007). 


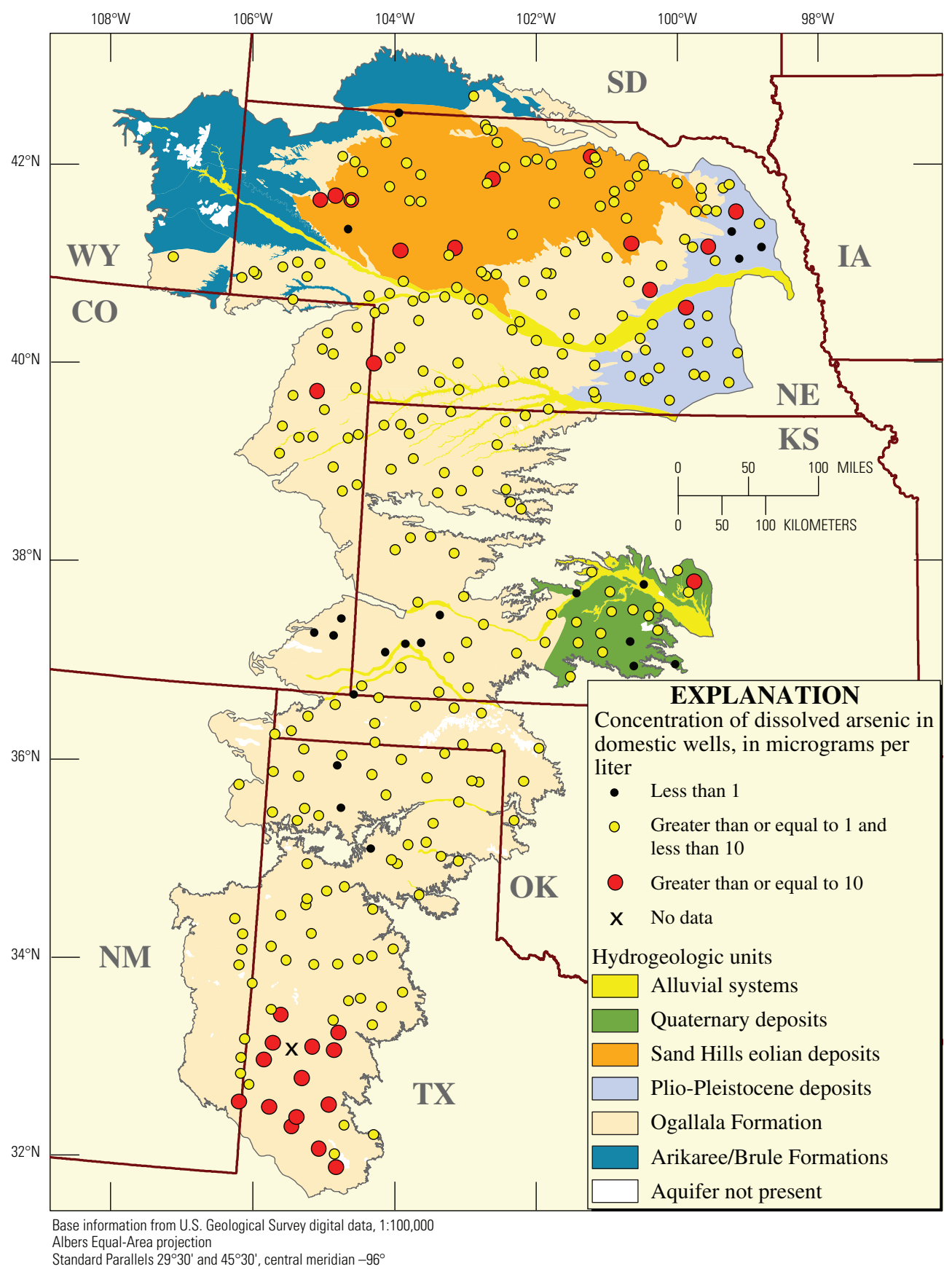

Figure 6-3. At least one groundwater sample from private wells screened in each hydrogeologic unit, except the central Ogallala Formation, Arikaree/Brule Formation, and Alluvial systems, contained arsenic concentrations that equaled or exceeded the U.S. Environmental Protection Agency's Maximum Contaminant Level (MCL) of 10 micrograms per liter for drinking water (U.S. Environmental Protection Agency, 2009). 


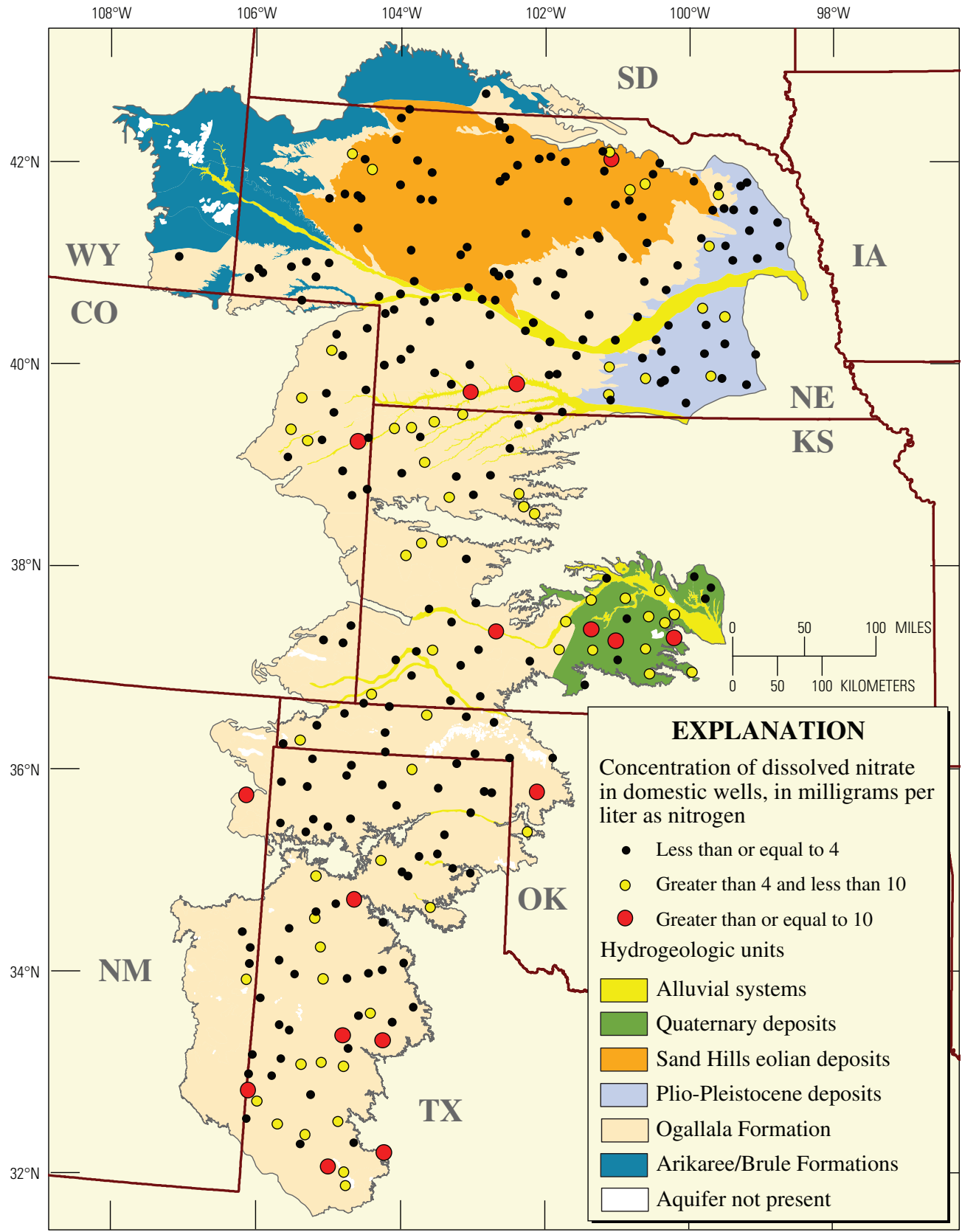

Base information from U.S. Geological Survey digital data, 1:100,000 Albers Equal-Area projection

Standard Parallels $29^{\circ} 30^{\prime}$ and $45^{\circ} 30^{\prime}$, central meridian $-96^{\circ}$

Figure 6-4. About 5 percent of water samples from private wells contained nitrate concentrations that equaled or exceeded the U.S. Environmental Protection Agency's Maximum Contaminant Level (MCL) of 10 milligrams per liter as nitrogen for drinking water (U.S. Environmental Protection Agency, 2009). A much larger percentage of water samples from private wells contained nitrate greater than 4 milligrams per liter as nitrogen, which is considered the natural background concentration for the High Plains aquifer. 


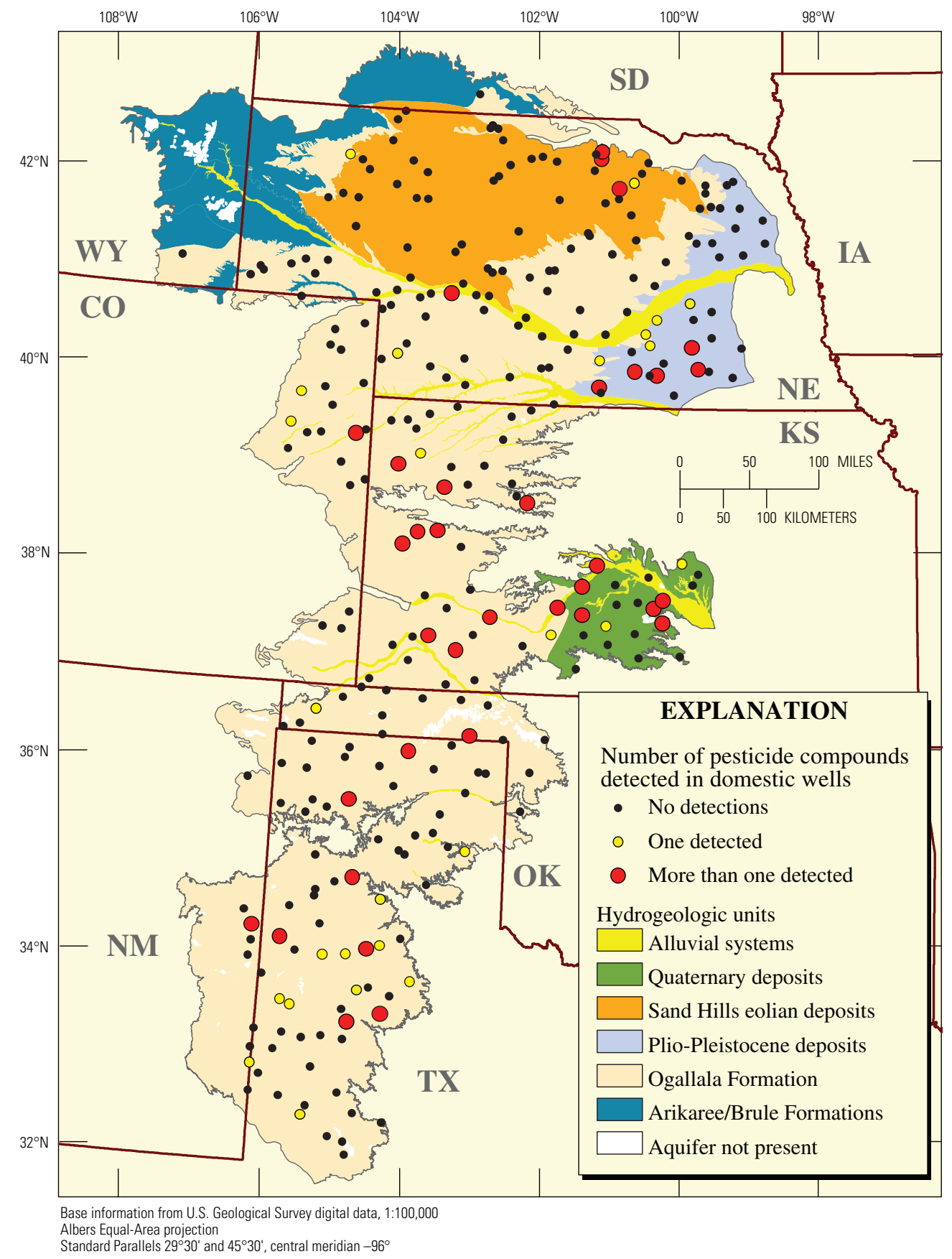

Figure 6-5. About 14 percent of water samples from private wells contained at least one pesticide compound. Atrazine and its degradation product deethylatrazine were the most frequently detected pesticide compounds in water from the private wells. 


\section{Public-Supply Wells}

Water-quality conditions reported for public-supply wells are based on existing data from 101 wells located in the PlioPleistocene deposits in Nebraska and throughout the Ogallala Formation.

The quality of water from the public-supply wells is generally similar to that of private wells, including north-to-south variations in major-ion chemistry that generally are attributed to regional differences in underlying bedrock geology, climate, aquifer mineralogy, land use, and hydrologic features such as saline lakes (McMahon, Dennehy, and others, 2007).

Significant differences were noted only in dissolvedsolids concentrations; specifically, water samples from publicsupply wells in the northern part of the aquifer contained significantly greater concentrations than samples from the private wells. Data collected from this study does not support a conclusive reason for the differences in dissolved-solids concentrations between public-supply and private wells.

Based on a small subset of paired public-supply and private wells (15 pairs in the Ogallala Formation of the central High Plains), water from public-supply wells had more pesticide detections and more tritium concentrations greater than 0.5 tritium unit (indicating younger water), probably because of mixing resulting from longer or multiple screens, higher pumping rates, and longer pumping periods for the publicsupply wells. This finding strongly supports the conclusion that leakage through wells with long or multiple screens and long-term pumping of high-capacity wells such as publicsupply and irrigation wells are important mechanisms for moving contaminants downward from the water table more quickly than would occur naturally in the High Plains aquifer (McMahon, Böhlke, and others, 2008; McMahon, Burow, and others, 2008) (see Box D).

\section{Irrigation Wells}

Irrigated crops receive the largest amount of water pumped from the High Plains aquifer. Groundwater quality from irrigation wells can have positive or adverse effects on crop yield. Salinity, reduced water infiltration at the land surface, and boron toxicity have the potential to reduce crop yield. Nitrogen in irrigation water potentially can increase crop yield and (or) reduce production costs. Water-quality data reported by other agencies for irrigation wells were assembled for 131 wells in the Plio-Pleistocene deposits in Nebraska and the Ogallala Formation (McMahon, Dennehy, and others, 2007).

Elevated salinity in irrigation water is greatest in the southern part of the Ogallala Formation, in which 3 percent of samples had dissolved-solids concentrations in excess of $2,000 \mathrm{mg} / \mathrm{L}$, indicating severe salinity restrictions if the water is used for irrigation. No salinity restrictions were exceeded for samples from the northern part of the Ogallala Formation. About half of the samples from the central and southern parts could be characterized as having slight to moderate salinity with restrictions on the use of irrigation water (McMahon, Dennehy, and others, 2007).

Low salinity can also be a water-quantity issue in irrigation water because it can ultimately reduce water infiltration at the land surface. Specifically, water with low salinity can leach surface soils of soluble minerals and salts that stabilize soil aggregates and soil structure, allowing finer soil particles to fill pore spaces in the upper soil zones and reduce rates of water infiltration. Soil mineral leaching did not seem to be an issue in the High Plains; only one sample was identified to have the potential to severely limit infiltration (table 1 and fig. 6-6). Most of the assessed irrigation water was classified as having slight to moderate potential to reduce infiltration rates.

Table 1. Salinity and boron toxicity are not a concern from irrigation well water of the Ogallala Formation. $[\mathrm{mg} / \mathrm{L}$, milligrams per liter; $\mu \mathrm{g} / \mathrm{L}$, micrograms per liter; $\mathrm{n}$, number of samples; <, less than; >, greater than]

\begin{tabular}{|c|c|c|c|c|}
\hline \multirow[b]{2}{*}{ Potential irrigation problem } & \multirow{2}{*}{$\begin{array}{l}\text { General water-quality } \\
\text { criteria }^{1}\end{array}$} & \multicolumn{3}{|c|}{ Ogallala Formation (percentage of samples in each category) } \\
\hline & & Northern High Plains & $\begin{array}{l}\text { Central High } \\
\text { Plains }\end{array}$ & $\begin{array}{l}\text { Southern High } \\
\text { Plains }\end{array}$ \\
\hline \multicolumn{5}{|l|}{ Salinity } \\
\hline Dissolved solids & $\mathrm{mg} / \mathrm{L}$ & $\mathrm{n}=13$ & $\mathrm{n}=34$ & $\mathrm{n}=30$ \\
\hline None & $<450$ & 100 & 59 & 40 \\
\hline Slight to moderate & $450-2,000$ & 0 & 41 & 57 \\
\hline Severe & $>2,000$ & 0 & 0 & 3 \\
\hline \multicolumn{5}{|l|}{ Boron toxicity } \\
\hline Boron concentration & $\mu \mathrm{g} / \mathrm{L}$ & $\mathrm{n}=9$ & $\mathrm{n}=29$ & $\mathrm{n}=21$ \\
\hline None & $0-700$ & 100 & 100 & 100 \\
\hline Slight to moderate & $700-3,000$ & 0 & 0 & 0 \\
\hline Severe & $>3,000$ & 0 & 0 & 0 \\
\hline
\end{tabular}

${ }^{1}$ From Ayers and Wescot (1994). 
Toxicity effects occur in plants if certain constituents, such as boron, in irrigation water are present in concentrations large enough to cause crop damage or reduce yield (Ayers and Wescot, 1994). None of the irrigation-water samples in this study contained boron concentrations that are toxic to crops commonly grown in the High Plains (table 1).

Nitrogen in most of the samples represents less than 20 percent of the nitrogen requirement for irrigated corn in the
High Plains. Nevertheless, the amount could be important from a water-quality perspective if producers were to reduce applications at the land surface by a similar amount. Nitrate concentrations deeper in the High Plains aquifer are likely to increase over time as nitrate in the thick unsaturated zones reaches the water table and as irrigation pumping vertically redistributes nitrate throughout the aquifer. Thus, nitrogen concentrations (or credits) in irrigation water could increase over time and help to increase crop yield and (or) reduce production costs.

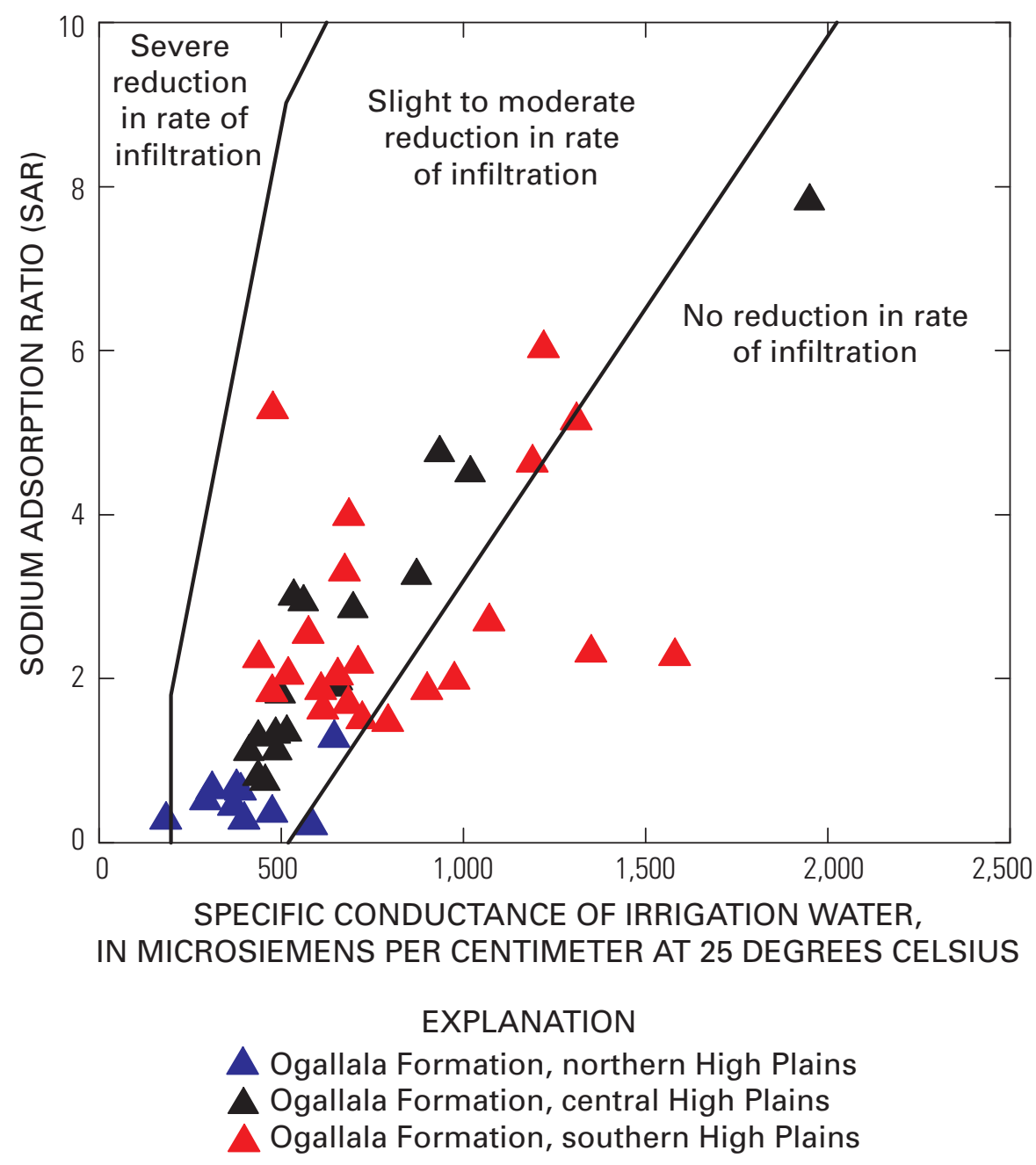

Figure 6-6. Most of the irrigation waters sampled have a slight to moderate potential to reduce water infiltration (modified from Ayers and Wescot, 1994). 


\section{References Cited}

The High Plains aquifer study publications are shown in bold type.

Alley, W.M., 2006, Tracking U.S. ground water-Reserves for the future?: Environment, v. 49, p. 11-29.

Alley, W.M., Reilly, T.L., and Franke, O.H., 1999, Sustainability of ground-water resources: U.S. Geological Survey Circular 1186, 79 p.

Ayers, R.S., and Wescot, D.W., 1994, Water quality for agriculture: Food and Agriculture Organization irrigation and drainage paper no. 29 Rev. 1, ISBN 92-5-102263-1, 174 p.

Böhlke, J.J., Verstraeten, I.M., and Kraemer, T.F., 2007, Effects of surface-water irrigation on sources, fluxes, and residence times of water, nitrate, and uranium in an alluvial aquifer: Applied Geochemistry, v. 22, p. 152-174.

Bruce, B.W., Becker, M.F., Pope, L.M., and Gurdak, J.J., 2003, Ground-water quality beneath irrigated agriculture in the central High Plains aquifer, 1999-2000: U.S. Geological Survey Water-Resources Investigations Report 2003-4219, 39 p.

Claborn, B. J., Urban, L.V., and Oppel, S.E., 1985, Frequency of significant recharge to the Ogallala Aquifer from playa lakes: Water Resource Center, Project Number G-935-03, $24 \mathrm{p}$.

Clark, B.R., Landon, M.K., Kauffman, L.J., and Hornberger, G.Z., 2008, Simulations of ground-water flow, transport, age, and particle tracking near York, Nebraska, for a study of transport of anthropogenic and natural contaminants (TANC) to public supply wells: U.S. Geological Survey Scientific Investigations Report 2007-5068, 48 p.

Coplen, T.B., Hopple, J.A., Böhlke, J.K., Peiser, H.S., Rieder, S.E., Krouse, H.R., Rosman, K.J.R., Ding, T., Vocke, R.D., Revesz, K.M., Lamberty, A., Taylor, P., and De Bievre, P., 2002, Compilation of minimum and maximum isotope ratios of selected elements in naturally occurring terrestrial materials and reagents: U.S. Geological Survey WaterResources Investigations Report 2001-4222, 98 p.

Dennehy, K.F., Litke, D.W., and McMahon, P.B., 2002, The High Plains aquifer; USA - Groundwater development and sustainability, in Hiscock, K.M., Rivett, M.O., and Davison, R.M., eds., Sustainable groundwater development: London Geological Society, Special Publication 193, p. 99-119.
Eberts, S.M., Erwin, M.L., and Hamilton, P.A., 2005, Assessing the vulnerability of public-supply wells to contamination from urban, agricultural, and natural sources: U.S. Geological Survey Fact Sheet 2005-3022.

Fogg, G.E., and LaBolle, E.M., 2006, Motivation of synthesis, with an example on groundwater quality sustainability: Water Resources Research, v. 42, W03S05, doi:10.1029/2005WR004372.

Gilliom, R.J., Barbash, J.E., Crawford, C.G., Hamilton, P.A., Martin, J.D., Nakagaki, N., Nowell, L.H., Scott, J.C., Stackelberg, P.E., Thelin, G.P., and Wolock, D.M., 2006, Pesticides in the Nation's streams and ground water, 1992-2001: U.S. Geological Survey Circular 1291, 172 p.

Green, C.T., Puckett, L.J., Böhlke, J.K., Bekins, B.A., Phillips, S.P., Kauffman, L.J., Denver, J.M., and Johnson, H.M., 2008, Limited occurrence of denitrification in four shallow aquifers in agricultural areas of the United States: Journal of Environmental Quality 37, 994-1009, doi:10.2134/jeq2006.0419.

Groffman, P.M., Altabet, M.A., Böhlke, J.K., ButterbachBahl, K., David, M.B., Firestone, M.K., Giblin, A.E., Kana, T.M., Nielson, L.P., and Voytek, M.A., 2006, Methods for measuring denitrification-Diverse approaches to a difficult problem: Ecological Applications, v. 16, no. 6, p. 2091-2122.

Gurdak, J.J., 2008, Groundwater vulnerability: Nonpoint-source contamination, climate variability, and the High Plains aquifer: Saarbrucken, Germany, VDM Verlag Publishing, ISBN: 978-3-639-09427-5, 223 p.

Gurdak, J.J., Hanson, R.T., McMahon, P.B., Bruce, B.W., McCray, J.E., Thyne, G.D., and R.C. Reedy, 2007, Climate variability controls on unsaturated water and chemical movement, High Plains aquifer, USA: Vadose Zone Journal, doi: 10.2136/vzj/2006.0087.

Gurdak, J.J., McCray, J.E., Thyne, G.D., and Qi, S.L., 2007, Latin hypercube approach to estimate uncertainty in groundwater vulnerability: Groundwater, v. 45, no. 3, p. 348-361, doi: 10.1111/j.17456584.2006.00298.x.

Gurdak, J.J., and Qi, S.L., 2006, Vulnerability of recently recharged ground water in the High Plains aquifer to nitrate contamination: U.S. Geological Survey Scientific Investigations Report 2006-5050, 39 p.

Gurdak, J.J., Walvoord, M.A., and McMahon, P.B., 2008, Susceptibility to enhanced chemical migration from depression-focused preferential flow, High Plains aquifer: Vadose Zone Journal, v. 7, no. 4, p. 1172-1184, doi: 10.2136/vzj2007.0145. 
Jagucki, M.L., Landon, M.K., Clark, B.R., and Eberts, S.M., 2008, Assessing the vulnerability of public supply wells to contamination-High Plains aquifer near York, Nebraska: U.S. Geological Survey Fact Sheet 2008-3025, 6 p.

Landon, M.K., Clark, B.R., McMahon, P.B., McGuire, V.L., and Turco, M.J., 2008, Hydrogeology, chemical characteristics, and transport processes in the zone of contribution of a public-supply well in York, Nebraska: U.S. Geological Survey Scientific Investigations Report 2008-5050, 149 p.

Landon, M.K., and Turco, M.J., 2007, Hydrogeologic setting and ground water flow simulation of the Eastern High Plains Regional Study Area, Nebraska, in Paschke, S.S., ed., Hydrogeologic settings and ground-water flow simulations for regional studies of the transport of anthropogenic and natural contaminants to publicsupply wells-Studies begun in 2001: Reston, Va., U.S. Geological Survey Professional Paper 1737-A, p. 8-1-8-28.

Lapham, W.W., Hamilton, P.A., and Myers, D.N., 2005, National Water-Quality Assessment Program-Cycle II regional Assessments of aquifers: U.S. Geological Survey Fact Sheet 2005-3013, 4 p.

Litke, D.W., 2001, Historical water-quality data for the High Plains Regional Groundwater study area in Colorado, Kansas, Nebraska, New Mexico, Oklahoma, South Dakota, Texas, and Wyoming, 1930-98: U.S. Geological Survey Water-Resources Investigations Report, 2000-4254, 65 p.

Maupin, M.A., and Barber, N.L., 2005, Estimated withdrawals from principal aquifers in the United States, 2000: U.S. Geological Survey Circular 1279, 46 p.

McGuire, V.L., 2007, Changes in water levels and storage in the High Plains aquifer, predevelopment to 2005: U.S. Geological Survey Fact Sheet 2007-3029, 2 p.

McGuire, V.L., Johnson, M.R., Schieffer, R.L., Stanton, J.S., Sebree, S.K., and Verstraeten, I.M., 2003, Water in storage and approaches to ground-water management, High Plains aquifer, 2000: U.S. Geological Survey Circular 1243, 51 p.

McMahon, P.B., and Böhlke, J.K., 2006, Regional patterns in the isotopic composition of natural and anthropogenic nitrate in groundwater, High Plains, USA: Environmental Science \& Technology, v. 40, p. 2965-2970.
McMahon, P.B., Böhlke, J.K, and Carney, C.P., 2007, Vertical gradients in water chemistry and age in the northern High Plains aquifer, Nebraska, 2003: U.S. Geological Survey Scientific Investigations Report 2006-5294, 35 p.

McMahon, P.B., Böhlke, J.K., and Christenson, S.C., 2004, Geochemistry, radiocarbon ages, and paleorecharge conditions along a transect in the central High Plains aquifer, southwestern Kansas, USA: Applied Geochemistry, v. 19, p. 1655-1686.

McMahon, P. B., Böhlke, J.K., Kauffman, L.J., Kipp, K.L., Landon, M.K., Crandall, C.A., Burow, K.R., and Brown, C.J., 2008, Source and transport controls on the movement of nitrate to public supply wells in selected principal aquifers of the United States: Water Resources Research, v. 44, W04401, doi:10.1029/2007WR006252.

McMahon, P.B., Böhlke, J.K., and Lehman, T.M., 2004, Vertical gradients in water chemistry and age in the southern High Plains aquifer, Texas, 2002: U.S. Geological Survey Scientific Investigations Report 2004-5053, $53 \mathrm{p}$.

McMahon, P. B., Burow, K.R., Kauffman, L.J., Eberts, S.M., Böhlke, J.K., and Gurdak, J.J., 2008, Simulated response of water quality in public supply wells to land use change: Water Resources Research, v. 44, W00A06, doi:10.1029/2007WR006731.

McMahon, P.B., Dennehy, K.F., Bruce, B.W., Böhlke, J.K., Michel, R.L., Gurdak, J.J., and Hurlbut, D.B., 2006, Storage and transit time of chemicals in thick unsaturated zones under rangeland and irrigated cropland, High Plains, United States: Water Resources Research, v. 42, W03413, doi:10.1029/2005WR004417.

McMahon, P.B., Dennehy, K.F., Bruce, B.W., Gurdak, J.J., and Qi, S.L., 2007, Water-quality assessment of the High Plains aquifer, 1999-2004: U.S. Geological Survey Professional Paper 1749, 136 p.

McMahon, P.B., Dennehy, K.F., Michel, R.L., Sophocleous, M.A., Ellett, K.M., and Hurlbut, D., 2003, Water movement through thick unsaturated zones overlying the central High Plains aquifer, southwestern Kansas, 2000-2001: U.S. Geological Survey Water-Resources Investigations Report 2003-4171, 30 p.

National Land Cover Database, 2001: accessed January 30, 2007, at $h t t p: / / w w w . m r l c . g o v / m r l c 2 k \_n l c d . a s p$

Nolan, B.T., and Stoner, J.D., 2000, Nutrients in groundwaters of the conterminous United States: Environmental Science \& Technology, v. 34, p. 1156-1165. 
Opie, John, 2000, Ogallala-Water for a dry land: Lincoln, University of Nebraska Press, 475 p.

Plummer, L.N., and Friedman, L.C., 1999, Tracing and dating young ground water: U.S. Geological Survey Fact Sheet 134-99, 4 p.

Plummer, L.N., Michel, R.L., Thurman, E.M., and Glynn, P.D., 1993, Environmental tracers for age-dating young groundwater, in Alley, W.M., ed., Regional Groundwater Quality: Van Nostrand Reinhold, New York, p. 255-294.

Pope, L.M., Bruce, B.W., Rasmussen, P.P., and Milligan, C.R., 2002, Quality of shallow ground water in areas of recent residential and commercial development, Wichita, Kansas, 2000: U.S. Geological Survey WaterResources Investigations Report 2002-4228, 75 p.

Qi, S.L., and Gurdak, J.J., 2006, Percentage of probability of nonpoint source nitrate contamination of recently recharged ground water in the High Plains aquifer: U.S. Geological Survey Data Series DS-192, available at http://water.usgs.gov/lookup/getspatial?ds192_hp_npctprob (accessed 01/21/08).

Qi, S.L., Konduris, A., Litke, D.W., and Dupree, J., 2002a, Classification of irrigated land using satellite imagery, the High Plains aquifer, nominal data 1992: U.S. Geological Survey Water-Resources Investigations Report 2002-4236, 31 p.

Qi, S.L., Konduris, A., Litke, D.W., and Dupree, J., 2002b, HPIRRLND_92_Location of irrigated land classified from satellite imagery, High Plains area, nominal date 1992: U.S. Geological Survey Open-File Report 2002-441 (GIS dataset).
Rajagopalan, S., Anderson, T.A., Fahlquist, L., Rainwater, K.A., Ridley, M., and Jackson, W.A., 2006, Widespread presence of naturally occurring perchlorate in High Plains of Texas and New Mexico: Environmental Science \& Technology, v. 40, p. 3156-3162.

Reilly, T.E., Dennehy, K.F., Alley, W.M., and Cunningham, W.L., 2008, Ground Water availability in the United States: U.S. Geological Survey Circular 1323, 70 p., available at http://pubs.usgs.gov/circ/1323/(accessed 01/21/08).

Scanlon, B., 2006, Arsenic contamination in groundwater-online communication: accessed January 15, 2009, at http://www.beg.utexas.edu/environqlty/vadose/arsenic.htm.

Stanton, J.S., and Fahlquist, Lynne, 2006, Ground-water quality beneath irrigated agriculture in the northern and southern High Plains aquifer, Nebraska and Texas, 2003-04: U.S. Geological Survey Scientific Investigations Report 2006-5196, 95 p.

U.S. Environmental Protection Agency, 2009, National primary (and secondary) drinking water standards: accessed January 9, 2009, at http://www.epa.gov/safewater/ mcl.html\#mcls

Whittemore, D.O., 2002, Groundwater recharge in the upper Arkansas river corridor in southwest Kansas: Kansas Geological Survey Open-File Report 2002-30, 29 p.

Wood, W.W., Rainwater, K.A., Thompson, D.B., 1997, Quantifying macropore recharge: examples form a semi-arid area: Groundwater, v. 35, no. 6, p. 1097-1106.

Zogorski, J.S., Carter, J.M., Ivahnenko, T., Lapham, W.W., Moran, M.J., Rowe, B.L., Squillace, P.J., and Toccalino, P.L., 2006, Volatile organic compounds in the Nation's ground water and drinking-water supply wells: U.S. Geological Survey Circular 1292, 101 p. 


\section{Glossary}

(Terms in definitions that are defined elsewhere in the Glossary are shown in boldface within the definition.)

apparent groundwater age The time elapsed since the recharge water became isolated from the atmosphere. The term "age" is normally qualified with the word "apparent" to signify that the accuracy of the determined age is dependant on many variables (Plummer and others, 1993; Plummer and Friedman, 1999)

aquifer A geologic formation, group of formations, or part of a formation that contains sufficient saturated permeable material to yield significant quantities of water to springs and wells.

assimilation A biochemical or abiotic process that uses nitrate or ammonium to form plant proteins and other nitrogencontaining compounds.

biogenic nitrate Nitrate $\left(\mathrm{NO}^{3-}\right)$ that is formed by the process of nitrification in which ammonium is oxidized to nitrate.

chemigation An agricultural practice of injecting chemicals (such as fertilizers) directly into the irrigation water for application of the chemicals through the irrigation system to the crop of field.

confining unit A hydrogeologic unit of impermeable or distinctly less permeable material within an aquifer or bounding one or more aquifers.

degradate A new compound formed by transformation of a pesticide by chemical, photochemical, or biological reactions.

denitrification A microbially facilitated process of nitrate reduction to nitrogen gas $\left(\mathrm{N}_{2}\right)$ through a series of intermediate steps. It is the most important natural sink for nitrate in groundwater.

diffuse recharge A type of recharge that occurs when precipitation or melting snow infiltrates across a uniform area of an aquifer and percolates relatively uniformly through the unsaturated zone, eventually intercepting the water table.

discharge See groundwater discharge.

drawdown The vertical distance the water-table elevation is lowered because of the withdrawal or pumping of groundwater.

focused recharge A type of recharge that occurs by rapid movement of water through the soil and unsaturated zone that bypasses a large portion of the soil and unsaturated-zone matrix.

groundwater Water beneath land surface in the saturated zone.

groundwater age See apparent groundwater age.

groundwater availability A function not only of the quantity and quality of groundwater in an aquifer but also the physical structures, laws, regulations, and socioeconomic factors that control the demand and use of groundwater (Reilly and others, 2008). groundwater discharge Flow of water from the saturated zone.

groundwater recharge The flux of water to groundwater. As used in this report, recharge is the vertical, volumetric flux of water across the water table or saturated zone of an aquifer. Rates of recharge are often expressed in units of length per time $\left(\mathrm{mm} \mathrm{yr}^{-1}\right)$.

groundwater sustainability The amount of groundwater that will be available to support future uses of a particular aquifer or groundwater resource. Alley and others (1999) state that groundwater sustainability is the development and use of groundwater in such a manner that can be maintained for an indefinite time without causing unacceptable environmental, economic, or social consequences.

hydraulic properties Those properties of rock or sediment that govern the entrance of water and the capacity to hold, transmit, and deliver water.

hydrogeologic unit A distinct soil or rock unit or zone which by virtue of its hydraulic properties has a distinct influence on the storage or movement of groundwater.

hydrogeology The geologic and hydrologic features characteristic of a hydrogeologic unit that control the movement of water, solutes, and small particles through the subsurface.

hydrologic system The assemblage of pathways by which water travels as it circulates beneath, at, and above the Earth's surface through various processes such as precipitation, runoff, evaporation, infiltration, transpiration, and groundwater recharge and discharge.

infiltration The process of precipitation or melting snow entering soil or rock across its interface with the atmosphere.

irrigation return flow The part of artificially applied water that is not consumed by evapotranspiration and that migrates to an aquifer or surface-water body.

land-use study The land-use studies are used to measure and explain the quality of recently recharged groundwater in irrigated cropland and urban settings by sampling water-table monitoring wells installed as part of the NAWQA Program.

major-aquifer study The major-aquifer studies are used to broadly assess water-quality conditions in the aquifer by sampling networks of randomly selected, areally distributed existing private wells.

Maximum Contaminant Level (MCL) A drinking-water standard that is legally enforceable and that sets the permissible concentration of a specific compound delivered to any user of a public-water system. In this report, only values established by the U.S. Environmental Protection Agency (USEPA) are used.

milligrams per liter (mg/L) A unit expressing the concentration of chemical constituents in solution as weight (milligrams) of solute per unit volume (liter) of water; equivalent to one part per million in most surface water and groundwater. One thousand micrograms per liter equals $1 \mathrm{mg} / \mathrm{L}$. 
natural attenuation The reduction in constituent concentration in the environment that is caused by naturally occurring physical, chemical, and (or) biological processes.

nonpoint sources A diffuse and widely dispersed location at which one or more contaminants are known to be released into the hydrologic system, such as agricultural runoff or atmospheric deposition.

pesticide A chemical applied to crops, rights-of-way, lawns, or residences to control weeds, insects, fungi, nematodes, rodents, and other "pests."

point source A specific location at which one or more contaminants are known to be released into the hydrologic system.

predevelopment The time prior to substantial groundwater development for irrigation. McGuire and others (2003) estimate that 1957 was the median year defining predevelopment across the High Plains.

public-supply well A privately or publicly owned well that provides water for public use to: (A) community water systems, (B) transient noncommunity water systems, such as campgrounds, or (C) nontransient, noncommunity systems, such as schools.

recently recharged groundwater In this report, refers to groundwater that was recharged during the past approximate 50 years, as indicated by tritium concentrations in groundwater greater than 0.5 tritium unit.

recharge See groundwater recharge.

reduction-oxidation (redox) Chemical reactions that involve a change in the oxidation number (state) of atoms. Redox processes in groundwater often are microbially facilitated.

regional-transect study The regional-transect studies are used to characterize vertical gradients in groundwater chemistry and apparent groundwater age in the thickest areas of the High Plains aquifer and to identify major biogeochemical reactions affecting the quality of water along groundwater flow paths leading from recharge areas to down gradient wells. saturated zone The subsurface region in the aquifer in which all the interstices or voids are filled with water under a pressure equal to or exceeding that of the atmosphere.

Secondary Maximum Contaminant Level (SMCL) A drinkingwater guideline that is not legally enforceable for "secondary" contaminants, which is set by the U.S. Environmental Protection Agency (USEPA). A secondary contaminant is a concern for the esthetic qualities of drinking water.

sodium adsorption ratio (SAR) A measure of irrigation water sodium hazard. It is the ratio of sodium to calcium plus magnesium adjusted for valence. The SAR value of water is considered along with specific conductance in determining suitability for irrigation.

Study Unit A major hydrologic system of the United States, geographically defined by surface-water or groundwater features, in which NAWQA sampling studies are focused.

subsurface The region of material beneath the land surface that encompasses the soil, unsaturated, and saturated zones.

transit time The time required for water or a chemical to travel between two locations.

tritium unit (TU) A measure of the concentration of tritium $\left({ }^{3} \mathrm{H}\right)$, equal to $1{ }^{3} \mathrm{H}$ atom in $10^{18}$ atoms of hydrogen $(\mathrm{H})$, or 3.24 picocuries per liter $(\mathrm{pCi} / \mathrm{L})$.

unsaturated zone The subsurface zone between land surface and the water table, characterized as containing water under pressure less than that of the atmosphere. The matrix of the unsaturated zone is not completely filled with water; thus, gases exist in the pore spaces of the unsaturated zone.

unsaturated-zone study The unsaturated-zone studies are used to measure the amount of chemicals stored in the subsoil above the water table of the High Plains aquifer and determine their transit times from land surface to the water table in rangeland and irrigated settings.

water table The point below land surface at which groundwater is first present and below which the aquifer material is saturated. 


\title{
Appendix 1
}

\author{
Abbreviations and Acronyms \\ $\delta \quad$ delta value of an isotopic composition \\ $\mathrm{km} \quad$ kilometer \\ LOWESS locally weighted scatterplot smoothing \\ $\mathrm{mg} / \mathrm{L} \quad$ milligrams per liter \\ MCL Maximum Contaminant Level \\ $\mathrm{N} \quad$ nitrogen \\ NAWQA U.S. Geological Survey National Water-Quality Assessment Program \\ $\mathrm{NO}_{3}^{-} \quad$ nitrate \\ SAR Sodium adsorption ratio \\ SDWA Safe Drinking Water Act \\ SMCL Secondary Maximum Contaminant Level \\ TU tritium unit \\ $\mu \mathrm{g} / \mathrm{L} \quad$ micrograms per liter \\ USEPA U.S. Environmental Protection Agency \\ USGS U.S. Geological Survey \\ VOC volatile organic compound
}




\section{Appendix 2}

\section{Study-Unit Design}

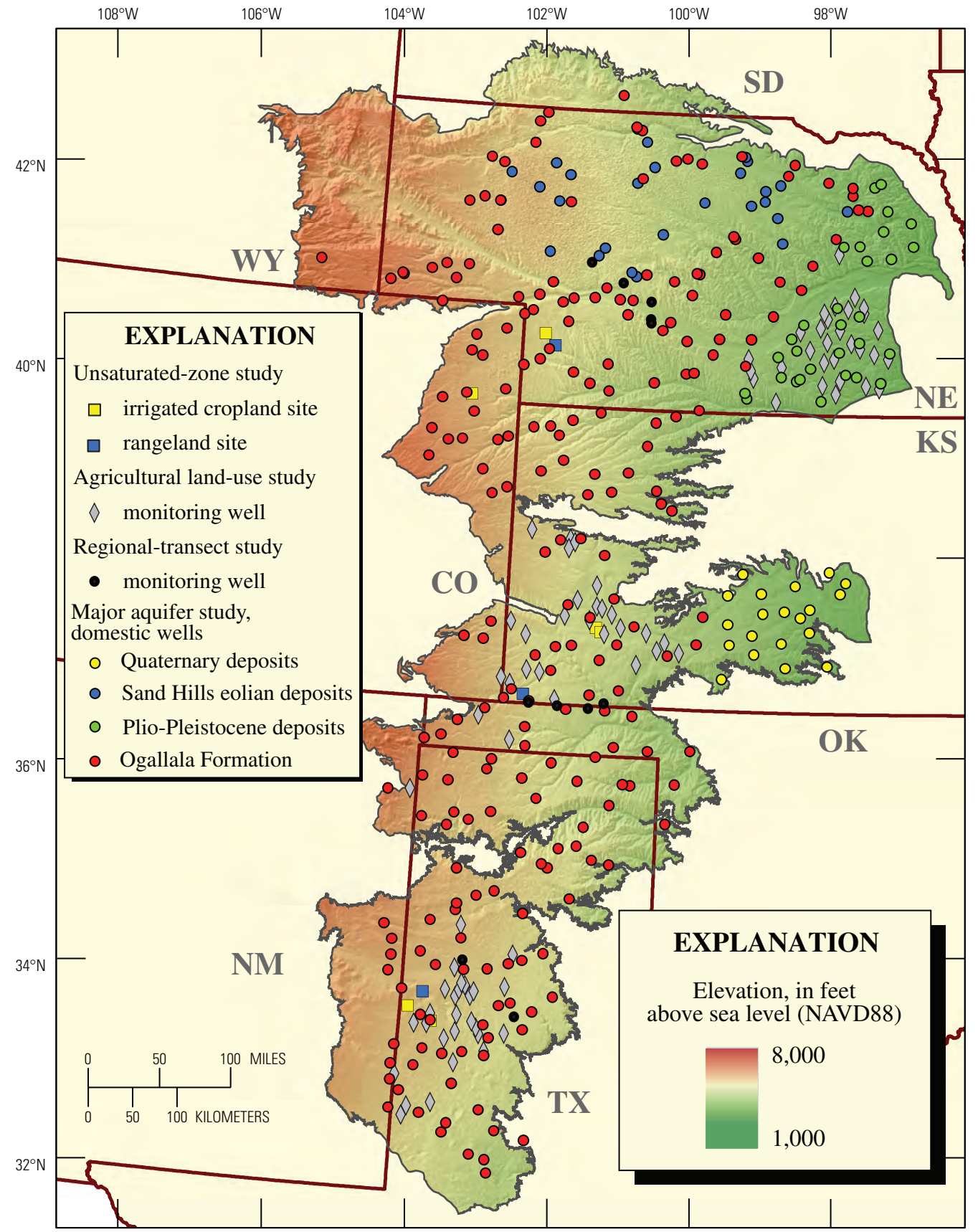

Base information from U.S. Geological Survey digital data, 1:100,000

Albers Equal-Area projection

Standard Parallels $29^{\circ} 30^{\prime}$ and $45^{\circ} 30^{\prime}$, central meridian $-96^{\circ}$

Figure A2-A. Location of all sampled wells. 


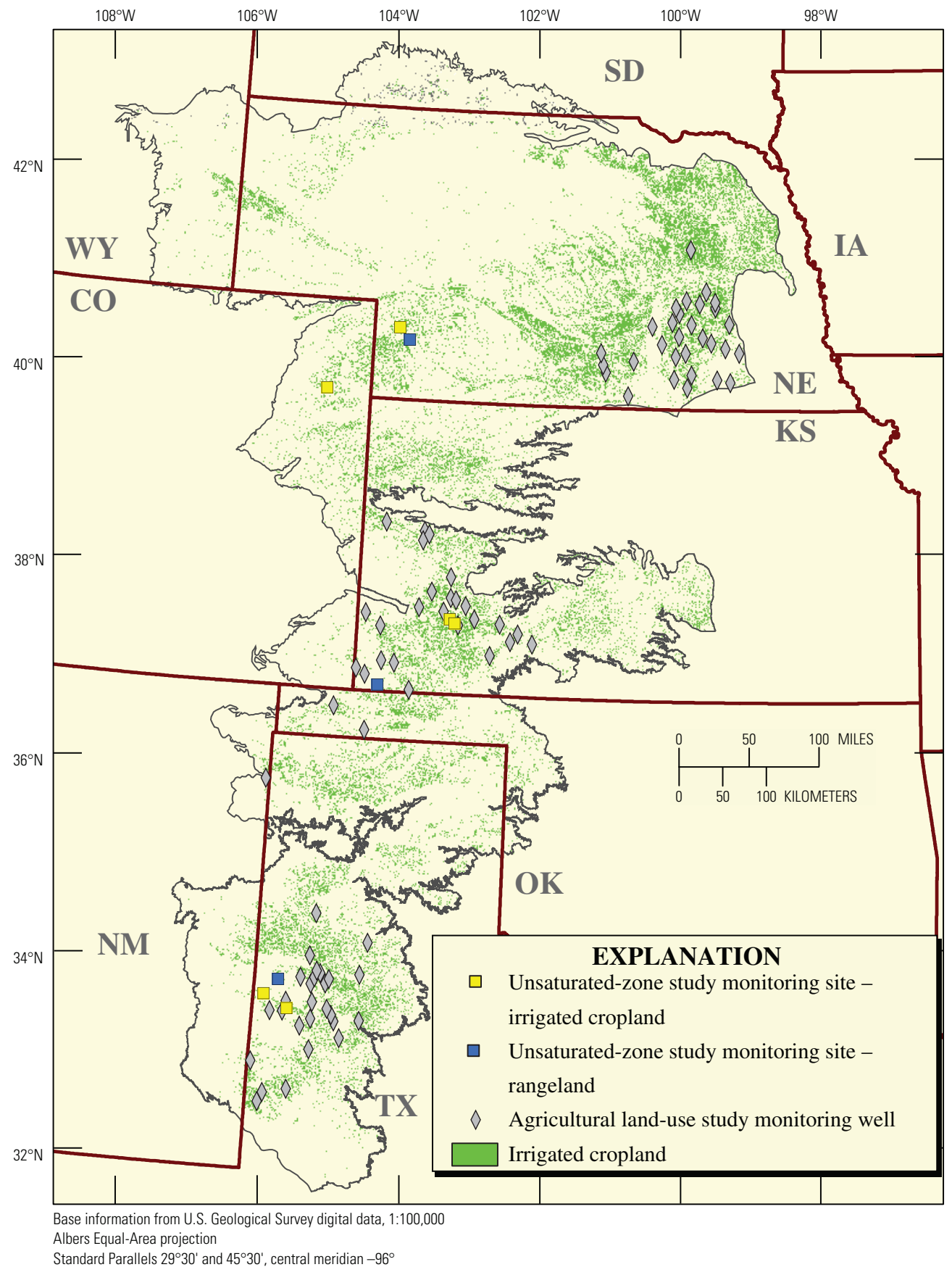

Figure A2-B. Location of unsaturated-zone study monitoring wells, agricultural land-use study monitoring wells, and distribution of irrigated cropland in the High Plains aquifer area, nominal date 1992 (Qi and others, 2002a). 


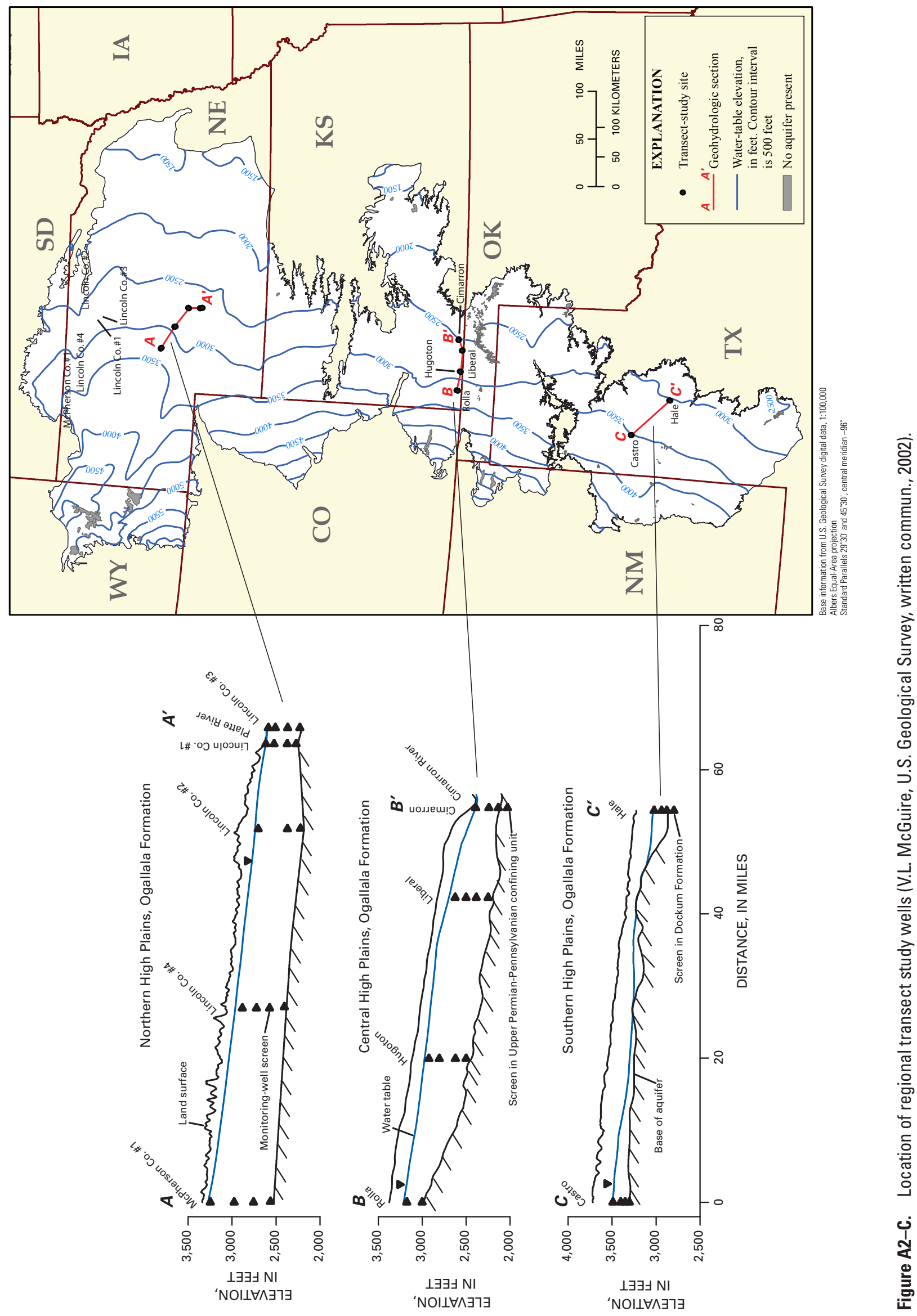




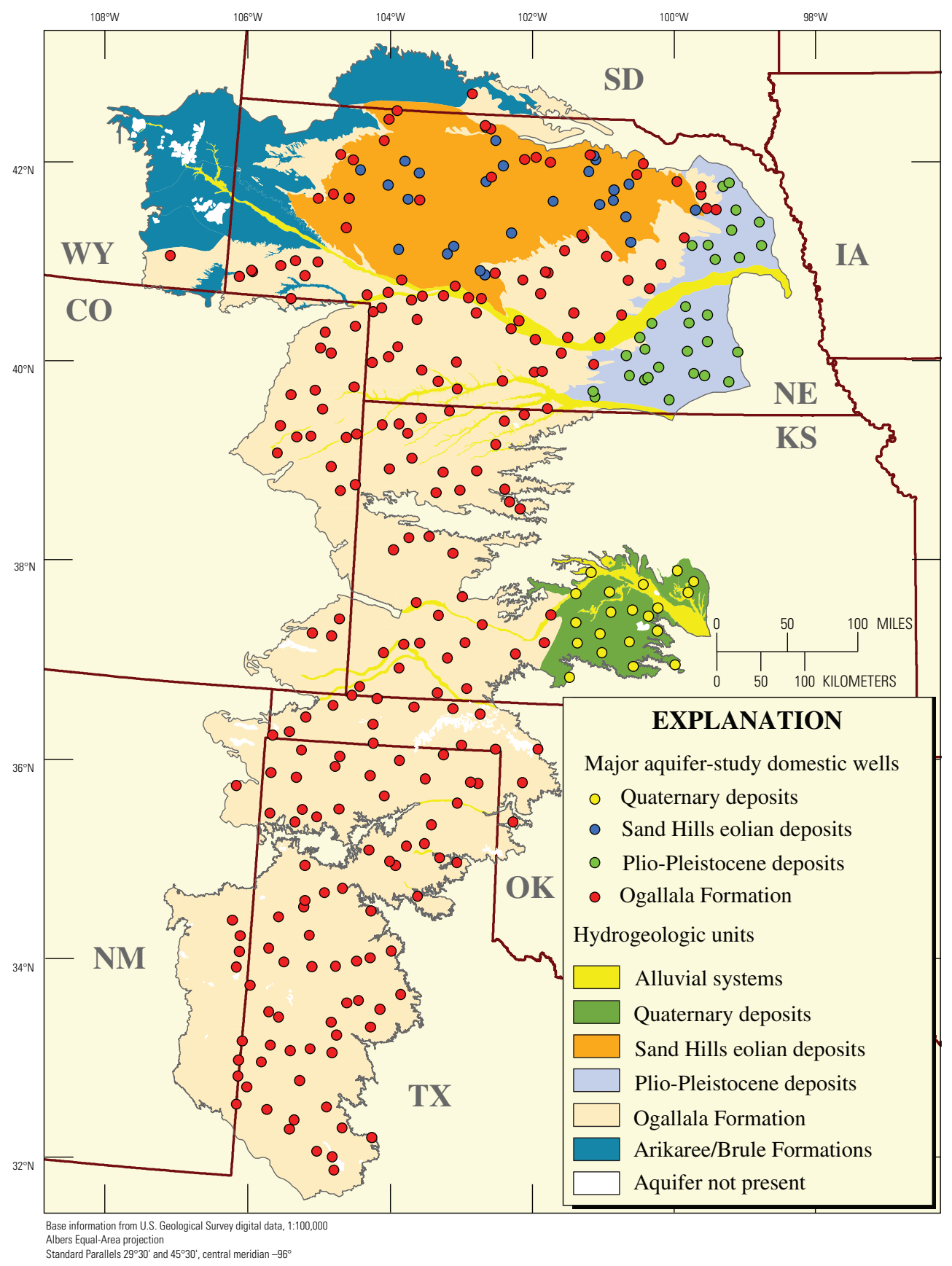

Figure A2-D. Location of major aquifer-study wells and distribution of hydrogeologic units 


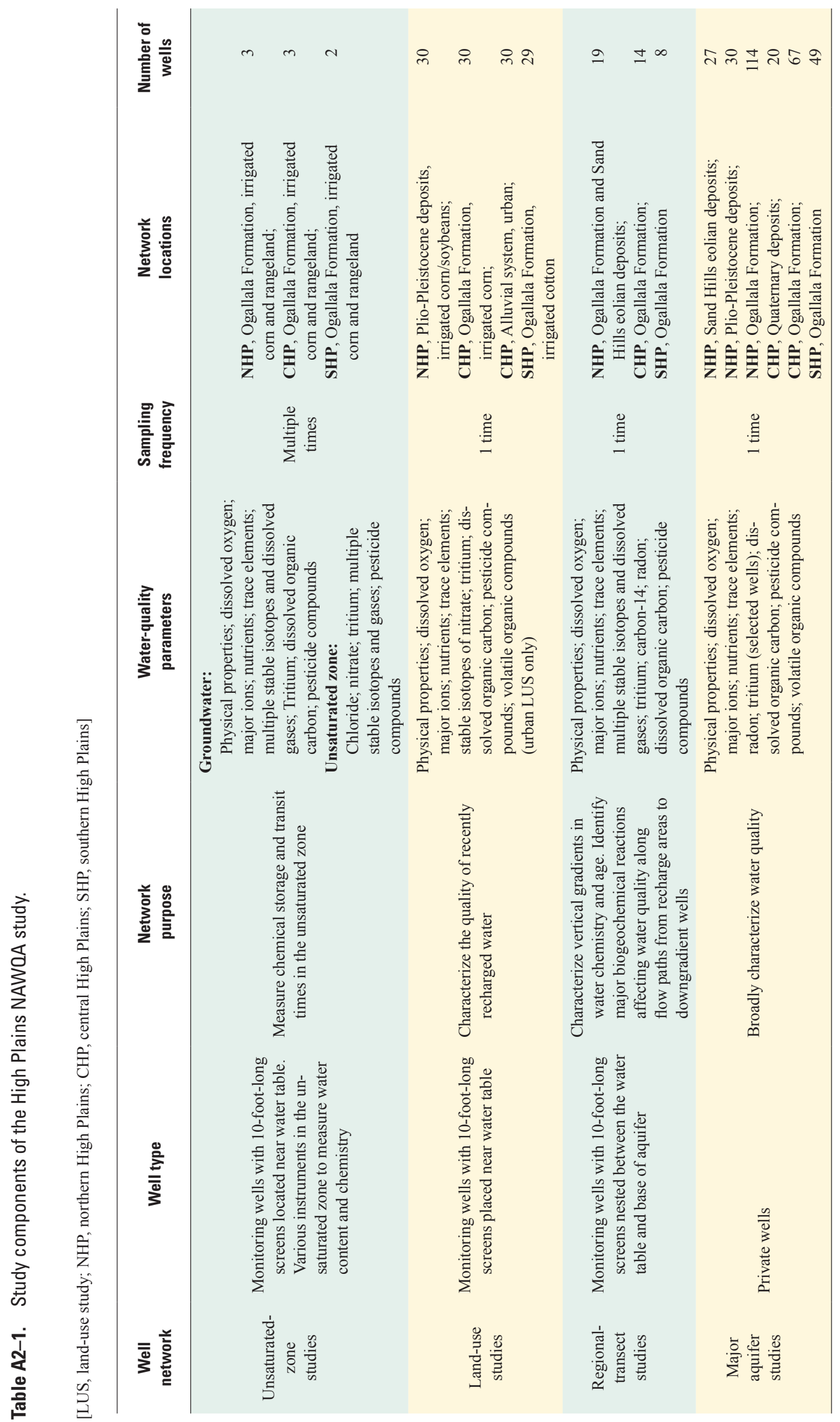




\section{Appendix 3}

\section{High Plains Findings in a National Context}

This appendix includes graphical comparisons of chemical concentrations for some of the most commonly detected inorganic and organic constituents in the High Plains aquifer and other principal aquifers of the United States (Nolan and Stoner, 2000; Lapham and others, 2005; Gilliom and others, 2006; Zogorski and others, 2006). For each constituent, the concentration data are grouped according to four well types: shallow agricultural monitoring wells (agricultural land-use study wells), private wells (major-aquifer study wells), shallow urban monitoring wells (urban land-use study wells), and public-supply wells. For each well type, the aquifers also are grouped according to aquifer lithology: basalt and volcanics, carbonate/crystalline, carbonate/sandstone, sand and gravel, and semiconsolidated sand. For organic compounds, graphs show only concentrations detected above a common assessment level, and data for a particular compound were not plotted if there were fewer than five detections of the compound. Note that analytical detection limits varied among the constituents; thus, detection frequencies are not comparable between constituents. For a given constituent, however, detection frequencies are comparable between aquifers. The data used in this report for the High Plains aquifer are available at URL: http://co.water.usgs.gov/nawqa/hpgw/index.html (accessed January 13, 2009).

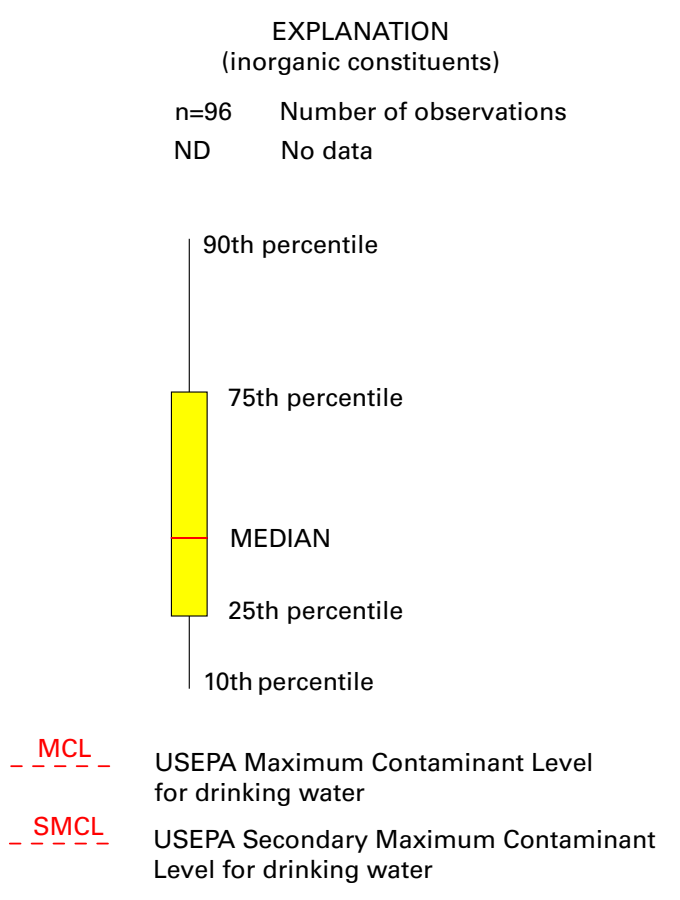

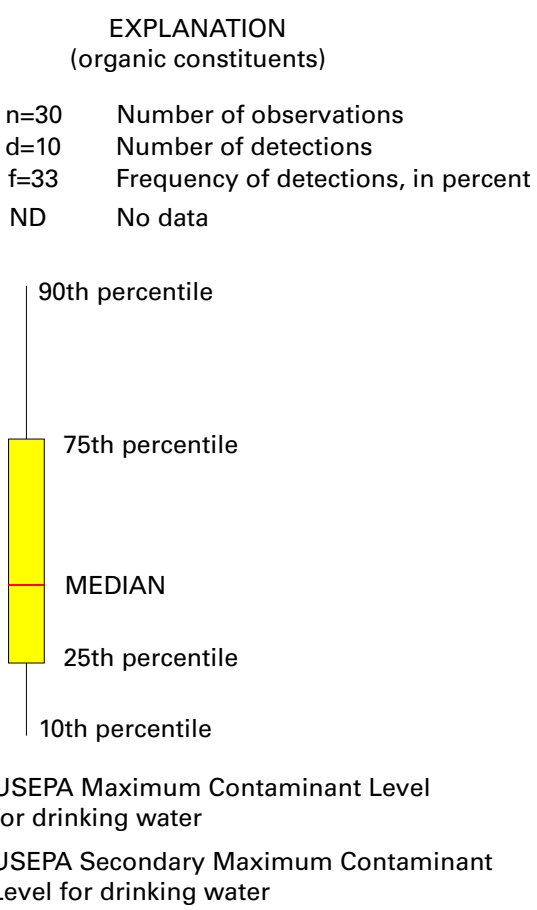



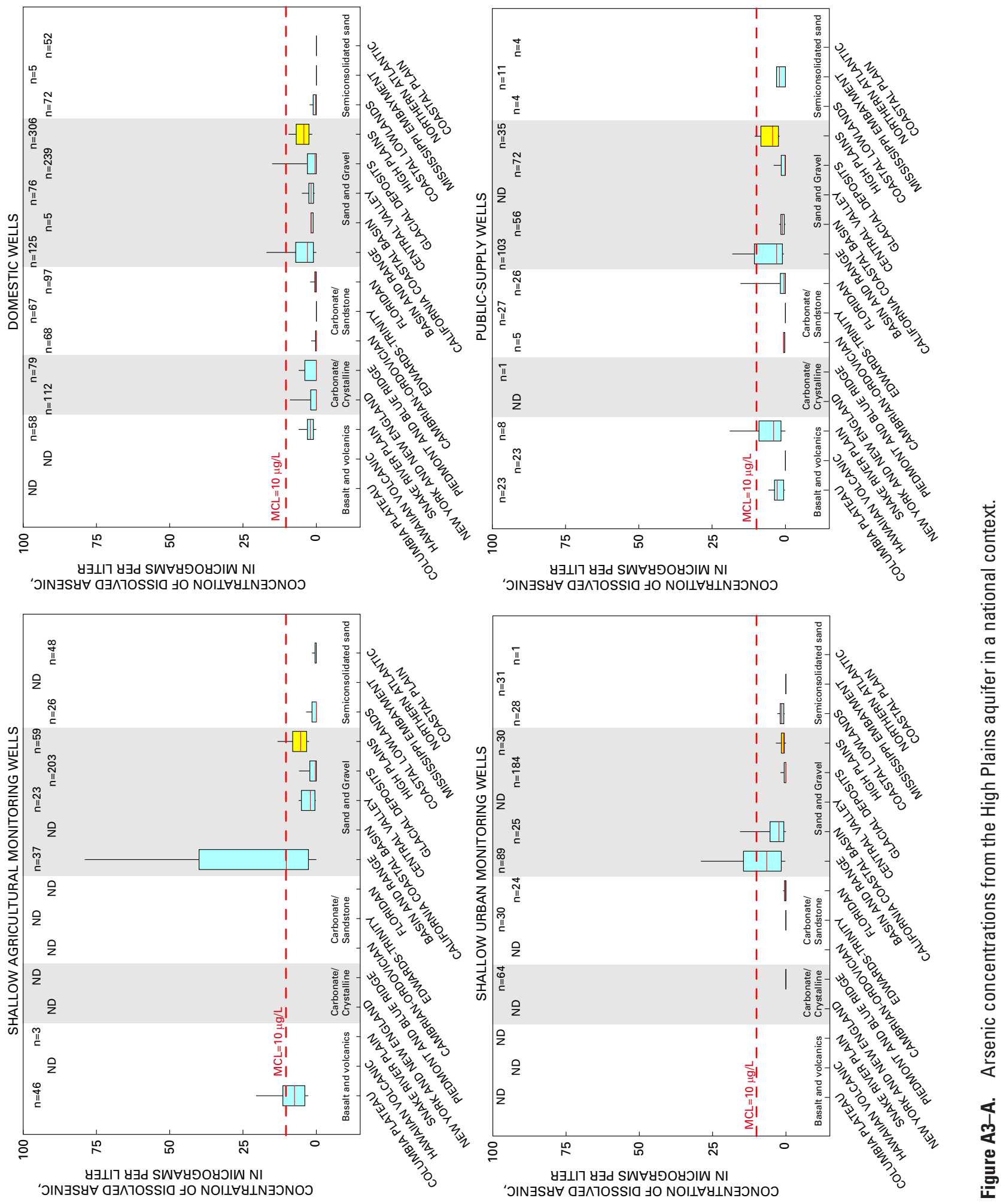

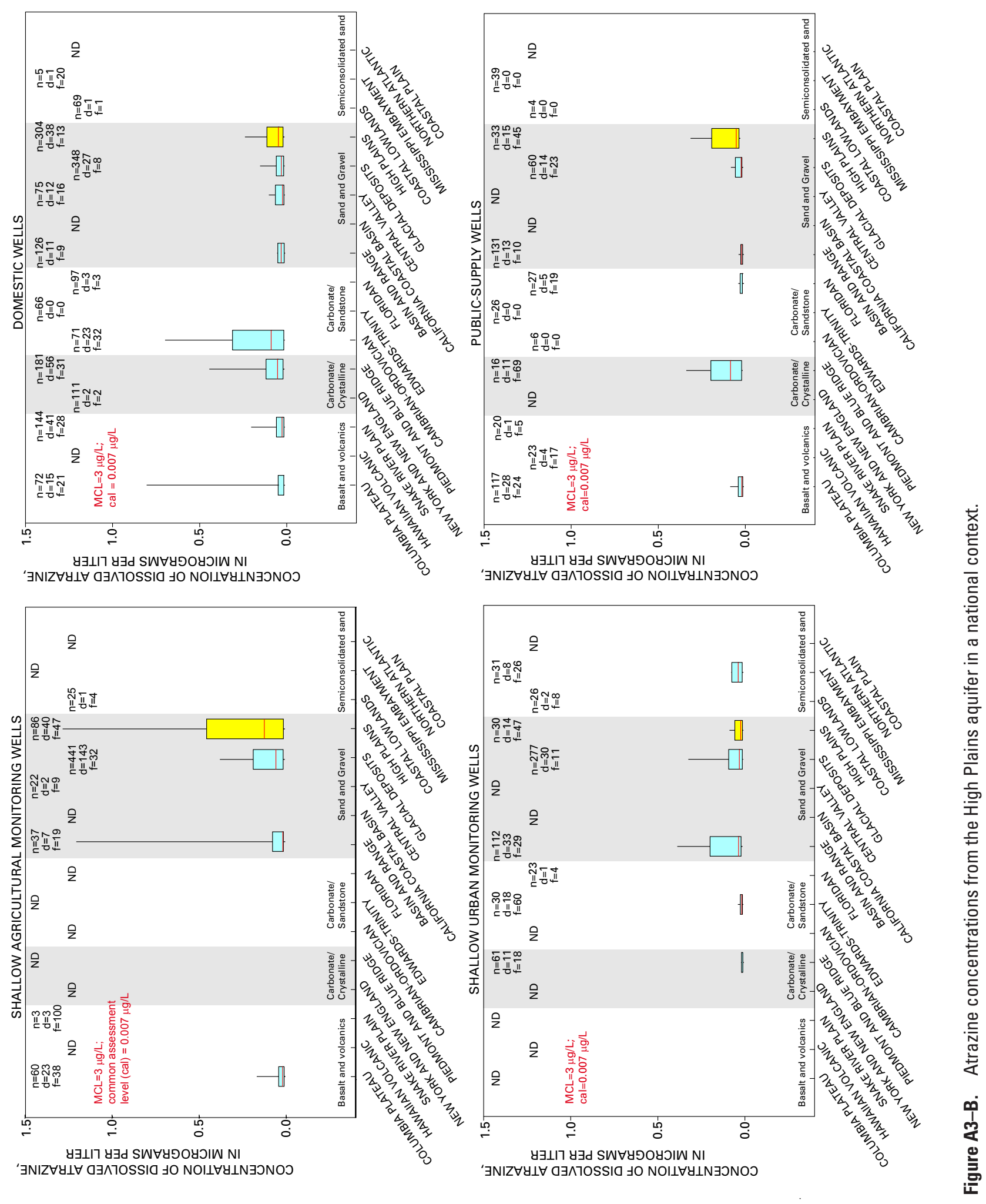

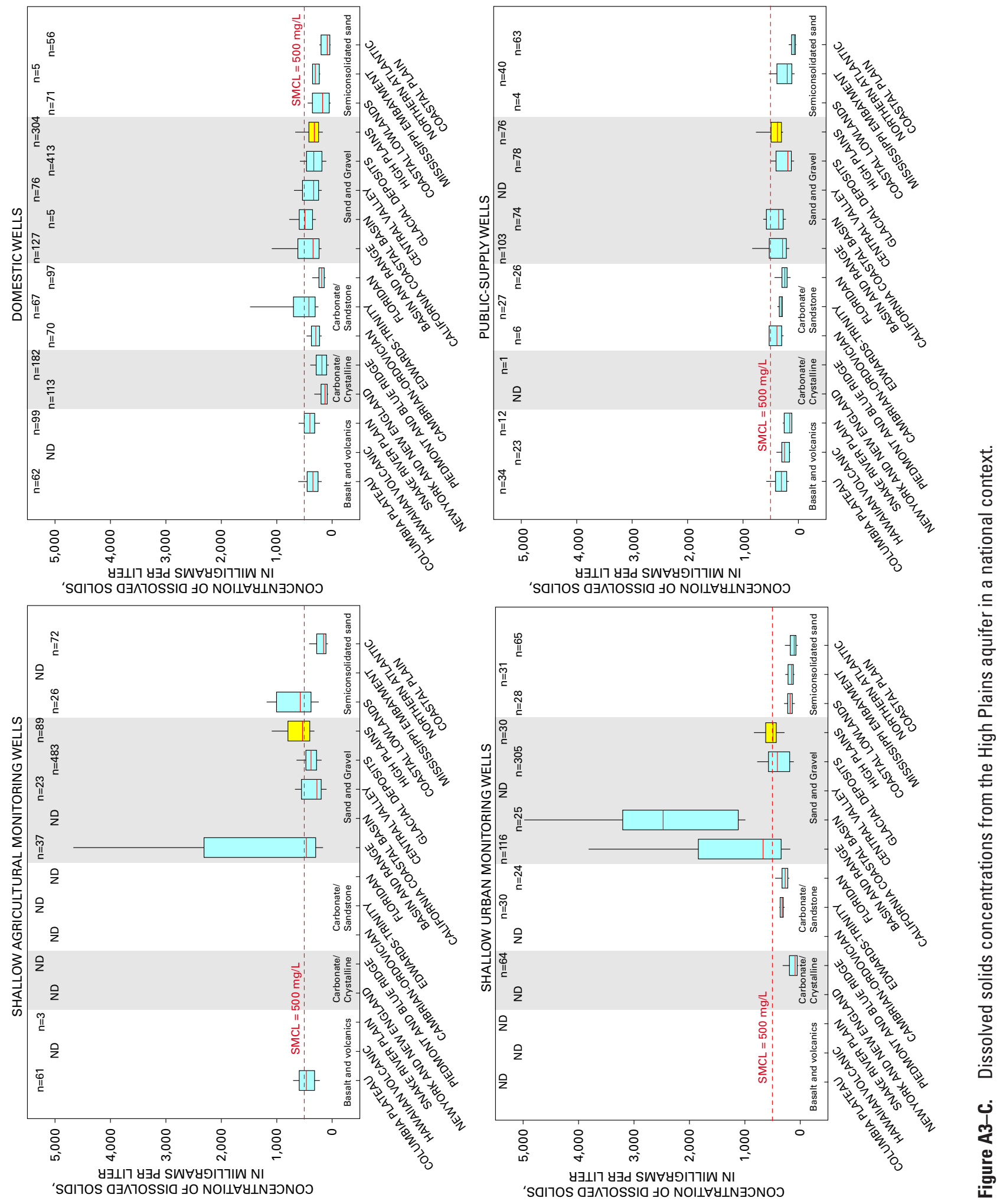

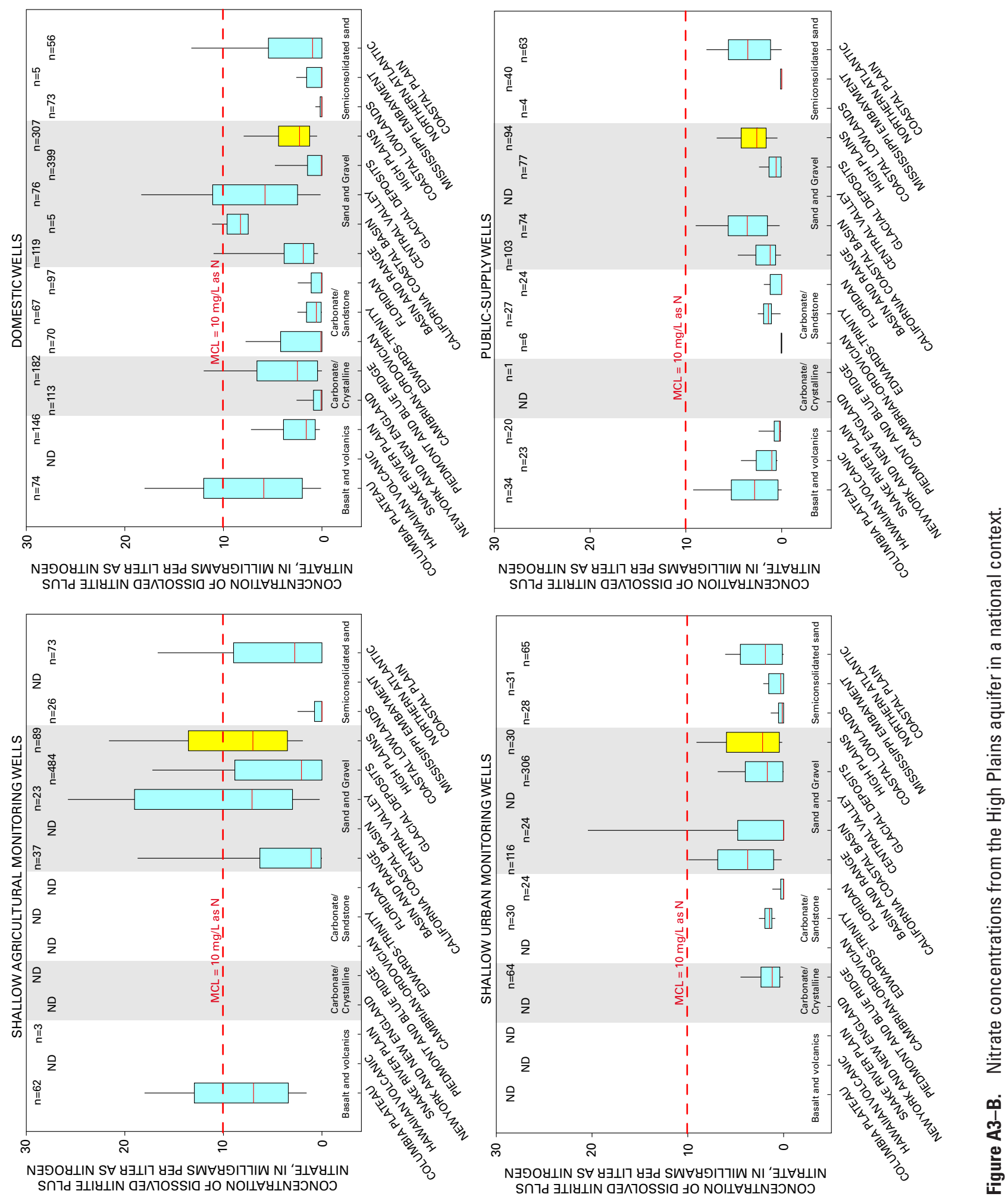


\section{Acknowledgments}

The cooperation of landowners who agreed to the installation and long-term operation of monitoring wells on their property and owners of private and public-supply wells for allowing access is gratefully acknowledged. Coordination and scientific collaboration with agencies and organizations in the High Plains were integral to the success of this water-quality assessment. We thank those who served as members of our liaison committee:

- Colorado Department of Agriculture (Daniel Hurlbut)

- Kansas Geological Survey (Marios Sophocleous and Margaret Townsend)

- Texas Bureau of Economic Geology (Bridget Scanlon and Robert Reedy)

- Nebraska Conservation and Survey Division (Jim Goeke)

- Nebraska Cooperative Hydrology Study (Clint Carney)
We thank the following individuals within the USGS for contributing to this study. Personnel from several USGS offices were instrumental in providing guidance and scientific and field support during the 6-year field effort:

- Bret Bruce (USGS Regional Executive's Office, Rocky Mountain Area),

- Larry (Mike) Pope and Cristi Hansen (USGS Kansas Water Science Center),

- Jennifer Stanton and Virginia (Ginny) McGuire (USGS Nebraska Water Science Center),

- Mark Becker and Scott Christenson (USGS Oklahoma Water Science Center),

- Lynn Fahlquist (USGS Texas Water Science Center),

- the USGS Central Region Drilling Team, and

- Kevin Ellett (USGS California Water Science Center).

Amber Swallow prepared the block-diagram figures of the High Plains aquifer. Tracy Hancock (USGS, Virginia Water Science Center), Suzanne Paschke (USGS, Colorado Water Science Center), Gary Rowe (USGS, Central Region), Mike Woodside (USGS, Eastern Region), Pixie Hamilton (USGS), and Wayne Lapham (USGS) provided constructive reviews of earlier versions of this report. 
Publishing support provided by:

Denver Publishing Service Center

For more information concerning this publication, contact:

Director, USGS Colorado Water Science Center

Box 25046, Mail Stop 415

Denver, CO 80225

(303) 236-4882

Or visit the Colorado Water Science Center Web site at: http://co.water.usgs.gov/ 